Stralberg, D., D. Berteaux, C. Drever, M. Drever, I. Naujokaitis-Lewis, F. K. A. Schmiegelow, and J. A. Tremblay. 2019. Conservation planning for boreal birds in a changing climate: a framework for action. Avian Conservation and Ecology 14(1):13. https://doi.org/10.5751/ACE-01363-140113 Copyright (C) 2019 by the author(s). Published here under license by the Resilience Alliance.

Essay, part of a Special Feature on Conservation of Boreal Birds

\title{
Conservation planning for boreal birds in a changing climate: a framework for action
}

\author{
Diana Stralberg ${ }^{1,2}$, Dominique Berteaux ${ }^{3}$, C. Ronnie Drever ${ }^{4}$, Mark Drever $^{5}$, Ilona Naujokaitis-Lewis ${ }^{6}$, Fiona K. A. Schmiegelow $^{1,2,7}$ \\ and Junior A. Tremblay, ${ }^{1,8}$ \\ ${ }^{1}$ Boreal Avian Modelling Project, ${ }^{2}$ Department of Renewable Resources, University of Alberta, Edmonton, AB, Canada, ${ }^{3}$ Centre \\ d'études nordiques and Centre de la science de la biodiversité du Québec, Université du Québec à Rimouski, Rimouski, QC, \\ Canada, ${ }^{4}$ Nature United, Ottawa, ON, Canada, ${ }^{5}$ Pacific Wildlife Research Centre, Environment and Climate Change Canada, \\ Delta, BC, Canada, ${ }^{6}$ Landscape Science and Technology Division, National Wildlife Research Centre, Environment and Climate \\ Change Canada, Ottawa, ON, Canada, ${ }^{7}$ Northern ENCS Program, Yukon College, Whitehorse, YT, Canada, ${ }^{8}$ Wildlife Research \\ Division, Environment and Climate Change Canada, Québec, QC, Canada
}

\begin{abstract}
The boreal forests of North America support billions of birds of over 300 species. The region remains mostly intact but is expected to undergo major changes over the next century due to anthropogenic climate change. This warming, and resulting changes in moisture regimes, are altering vegetation and disturbance dynamics, and will likely result in expansion of grasslands and deciduous forests, strongly challenging bird species to keep pace. We present a vulnerability-adaptation framework to guide bird conservation based on species' individual vulnerability and exposure to climate change. For sensitive species with declining populations, conservation should focus on management of current threats and species recovery in situ to improve adaptive capacity and facilitate future shifts in distribution. Sensitive species with high exposure to climate change may warrant more extensive intervention, such as habitat manipulation or even translocation. For species with lower sensitivity and stable populations, but high climate change exposure, longterm investments in protecting refugia and "stepping stones" will be most effective. In general, across all species, land-based approaches that "conserve nature's stage" by promoting geophysical diversity and habitat connectivity, maintaining natural disturbance dynamics, and facilitating broad shifts in bird distribution may prove most effective in maintaining species diversity. Implementation of this framework will require large-scale, interagency coordination on recovery plans, as well as adaptive forest management, designation of critical habitat, and land protection. Challenges include data gaps, uncertainty about future conditions, coordination of conservation actions during the nonbreeding periods, and the region's vast scale. However, given the region's continental importance, successful implementation of this framework could benefit birds throughout the western hemisphere.
\end{abstract}

\section{Planification de la conservation des oiseaux de la forêt boréale dans un climat en évolution : un cadre d'action}

RÉSUMÉ. Les forêts boréales d'Amérique du Nord abritent des milliards d'oiseaux de plus de 300 espèces. La région reste en grande partie intacte mais devrait subir d'importants changements au cours du prochain siècle en raison du changement climatique anthropique. Ce réchauffement, et les changements de régimes d'humidité qui en résultent, modifient la dynamique de la végétation et des perturbations, ce qui entraînera probablement une expansion des prairies et des forêts de feuillus, ce qui compliquera fortement la donne pour les espèces d'oiseaux concernées. Nous présentons un cadre d'adaptation à la vulnérabilité pour guider la conservation des oiseaux en fonction de la vulnérabilité individuelle de chaque espèce et de son exposition aux changements climatiques. Pour les espèces sensibles dont les populations sont en déclin, la conservation devrait être axée sur la gestion des menaces actuelles et le rétablissement des espèces in situ afin d'améliorer la capacité d'adaptation et de faciliter les futurs changements de répartition. Les espèces sensibles fortement exposées aux changements climatiques peuvent nécessiter des interventions plus poussées, telle que la manipulation de l'habitat ou même la translocation. Pour les espèces moins sensibles et les populations stables, mais tout de même exposées aux changements climatiques, des investissements à long terme pour protéger les refuges et les « tremplins » seront plus efficaces. En général, pour toutes les espèces, les approches terrestres qui «préservent la nature en l'état»en favorisant la diversité géophysique et la connectivité de l'habitat, en maintenant la dynamique des perturbations naturelles et en facilitant de grands changements dans la répartition des oiseaux peuvent s'avérer plus efficaces pour maintenir la diversité des espèces. La mise en oeuvre de ce cadre nécessitera une coordination interinstitutionnelle à grande échelle sur des plans de rétablissement, ainsi que la gestion des forêts adaptative, la désignation d'habitats essentiels et la protection des terres. Les défis comprennent des lacunes dans les données, comme l'incertitude quant aux conditions futures, la coordination des mesures de conservation en dehors de la période de reproduction et la vaste étendue de la région. Cependant, étant donné l'importance de la région à l'échelle continentale, la réussite de la mise en oeuvre de ce cadre pourrait profiter aux oiseaux de tout l'hémisphère occidental.

Key Words: boreal; climate change; climate exposure; conservation; refugia; vulnerability 


\section{INTRODUCTION}

The approximately 600 million ha North American boreal region represents $25 \%$ of the intact forest landscapes remaining globally (Lee et al. 2006, Potapov et al. 2017). Referred to as North America's "bird nursery," the boreal region supports over 300 regularly breeding bird species, and is estimated to provide more than half of the overall breeding habitat for 96 North American bird species and over $80 \%$ of breeding habitat for 35 of these (Wells and Blancher 2011). Boreal wetlands provide migratory stopover or breeding habitat for approximately 7 million shorebirds, representing 19 species, and 26 million waterfowl, representing 35 species (Slattery et al. 2011, Wells and Blancher 2011). While development pressures are increasing, especially in the southern portion, the North American boreal biome remains relatively unfragmented compared to other major forests around the world (Lee et al. 2006, Potapov et al. 2017), with only approximately $5 \%$ of Canada's boreal region directly disturbed by human activity (Pasher et al. 2013) and an even smaller proportion in Alaska (United States).

The conservation and socioeconomic importance of boreal birds is well recognized. Many efforts exist to quantify existing threats to bird abundance and distribution, mostly relating to direct habitat disturbance and fragmentation (e.g., Schmiegelow et al. 1997, Drapeau et al. 2000, Hobson et al. 2013, Bayne et al. 2016). However, anthropogenic climate change presents new challenges for biologists and managers. In this paper, we summarize projected impacts of climate change in the boreal region of North America, with an overview of projected responses and potential vulnerabilities of boreal birds to climate change. We then present a conceptual framework for advancing boreal bird conservation based on each species' vulnerability to changing climate, summarize key strategies for climate-smart boreal bird conservation, and provide suggestions for addressing climatechange related conservation challenges.

\section{THE CHANGING BOREAL CLIMATE}

Boreal climates are characterized by long, cold winters and short, cool summers (Brandt et al. 2013). Although average annual precipitation is low, moisture is retained because of cold temperatures and minimal evapotranspiration, thereby maintaining large wetland complexes and coniferous forests. Climates within the current boreal biome are projected to undergo significant changes in the future, with an average warming of $2^{\circ}$ C expected from 2000 to 2050 (Price et al. 2013, Gauthier et al. 2015), and up to $4-5^{\circ} \mathrm{C}$ by the end of the 21 st century if global anthropogenic greenhouse gas emissions are not controlled (Price et al. 2013). This warming will translate into a longer growing season, with an expected increase of more than 400 growing degree days by the end of the 21 st century in the western boreal plains (Pacific Climate Impacts Consortium, https:// pacificclimate.org/analysis-tools/plan2adapt). Warmer temperatures will be accompanied by increases in annual precipitation (Meehl et al. 2007), but also decreases in available moisture (Hogg and Bernier 2005), with substantial differences between western and eastern regions (Boulanger et al. 2017). In western regions, increased precipitation will be offset by higher evapotranspiration rates. Longer and more severe droughts will likely result in serious tree-killing events that may ultimately transform closed boreal forests into open woodlands (Scheffer et al. 2012). In eastern forests, where moisture is less limiting, conversion to more productive temperate forests may occur as critical temperature isoclines shift northward (Price et al. 2013).

In upcoming decades, warmer temperatures and increased drought will likely result in more frequent disturbance events from large wildfires (Boulanger et al. 2014) and population outbreaks of bark beetles and defoliators (Price et al. 2013), although with significant uncertainty as to magnitude (Boulanger et al. 2016). Throughout the boreal region, a disturbance-mediated competitive shift from mid- to late-successional coniferous species, such as white spruce (Picea glauca) and balsam fir (Abies balsamifera), to deciduous species such as trembling aspen (Populus tremuloides), oak (Quercus spp.), and maple (Acer spp.) is expected (Boulanger et al. 2017). Thawing of permafrost may temporarily convert low-lying sections of boreal regions from forest-wetland mosaics to sparsely treed, permafrost-free wetlands (Baltzer et al. 2014). Declining water tables are likely to alter nonpermafrost wetland landscapes (Thompson et al. 2017), although negative feedbacks that retain moisture during dry periods may result in peatland systems persisting well beyond climatically suitable conditions (Waddington et al. 2015).

Ecosystem changes are likely to be rapid and dramatic in the boreal biome compared to other regions of the world. Climate velocity - the speed at which species and ecosystems must migrate to keep pace with climate change (Loarie et al. 2009) - is particularly high, because of a combination of relatively flat topography and higher rates of warming in the north (Hamann et al. 2014). Over the long term, assuming eventual equilibrium between climate and vegetation, the North American boreal biome is projected to both shift northward (Rowland et al. 2016) and to shrink in size by an estimated $14-42 \%$ by the end of the 21st century (Appendix 1, Fig. 1; see also Rehfeldt et al. 2012). In the short term, however, this rapid change means that the majority of the present boreal biome will be in a state of disequilibrium between climate and biota. These changes will occur in the presence of ongoing industrial development, including extensive forestry across the southern half of the boreal region, widespread oil and gas exploration in the western sedimentary basin, large-scale hydroelectric projects, and mineral extraction projects throughout the biome (Brandt et al. 2013). Thus, combined increases in human and climate-induced disturbance are likely to further reduce the extent and connectivity of boreal forest ecosystems.

\section{BOREAL BIRD VULNERABILITY TO CLIMATE CHANGE}

As with other species, boreal bird distributions are generally projected to shift northward and upslope with climate change (Rodenhouse et al. 2008, Ralston and Kirchman 2013, Marcot et al. 2015, Stralberg et al. 2015a). Although historical distributional shifts have not been documented for many boreal bird species in North America (but see McClure et al. 2012, DeLuca and King 2017), research from Fennoscandia indicates northward shifts in species richness (Virkkala and Lehikoinen 2014) and pronounced range contractions in long-distance migrants in particular (Virkkala et al. 2018). A warmer climate may enable the immigration of new species from southern grasslands and eastern deciduous forests into the current boreal region, ultimately 
resulting in a northward shift in species richness patterns (Berteaux et al. 2010, Langham et al. 2015, Nixon et al. 2016). However, most current boreal-breeding species will face substantial declines in suitable habitat by the end of the century because the northward expansion of forested habitats will not compensate for anticipated conversion of coniferous forest to deciduous woodland and grassland in the south (Stralberg et al. 2015a).

Fig. 1. Model-predicted (a) baseline (1961-1990), (b) midcentury (2041-2070), and (c) end-of-century (2071-2100) changes in boreal ecoregions for an ensemble of 15 global climate models under representative concentration pathway (RCP) 8.5. Boreal, hemi-boreal, and western forested regions are shown in green and blue-green shades; arctic ecoregions are in blue shades; prairie/parkland ecoregions are in brown shades; and temperate forest ecoregions are in yellow and orange shades. Boreal ecoregions are also outlined in black. See Appendix 1 for detailed methods and results for all North American ecoregions.

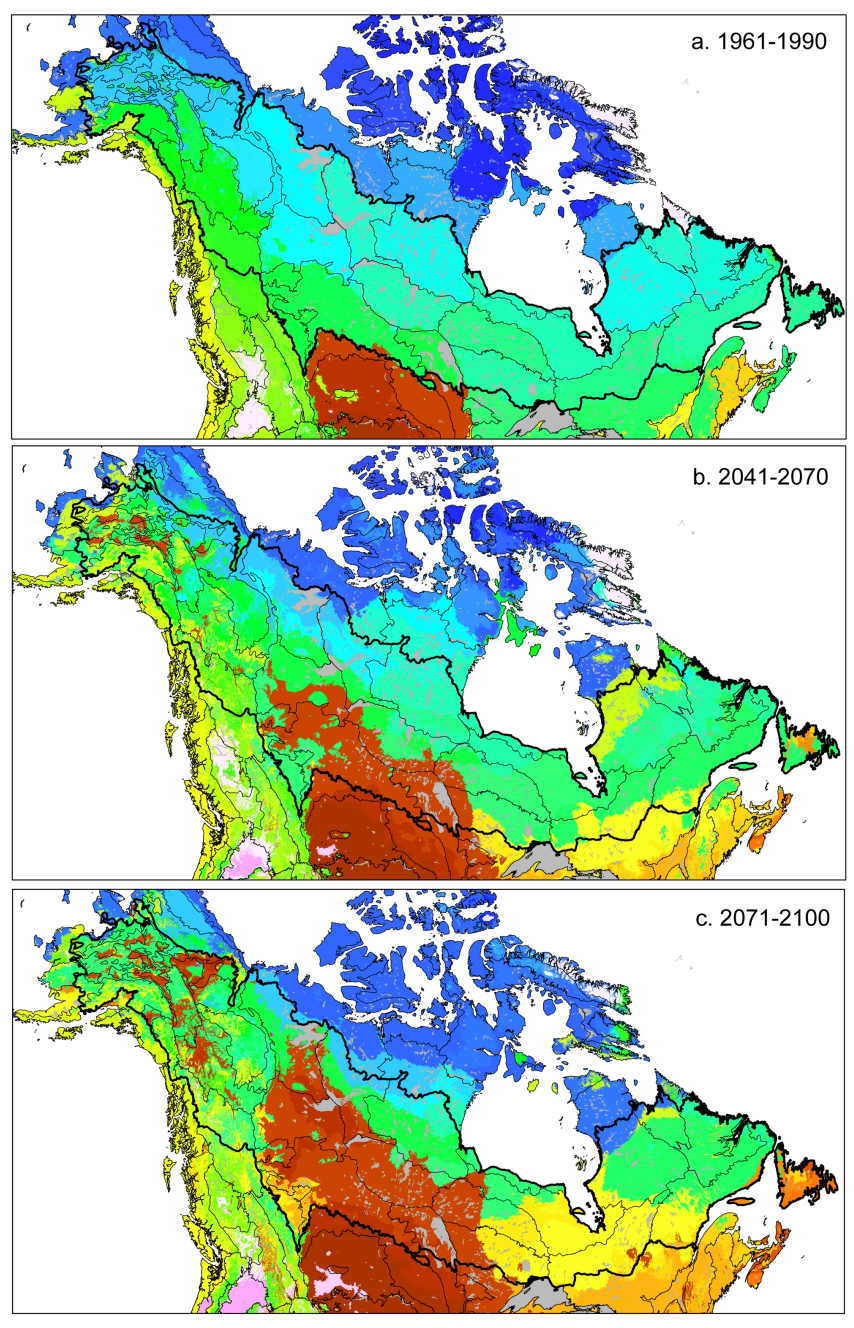

In light of these anticipated changes in habitat, all boreal bird species will be affected in some way by climate change. Understanding the degree of threat to individual species requires knowledge about their vulnerability to climate change, which is a function of intrinsic factors determined by species traits, as well as extrinsic factors determined by environmental conditions (Pacifici et al. 2015). Indeed, climate-change vulnerability has been defined as a combination of climate exposure, sensitivity, and adaptive capacity (Dawson et al. 2011). Climate exposure is typically considered in terms of the magnitude of change in longterm climate and climate variability experienced by a species (Beever et al. 2016, Foden and Young 2016). Sensitivity refers to the degree a species is affected by climate variability, and is a function of species' traits, including thermal tolerance, degree of ecological specialization, phenology, and vital rates (Foden and Young 2016). Adaptive capacity describes the ability of a species to adjust to climate change, and includes dispersal capacity, evolutionary capacity (genetic variability), and behavioral modifications (phenotypic plasticity; Dawson et al. 2011, Beever et al. 2016). The species that are most vulnerable to climate change are those that are exposed to large changes in climatically suitable habitat, have high sensitivity to climate change, and have low adaptive capacity (Beever et al. 2016, Foden and Young 2016). Boreal species occupy a diversity of niches, and exhibit a variety of life history characteristics, resulting in a range of exposure, sensitivity and adaptive capacity levels. Nevertheless, we provide some generalizations herein.

\section{Climate exposure}

Given the high expected rates of temperature increase in the north, boreal breeding species are likely to be among the most exposed to future changes in climate in a North American context (Rodenhouse et al. 2008). In particular, winter residents, which comprise $\sim 20 \%$ of all boreal bird species (Erskine 1977), may experience the largest direct changes in climate (Rodenhouse et al. 2009), while many Neotropical migrant species, i.e., longdistance migrants, may be less climate-exposed because of their reduced dependence on ecosystems influenced by northern climates. It should be noted, however, that resident species are already adapted to a much broader range of annual temperatures and weather conditions than migrant species, for which small temperature increases may be more meaningful. Furthermore, climate exposure of migratory species is compounded by an additional set of changes on their wintering grounds and along migration routes (Small-Lorenz et al. 2013).

The level of an individual species' climate exposure will also depend strongly on its climatic niche. Despite relatively large and intact current ranges, forest-associated species are more threatened by loss of habitat corresponding to their climatic niches than are grassland or woodland-associated birds (Langham et al. 2015, Stralberg et al. 2018a). Furthermore, for boreal-breeding species, changes in breeding niches are projected to be more substantial on average than changes in wintering niches (Naujokaitis-Lewis 2014, Langham et al. 2015). Some species with the largest projected loss of climatic niche space include boreal forest specialists like Black-backed Woodpecker (Picoides arcticus; Tremblay et al. 2018), Gray-cheeked Thrush (Catharus minimus; Stralberg et al. 2015a), Bicknell's Thrush (Catharus bicknelli; Rodenhouse et al. 2008, Cadieux et al. 2019), Rusty Blackbird (Euphagus carolinus; Stralberg et al. 2015a), Blackpoll Warbler (Setophaga striata; Ralston and Kirchman 2013), and Palm Warbler (Setophaga palmarum; Langham et al. 2015, 
Stralberg et al. 2015a). In comparison, many boreal species that nest in deciduous stands also have ranges that extend south into eastern deciduous forests. These species may experience gains in habitat suitability in some portions of their current range, especially in parts of the eastern boreal region that could experience increased productivity (D'Orangeville et al. 2016, Boulanger et al. 2017) and an increase in temperate tree species (Fisichelli et al. 2014). However, in the western boreal plains, habitat suitability for deciduous forest-associated species will likely decline, assuming that drought conditions and disturbance eventually lead to projected grassland conversion and forest loss (Stralberg et al. 2018b). Thus, niche loss and by extension climate exposure will likely vary by region.

\section{Climate sensitivity}

Most boreal species are estimated to have large, relatively stable populations because of their large, intact breeding ranges (Rosenberg et al. 2016). In addition, boreal birds exhibit a relatively low level of niche partitioning and habitat specialization (Mahon et al. 2016), perhaps due in part to the highly dynamic nature of the boreal forest biome (Schmiegelow and Mönkkönen 2002). These factors may generally result in low climate sensitivity of boreal bird species. However, species associated with late seralstage forests are likely more sensitive than early-seral associates because of lag times associated with vegetation growth and stand development (Stralberg et al. 2015b). For example, impacts of climate change are likely to be detrimental for Black-backed Woodpecker, an indicator species for deadwood and old-growth biodiversity in eastern boreal forests (Tremblay et al. 2009, 2010). Indeed, simulations of landscape change suggest up to a $92 \%$ decline in potential productivity for this species under all climatechange scenarios considered, primarily based on increased levels of natural and anthropogenic disturbance in the future (Tremblay et al. 2018).

In addition, species with declining populations have reduced ability to shift their distributions in response to climate change, as well as higher rates of extirpation along the trailing edges of their distributions (Ralston et al. 2017). Some boreal bird species may already be declining because of deteriorating habitat conditions on wintering grounds and along migratory routes, reductions in insect prey, or direct habitat loss. For example, Olivesided Flycatcher (Contopus cooperi) declined by $2.6 \%$ per year (range $1.91 \%$ to $3.34 \%$ ) between 1970 and 2015 , and by $\sim 79 \%$ from 1968 to 2006 (Environment and Climate Change Canada 2017), despite high availability of its suitable breeding habitat: forest edges and openings, especially recent burns. The high rate of decline combined with low breeding densities suggest a high sensitivity to climate change, especially to extreme weather events that may result in widespread nest failure or mortality (Anctil et al. 2017). Species with small population sizes are particularly sensitive to extreme weather events and other short-term fluctuations from which it may be difficult to recover (Sæther et al. 2016). For example, Bicknell's Thrush is among the few rangerestricted boreal species in North America (see Text Box 1). The high variability in this species' reproductive success (Townsend et al. 2015) and its small population size suggest high sensitivity to change. Furthermore, given the high proportion of migratory species in the boreal region, most boreal-breeding species will face additional pressures from threats occurring over the nonbreeding portions of the annual cycle including changes on wintering grounds and during migration (Lemoine et al. 2007).

For waterfowl, the abundant bogs and fens of the boreal region provide important breeding grounds, especially during years of drought in the North American prairies (Johnson and Grier 1988, Bethke and Nudds 1993). With some exceptions, most boreal waterfowl species have stable long-term trends, although species that breed late in the season are considered more sensitive to climate change, consistent with the hypothesis that increased temperatures may result in trophic mismatches between breeding ducks and their insect prey (Drever et al. 2012). Many shorebirds species that nest in the boreal region are showing population declines, however, and those species that migrate the longest distances are thought to be most sensitive (Thomas et al. 2006).

\section{Box 1. Bicknell's Thrush}

Bicknell's Thrush is listed as Threatened in Canada (Environment and Climate Change Canada 2016) and vulnerable globally (BirdLife International 2018). The species inhabits dense ( $\geq$ $15,000 \mathrm{stems} / \mathrm{ha}$ ) balsam fir forest stands at high elevations in the northeastern United States and eastern Canada (Connolly et al. 2002, Aubry et al. 2011, 2016, Townsend et al. 2015). Both habitat loss and the indirect effects of climate change, whereby increased temperatures are reducing available habitat via shifts in the balsam fir/spruce-mountain forest ecotone, are identified as threats to this species (COSEWIC 2009). Bicknell's Thrush has a highly restricted breeding range, and bioclimatic models project a loss of $>50 \%$ of its northeastern U.S. habitat over the next 30 years (Rodenhouse et al. 2008). In eastern Canada, forest landscape simulations also suggest dramatic declines in low-elevation habitat for Bicknell's Thrush by 2100, while higher elevation (> $900 \mathrm{~m}$ ) areas would likely act as climate refugia for the species (Cadieux et al. 2019). Thus, among boreal bird species, the Bicknell's Thrush is one of the most vulnerable to climate change, as it demonstrates (1) high long-term climate exposure based on the projected decline of its habitat, (2) short-term demographic sensitivity based on its low population size and variability in its reproductive success (Townsend et al. 2015), and (3) low adaptive capacity as a result of its long-distance migration strategy.

\section{Adaptive capacity}

Adaptive capacity is characterized by dispersal ability, genetic diversity (leading to directional selection), or phenotypic plasticity (leading to behavioral change). For example, some winter resident species, including irruptive species such as Pine Siskin (Spinus pinus), may have high capacity to respond to changing climate because of their ability to track fluctuating resources, such as climate-driven seed masting events (Strong et al. 2015). Conversely, long-distance migrant species may be less flexible (Small-Lorenz et al. 2013). As warmer climates cause earlier insect emergence and plant green-up, there is concern about mismatches in the timing of migratory bird arrival, compared with prey availability (Both and Visser 2001). Research from Europe suggests long-distance migrants have particularly 
inflexible("hard-wired") migration schedules, compared to shortdistance migrants (Both et al. 2009), and that phenological mismatches between migratory birds and insect prey can lead to population declines (Both et al. 2006). The high proportion of Neotropical migrant species in the boreal region suggests overall low adaptive capacity with respect to arrival times, resulting in greater potential disjuncts under shifting climate conditions (Both et al. 2009), especially where flexibility of migratory patterns is low (Gilroy et al. 2016). Thus far, however, mismatches between the timing of green-up and bird arrival have been documented for temperate North American species, but not boreal species (Mayor et al. 2017). Boreal species could be less sensitive than temperate birds to such mismatches if food availability is not limiting throughout the breeding season.

Although phenology and migration flexibility have received most research attention, the integration and characterization of adaptive capacity, particularly in relation to the role of genetic variability (Bay et al. 2018) and phenotypic plasticity, remains an emerging and active area of research (Beever et al. 2016, Wade et al. 2017).

\section{Assessing vulnerability}

According to the Partners in Flight (PIF) Watch List, only six of 86 species that are identified as species of conservation concern rely primarily on boreal habitats for breeding (Rosenberg et al. 2016). Climate change is identified as a major threat to persistence for only three of these species: Bicknell's Thrush (see Text Box 1), Rusty Blackbird, and Olive-sided Flycatcher. However, the combination of high future climate-change exposure in the north, loss of climates suitable for coniferous forests, and low adaptive capacity of long-distance migrants, means that boreal birds may become more vulnerable to extinction in the future.

There are multiple approaches and established frameworks for performing climate change vulnerability assessments (CCVA; Pacifici et al. 2015). Many of these involve assessing multiple species traits (e.g., Bagne et al. 2011, Young et al. 2016, Gardali et al. 2012). Some involve other indicators of climate sensitivity and adaptive capacity, such as population size and trend estimates (Gregory et al. 2009, U.S. Environmental Protection Agency 2009), while others use projections based on global climate models to estimate climate exposure (Gardali et al. 2012, Case and Lawler 2016, Aubin et al. 2018). Although a comprehensive analysis is outside the scope of this review, we present a first-order approximation of vulnerability of boreal forest birds for illustrative purposes. For a set of 54 forest-associated passerine species, we plotted long-term trend estimates (Environment and Climate Change Canada 2017), as a proxy for climate sensitivity (Ralston et al. 2017), against projections of midcentury climatic suitability according to Stralberg et al. (2015a) as a proxy for climate exposure (Fig. 2, Appendix 2). For Bicknell's Thrush, not covered by Stralberg et al. (2015a), we used an unpublished projection for Canada from Cadieux and Tremblay based on a model developed from U.S. data by Lambert and McFarland (2004). Migratory status was overlaid as an indicator of adaptive capacity. According to this classification, the PIF-identified climate-vulnerable species also fall into the high vulnerability category, as do species like Blackpoll Warbler and Gray-cheeked Thrush. Common Redpoll (Acanthis flammea) and Pine Grosbeak (Pinicola enucleator) may be considered to have high climate exposure and sensitivity, but also high adaptive capacity due to their resident status and nomadic habits. Other declining species such as Evening Grosbeak (Coccothraustes vespertinus) and Canada Warbler (Cardellina canadensis) have relatively low climate exposure, and may therefore be considered less climatevulnerable; whereas other species with high climate exposure, such as Palm Warbler, may not be particularly climate-sensitive, at least according to recent trends. We acknowledge that Breeding Bird Survey trends are biased toward the southern boreal region and may not adequately represent trends in northern populations (Van Wilgenburg et al. 2018). Thus, we caution against overinterpretation and suggest that a more rigorous, in-depth CCVA be performed to adequately characterize vulnerability and situate risks.

Fig. 2. Components of climate-change vulnerability plotted for 54 boreal-breeding passerine species (see Appendix 2 for species names and data values). Long-term trend values are based on Canada-wide BBS trend estimates (Environment and Climate Change Canada 2017), converted to proportional change and log-transformed. For all species but Bicknell's Thrush (BITH; Catharus bicknelli), projected future change values are based on midcentury (2041-2070) climate-based mean density estimates for the North American boreal region (Stralberg et al. 2015a), converted to proportional change and log-transformed. For $\mathrm{BITH}$, the future projection is from Cadieux and Tremblay (unpublished) based on a model from Lambert and McFarland (2004). Symbols for each species are colored according to migratory status: black $=$ long-distance migrant; gray $=$ shortdistance migrant; and white $=$ resident or nomadic.

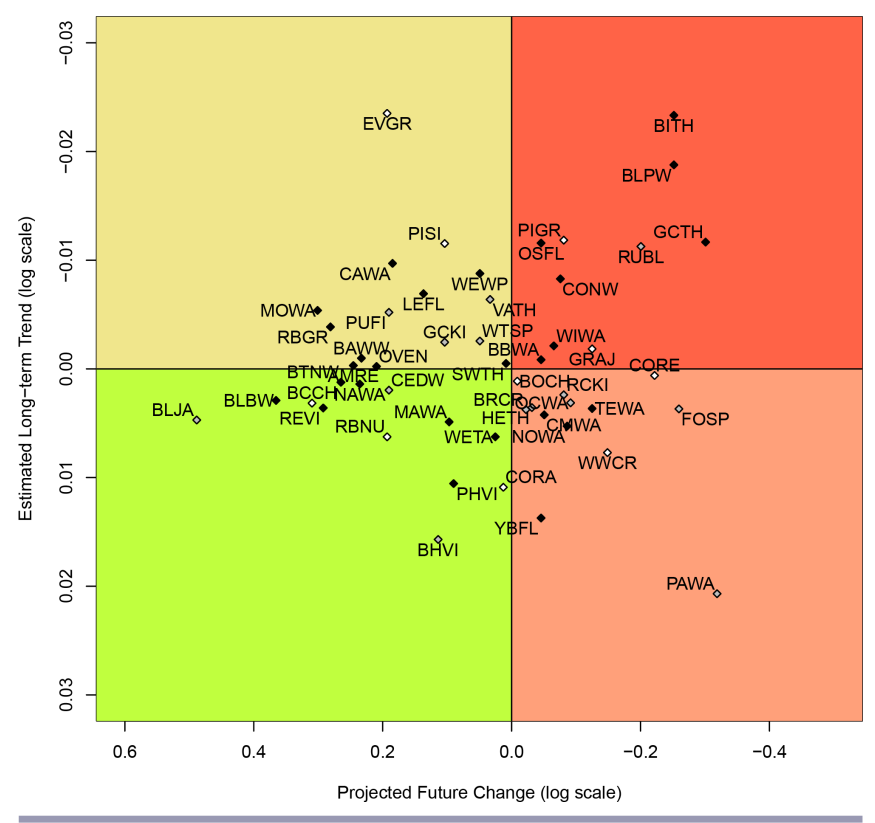

\section{CONSERVATION STRATEGIES}

In an era of rapid environmental change, it is paramount to consider future potential changes alongside current environmental conditions to conserve and manage populations (Araújo et al. 2004, Veloz et al. 2013). However, selecting effective conservation 
strategies is a nontrivial task that can vary by species and ecosystems and the associated climate change risks, amongst other factors. We present a conceptual framework for advancing effective conservation strategies for boreal birds in a changing climate based on species' vulnerability, adapted from the landscape-based framework proposed by Gillson et al. (2013). Importantly, we extend vulnerability assessments into the conservation decision space and link vulnerability rankings to four corresponding conservation strategies: in situ habitat management, habitat manipulation and translocation, targeted protection of climate refugia and stepping stones, and conservation of diverse and connected landscapes (Fig. 3). Species' climate change vulnerability can be plotted along the axes of long-term climate exposure, sensitivity, and adaptive capacity. For simplicity, we combined the axes of sensitivity and adaptive capacity, given that adaptive capacity is not easily estimated at the species level. This combined axis is termed short-term demographic sensitivity, and refers to intrinsic factors determined by species traits, as opposed to extrinsic factors determined by environmental change. Species location along the two axes in this framework suggests the nested suite of conservation strategies best suited to their circumstances. We elaborate each of the conservation strategies, and then consider the potential for integration via systematic conservation planning.

Fig. 3. Vulnerability-adaptation framework, adapted from Gillson et al. (2013), depicting appropriate conservation actions suggested by individual species' short-term demographic sensitivity and long-term climate exposure. Short-term demographic sensitivity combines climate sensitivity and adaptive capacity, and high values indicate species with population dynamics strongly affected by climate or under strong risk of extinction. Climate exposure refers to the extent to which species rely on habitats or regions expected to undergo significant changes under warming climate. This figure should be interpreted similarly to a Punnett square, where species are assigned a value along these two axes, which then determines the conservation strategies best suited to their circumstances.

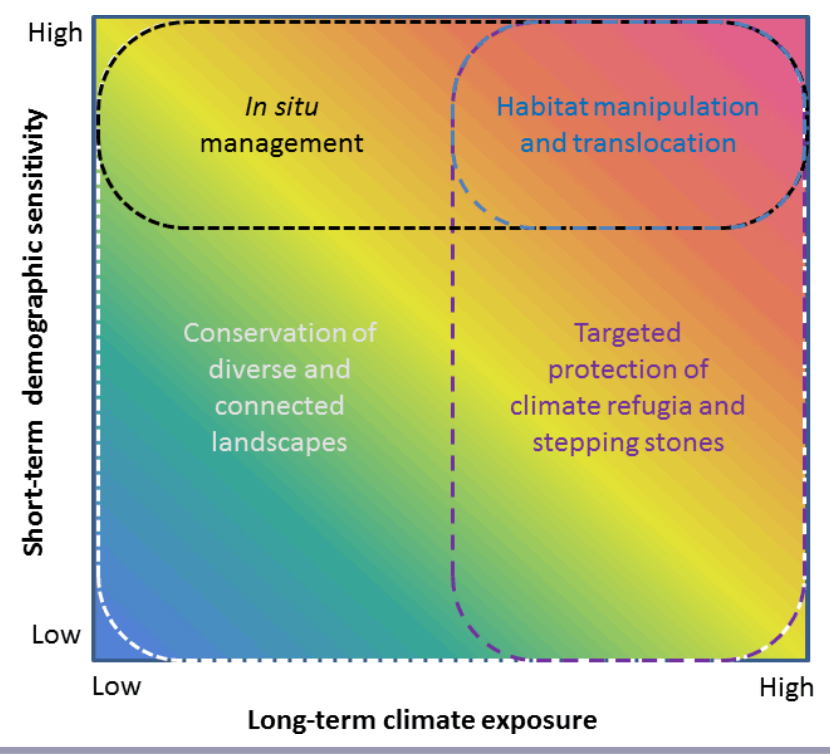

\section{In situ management}

For demographically sensitive species with declining populations, adaptation to climate change depends on management of current threats and species recovery in situ, to improve adaptive capacity and facilitate future shifts in distribution (Fig. 3, upper portion). Species that are highly climate-sensitive or currently at risk of extinction, but that have projected increases in future habitat suitability (low climate exposure), may eventually benefit from climate change once populations are stabilized, suggesting that major up-front conservation investments can prevent the need for future action. Given that species with declining populations often experience contracting range margins (Lawton 1993, Lenoir and Svenning 2015), sometimes in conjunction with decreasing local densities, potential distributional increases in response to climate change may not occur until current populations are stable or increasing. Consequently, investments in future suitable habitat may be premature or at least lower priority for these species. Instead, it will first be necessary to invest in measures aimed at increasing local populations and preventing further declines via critical habitat protection. For example, climate change may eventually benefit Canada Warbler, a species listed as Threatened under Canada's Species at Risk Act (SARA), given projected increases in deciduous vs. coniferous tree species. However, individuals of this species tend to be clustered spatially and local populations are often relatively isolated, which may be exacerbated by industrial development (Grinde and Niemi 2016, Hunt et al. 2017). Thus, increasing current habitat availability and connectivity will be more important than protecting areas of projected future occupancy for Canada Warbler and other similar species.

\section{Habitat manipulation and translocation}

Species that are demographically sensitive and declining, and also subject to high climate exposure, may warrant more extreme intervention, such as habitat manipulation or even translocation (Griffith et al. 1989; Fig. 3, right). In the near term, large-scale reforestation conducted postharvest or postfire, especially based on climatically suitable genotypes (Millar et al. 2007, Gray and Hamann 2011), can help encourage the growth of tree species that might otherwise not have suitable conditions for establishment because of drought conditions (Gauthier et al. 2014). However, when the magnitude of change is great enough that species can no longer persist in their existing landscapes, species management must be viewed from a much broader scale perspective, and managed translocation (also known as assisted migration or assisted colonization) of individuals into newly suitable habitats outside of their current range may be considered (McLachlan et al. 2007, Hoegh-Guldberg et al. 2008). In managed forests, this effort may involve translocation of tree species or genotypes in conjunction with forestry operations (Gray et al. 2011, Williams and Dumroese 2013). Although translocation of birds has previously only been conducted in conjunction with captive breeding and for critically endangered species with very small populations (Griffith et al. 1989), more proactive programs could be established with wild populations. Given the potential for unintended consequences such as community disruption and disease spread (Ricciardi and Simberloff 2009), translocation should be approached with caution and considered for movements within, rather than between, biogeographic regions (Hoegh-Guldberg et al. 2008). For example, the current break in 
boreal forest habitat across the northwestern cordillera mountain ranges spanning Alaska and the Yukon could be bridged via translocation. Although climate projections suggest increased future connectivity across the cordillera (Stralberg et al. 2017), and some species have recently appeared on the Alaska side (Gibson and Withrow 2015), translocation could speed up the process, also facilitating future upslope migration.

\section{Targeted protection of climate refugia and stepping stones}

For boreal bird species with high climate exposure, but no present indication of population decline, conservation investments may be most efficiently directed toward identification and protection of climate refugia, areas of relative stability for one or more species under climate change (Ashcroft 2010, Keppel et al. 2012, Michalak et al. 2018), and stepping stones (Fig. 3, right-hand portion). More specifically, refugia may be defined as "areas relatively buffered from contemporary climate change over time that enable persistence of valued physical, ecological, and sociocultural resources" (Morelli et al. 2016). Whether they persist indefinitely or represent short-term "hold-outs" (Hannah et al. 2014), refugia represent areas of high conservation value in a changing climate, and may support higher levels of endemism over the long term (Sandel et al. 2011). In the boreal region, given rapid rates of change over large areas, this effort will involve identifying macro-scale climate refugia, largely driven by proximity to cooler and wetter high elevation and coastal influences (Stralberg et al. 2015b).

Using a climate velocity-based approach to mapping individual species refugia (Stralberg et al. 2018a), areas of highest end-ofcentury refugia potential for forest-associated boreal birds were found primarily in western mountainous portions of Alaska, British Columbia, and the Yukon, and along the Québec and Labrador coasts in the east (Fig. 4, Appendix 3). Depending on species' weightings, portions of Ontario and interior Québec also had high refugia potential. Generally speaking, these refugia can be characterized as areas of relatively moderate climates, e.g., marine and lacustrine coastal areas, and mountain areas projected to remain cool and wet in a rapidly warming climate. Individual species refugia were also found along the latitudinal and elevational ecotones that currently represent species' northern range limits, e.g., the boreal-taiga transition zone. Importantly, however, refugia are not static and will contract over time in a period of rapid change. Thus, conservation efforts will need to consider multiple time periods and the resulting "temporal corridors" (Rose and Burton 2009) or "stepping stones" (Hannah et al. 2014) needed to bolster species' existing populations and facilitate gradual distribution shifts. For example, a conservation prioritization exercise focused on boreal passerine refugia found significant overlap among solutions for different time periods, but also suggested that to conserve an area representing $10 \%$ of combined boreal species' habitat throughout the 21 st century, three times as much land would be needed compared to presentday conditions (Stralberg et al. 2015b). Efficiencies are gained by conserving more land; e.g., 30\% of combined habitat value can be obtained with only twice the land area of present-day conditions.
Fig. 4. Multispecies end-of-century refugia index for 53 boreal forest-associated species. Using an approach based on locating nearest climatic analogs (Stralberg et al. 2018a), we calculated individual species refugia indices $(0=$ low, $1=$ high $)$ based on end-of-century climate projections (Stralberg et al. 2015a) and averaged them to obtain a multispecies index of refugia value. Areas of highest combined future refugia potential (dark blue) include western mountain regions and eastern coastal regions with a maritime influence. These areas represent the most efficient options for protecting current boreal forest species and communities. See Appendix 3 for detailed methods and midcentury results.

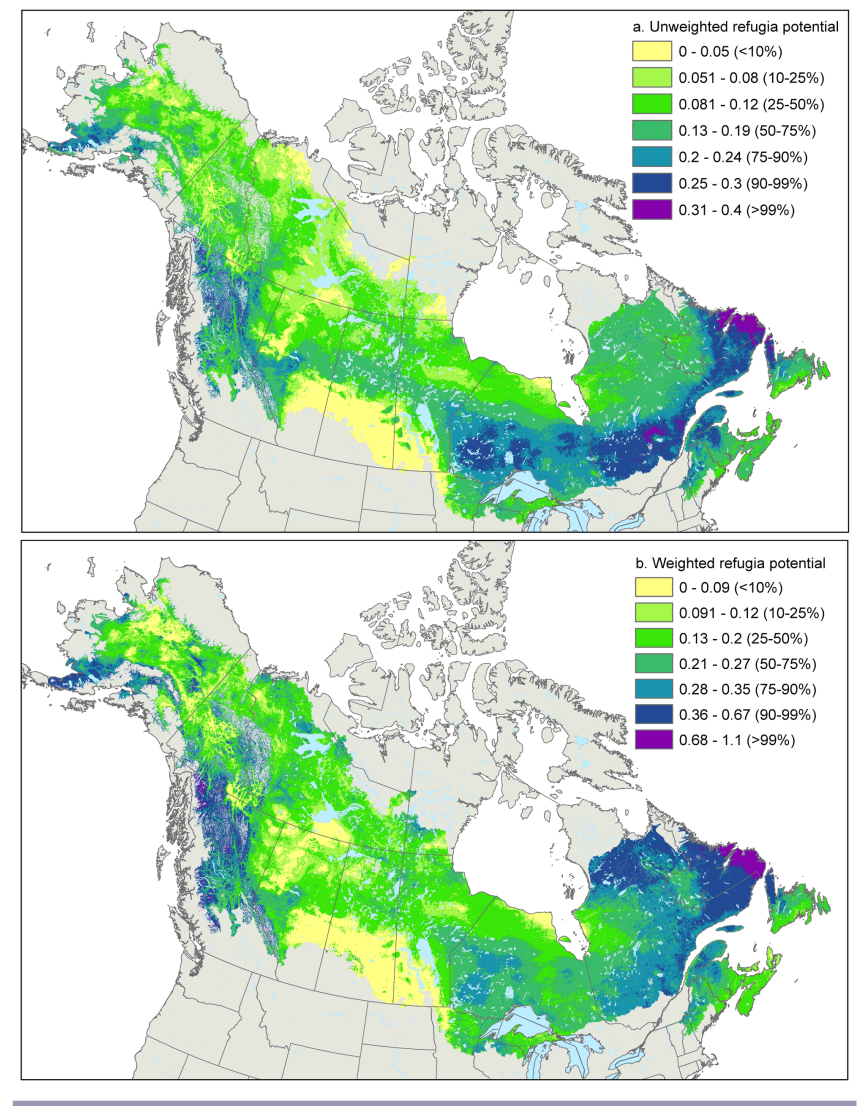

Climatic microrefugia, driven by local terrain effects such as aspect and cold air drainage, have also been advocated as important conservation priorities in regions of rugged terrain and steep climatic gradients (Ashcroft 2010, Dobrowski 2011). The generally flat terrain and corresponding climate gradients may mean limited opportunity exists for climatic microrefugia over much, but not all of the boreal region. However, other types of refugia, i.e., wetlands and riparian zones (Selwood et al. 2015, McLaughlin et al. 2017), and various types of fire refugia (Krawchuk et al. 2016, Nielsen et al. 2016), may play an important role yet to be fully understood in boreal regions. For example, moisture-conserving peatland systems may be able to persist longer than surrounding upland forests (Waddington et al. 2015, Schneider et al. 2016, Thompson et al. 2017), serving as climate refugia for some species. 


\section{Conservation of diverse and connected landscapes}

In general, land-based approaches such as "conserving nature's stage" (Beier and Brost 2010) by promoting geophysical diversity (Anderson and Ferree 2010), maintaining natural disturbance dynamics (Noss 2001, Leroux et al. 2007), and maintaining habitat connectivity to facilitate broad-scale distributional shifts, e.g. along gradients (Halpin 1997, Noss 2001, Hodgson et al. 2009), may prove most effective in maintaining biodiversity without requiring certainty about specific long-term changes in climate (Fig. 3, entire square). Given the magnitude of change expected and the number of species affected by climate change, individual species management will become increasingly inefficient for conservation of bird diversity. In the large and relatively intact boreal region, some researchers simply call for large-scale protection to maintain natural disturbance processes and wide-ranging species (Badiou et al. 2013). More targeted approaches aim to optimize the selection of large, representative, and intact benchmarks for conservation, in conjunction with broad-scale adaptive management of remaining areas (Leroux et al. 2007, Schmiegelow et al. 2014). In a climate-change context, several species-neutral approaches have been suggested that deemphasize the "actors" (species) and focus instead on the "stage" (environmental setting) that maintains diversity. Species-neutral strategies proposed for efficient use of conservation resources in a changing climate include the identification of (1) representative "land facets" or "enduring features" composed of different combinations of geomorphological features to preserve diversity in different forms (Anderson and Ferree 2010, Beier and Brost 2010, Theobald et al. 2015, Magness et al. 2018); (2) areas of low climate velocity and high diversity of microclimates to indicate high macro- and microrefugia potential (Ackerly et al. 2010, Lawler et al. 2015, Carroll et al. 2017); and (3) climate corridors (Carroll et al. 2018) and environmental gradients (Noss 2001) to facilitate distribution shifts.

\section{Climate-smart systematic conservation planning}

Although these conservation strategies may be applied on an individual species basis (or independent of species, in the case of species-neutral approaches), multispecies planning processes are likely more efficient. Systematic conservation planning (SCP) involves finding efficient solutions to representative reserve design according to explicit conservation objectives and constraints (Margules and Pressey 2000). In a rapidly changing world with increasing constraints, spatially explicit systematic conservation planning tools such as Zonation (Moilanen 2007) and Marxan (Ball et al. 2009) will be increasingly useful for navigating complex conservation objectives. Beyond the identification of recommended protected areas per se, SCP algorithms and tools are useful for identifying geographic areas of high diversity, abundance, and complementarity among species. These tools can be adapted to consider projected future species distributions and discount for future (and current) uncertainty (Carroll et al. 2010, Kujala et al. 2013, Loyola et al. 2013, Watson et al. 2013). Indeed, they have already been applied to boreal forest vegetation (Powers et al. 2017) and passerine birds (Stralberg et al. 2015b, 2018c) at a continental scale.
Boreal bird-focused Zonation analyses for the Canadian boreal region (Stralberg et al. 2018c) highlighted the large contrasts between conservation priorities based on current versus future projected distributions of birds. However, by considering both current and future (midcentury) projected distributions, conservation priorities changed more subtly, with key northern regions of increased importance under climate change easily identified by difference maps. In that exercise, discounting areas with high landscape disturbance and prediction uncertainty, as well as weighting species according to their population status, helped to constrain solutions and identify areas with consistently high conservation value under multiple different sets of assumptions. Nevertheless, results varied greatly not just according to the time periods considered, but also with respect to conservation objective (diversity or representation) and geographic focus (regional or boreal-wide). This variation reflects in part the broad, dispersed ranges of boreal passerines and lack of clear diversity hotspots for these species; but it also emphasizes the importance of a priori articulation of conservation objectives and constraints (Stralberg et al. 2018c).

Indeed, the central challenge with SCP is to identify conservation objectives in a world filled with trade-offs and value judgments, including whether to weight some species and ecosystems higher than others, and whether to focus on long-term refugia or areas of imminent threat. Conservation triage entails selecting species (McIntyre et al. 1992) or populations (McDonald-Madden et al. 2008) to be conserved based on their probability of survival given a certain level of investment. Meeting this objective may mean sacrificing some highly vulnerable species with low probability of survival. Fundamentally, however, triage simply implies a prioritization of actions to maximize conservation benefit (Bottrill et al. 2008).

Our vulnerability-conservation strategy framework for boreal birds can also be used to guide inputs to multispecies conservation planning exercises, and is not intended as a prescriptive one-sizefits-all approach. For example, the relative weighting of species' current vs. future distributions may be informed by species' sensitivity and estimated population trends. In addition, maintenance of climate refugia and protection and conservation of stepping stones may constitute appropriate planning objectives for species with high climate exposure. Nevertheless, given the inherent trade-offs among species, "climate-smart" conservation planning will need to involve a combination of objectives and strategies to accommodate change while efficiently conserving as many species and communities as possible (Hansen et al. 2010, Groves et al. 2012).

\section{CHALLENGES AND APPROACHES TO CONSERVATION OF BOREAL BIRDS IN A CHANGING CLIMATE}

In addition to the universal conservation challenges associated with climate change, such as scale and uncertainty (e.g., Root and Schneider 2006, Heller and Zavaleta 2009), we identify three main challenges to conservation of boreal birds in particular: (1) lack of baseline information to detect and attribute past and ongoing changes in boreal bird populations; (2) uncertainties as to the near-term ecological consequences of climate change, especially at the forest stand level; and (3) complexities associated with the 
large spatial scales at which changes in boreal bird communities will occur, as well as migratory life cycles that span much of the western hemisphere. We detail these three challenges and indicate some of the approaches, including organizational structures and tools, available to address them.

\section{Data gaps in a changing climate call for proactive investments in monitoring}

Boreal bird conservation is challenged by a lack of data and resources, especially with respect to migratory species for which knowledge of wintering ground conditions and associated vulnerabilities is scarce. Trend data are often biased and incomplete, and specific habitat requirements and distributional limits are still under study. Boreal bird population trends are uncertain, and reliability is classified as poor for $60 \%$ of species (Blancher et al. 2009), with available data not representative of boreal forest geography (Machtans et al. 2014, Desrochers and Drolet 2017) or disturbance levels (Van Wilgenburg et al. 2015). Indeed, the majority of Breeding Bird Survey data come from the southern portion of the biome and sampling efforts are inconsistent across the boreal forest region (Niemi et al. 1998, Schmiegelow and Mönkkönen 2002, Blancher et al. 2009, Machtans et al. 2014). Across all four boreal bird conservation regions (BCRs) in Canada, improving monitoring and filling knowledge gaps are key components of landbird conservation strategies (Environment and Climate Change Canada 2013). As well, the definition and identification of critical habitat for boreal species listed as at-risk under SARA is challenging because of incomplete knowledge of their large breeding range limits, variations in habitat requirements across those large ranges, and the likely role of wintering ground conditions in population declines (Wilson et al. 2018).

These data challenges will be exacerbated by climate change, which is occurring without adequate understanding of historic and current northern distributional limits, population sizes, and population-limiting factors. Detection and attribution of change is particularly challenging without extensive baseline knowledge and sampling effort. For example, some steeply declining species like Blackpoll Warbler and Rusty Blackbird are also among the most data poor. These particular species are projected to experience large contractions in the climatic suitability of their northern forested habitats, and are thus among the most vulnerable from a bioclimatic niche standpoint (Stralberg et al. 2015a). Historical declines for Rusty Blackbird coincide with climatic warming and multidecadal climate cycles (McClure et al. 2012), and also with loss and degradation of wintering ground habitat and historical blackbird control programs (Greenberg and Matsuoka 2010). Accordingly, disentangling causes of decline, especially for migratory species, will remain a formidable obstacle in the allocation of scarce conservation resources. A proactive investment in the monitoring of northern species and analysis of historical changes in abundance and distribution will be key to improving conservation outcomes under climate change. Within our framework (Fig. 3), improved information on population trend and status can refine the position of each species within the spectrum of short-term demographic sensitivity, thereby facilitating the decisions about whether species conservation should focus on landscape-level strategies or intensive approaches such as translocation and in situ management.

\section{Uncertainties about future change scenarios can be evaluated with landscape simulation tools}

Although detection and causal attribution of historical change are challenging, projections of future boreal climatic niches are fairly consistent, with the climate-change "signal" greater than the model "noise" for most passerine species (Stralberg et al. 2015a). Greater uncertainty lies with the rate of change in the boreal region, given the potential for lags in vegetation and other ecosystem responses to climate change, and with species' ability to keep pace or adapt to changing climates, especially given other anthropogenic disturbances and climate-induced changes in natural disturbance regimes (Boulanger et al. 2017). Vegetation is a key habitat component for boreal birds, but plant species may respond slowly to new conditions as local climates improve or deteriorate. Consequently, although boreal birds are highly vagile and can theoretically track shifting climatic niches, many species will be held back because of delayed response of habitat components to climate change (Vissault 2016). Others may face new competition or predation pressures as southern-associated species advance northward. Such differential species' responses to climate change are likely to result in altered biotic interactions, leading to unanticipated trajectories of community change (Blois et al. 2013). Boreal bird communities may thus build considerable immigration credit and extinction debt locally, because of time lags in species colonization and extinction (Jackson and Sax 2010). Transient surpluses and deficits in regional bird diversity have important ramifications for conservation. For example, protecting an area where both the current vegetation and local climate are suitable may benefit that species in the near term, but only until the new climate makes the area unsuitable. Particularly uncertain is how long wetland habitats can persist in a state of disequilibrium, given the negative feedbacks that maintain moisture in these systems, especially in larger peatland complexes (Waddington et al. 2015). Differential rates of change in upland and lowland habitats may result in novel landscapes and hydrologic systems, posing challenges for species and managers (Schneider et al. 2016). Therefore, improved ecological forecasts are needed to fully describe the extent of long-term climate exposure for boreal birds, and thus allow us to evaluate for which species and in which regions targeted protection of climate refugia is possible, or whether we will need to rely on broader approaches based on conservation of biophysical diversity.

It is increasingly possible to simulate realistic scenarios of landscape change that can inform focused, short-term management questions at landscape and regional scales. Dynamic simulation models are needed to address short-term, i.e., decadal scale, vegetation trajectories. Landscape simulation frameworks such as LANDIS-II (Scheller and Mladenoff 2004, Scheller et al. 2007) and ALFRESCO (Rupp et al. 2000) include modules to simulate stand-, e.g., forest succession or growth, and landscapescale, e.g., natural and anthropogenic disturbances, processes at meaningful temporal and spatial scales, allowing for the characterization of wildlife habitats (Rupp et al. 2006) Furthermore, despite significant scale challenges (Cushman et al. 2007), landscape simulation models can be used to simulate the impact of climate change on various ecological processes (Scheller et al. 2007), and may be useful to predict the impacts of changing 
climate on bird habitats (Marcot et al. 2015, Tremblay et al. 2018, Cadieux et al. 2019). By incorporating spatial legacies of the landscape, future dynamics of forest disturbances, and trajectories of vegetation succession, landscape simulation models can provide more realistic projections of bird habitats than species distribution models alone (De Cáceres et al. 2013, Vissault 2016). Where data permit, species' demographic responses to climate and landscape change can be simulated with metapopulation dynamics models that incorporate species sensitivity and adaptive capacity through modeled vital rates (Keith et al. 2008, Naujokaitis-Lewis et al. 2013, Bonnot et al. 2018). Major developments are still needed to improve the spatial and temporal scope of these models, and address key uncertainties such as peatland and permafrost dynamics. Nonetheless, land-use planning processes will increasingly depend on such approaches to address the complexities of climate change.

\section{Large-scale changes and migratory life cycles require continent-wide collaboration}

Finally, given the large areas and high climate velocities found in the boreal region, changes in boreal bird communities will occur at large spatial extents that cross international and other jurisdictional boundaries (Naujokaitis-Lewis 2014, Stralberg et al. 2017). Southern portions of the eastern boreal region are likely to experience colonization by eastern deciduous forest-associated birds (Berteaux et al. 2010), while grassland-associated species will expand into southern parts of the western boreal region (Nixon et al. 2016), raising the issue of what should be considered invasive vs. natural (Boulanger et al. 2016). In the north, discontinuities between the United States (Alaska) and Canada in suitable habitat for a number of boreal species are projected to disappear under future climates, opening up new range expansion corridors through the Yukon and Alaska, with high potential for novel species communities to form (Stralberg et al. 2017). Furthermore, because of the migratory habits of most boreal species, breeding population abundances are linked to conditions on wintering grounds and along migration routes (Marra et al. 1998, Norris and Taylor 2005, Wilson et al. 2018). Annual life cycle analysis has been identified as a major deficit in avian research, and more studies of wintering ground effects and migratory connectivity between breeding and wintering grounds are needed (Faaborg et al. 2010, Marra et al. 2015).

Thus, in a changing climate, the combination of broad-scale range shifts and complex annual cycles will shift management responsibilities and generate new questions about where conservation efforts are most efficiently enacted. This situation increases the need for cross-jurisdictional and interagency collaboration in the management of migratory bird species, and suggests that international organizations such as Partners in Flight (PIF) and associated regional joint ventures will play an important role in the development of climate-smart conservation measures for boreal birds. The PIF Landbird Conservation Plan (Rosenberg et al. 2016) considers climate change and wintering ground factors in its vulnerability assessment, but more research and data are needed to adequately address climate-change threats. Also, given PIF's huge geographic and taxonomic scope, more focused and direct international partnerships, preferably based on migratory connectivity patterns, are needed to conserve migratory boreal birds in the face of climate change. Voluntary, collaborative partnerships such as the Northwest Boreal Landscape Conservation Cooperative in Alaska, British Columbia, and the Yukon and Northwest Territories (https:// nwblcc.org/) currently provide among the only opportunities to incorporate the broad-scale challenges of climate change into avian conservation planning in ways that cut across jurisdictional boundaries.

\section{CONCLUSION}

The boreal region of North America is expected to experience rapid and dramatic changes in climate over upcoming decades. Resulting ecological changes will lead to a pronounced shift in the conservation landscape. Because of its vast size and the predominance of land undisturbed by industrial activity, the boreal region is particularly well suited to accommodation of change via a large landscape conservation approach, especially in northern reaches. However, prioritization of limited conservation resources will be needed if development continues to increase the human footprint on the landscape. Furthermore, some species may need active intervention to persist in the face of rapid change, especially given additional pressures during nonbreeding portions of the annual cycle. Our vulnerability-adaptation framework accommodates differential vulnerability and provides guidance on strategies to pursue for different species, recognizing that multiple strategies are often needed. Of course it is impossible to prescribe comprehensive, long-term conservation actions for such a wide range of species, and detailed scrutiny of individual species' life histories, habitat associations, and population demographics will be needed to inform specific conservation measures. Although our proposed framework can guide conservation action based on species' individual needs, its implementation will require largescale, interagency coordination on recovery plans, as well as flexibility and forethought in the management of forests, the designation of critical habitat, and the establishment of protected areas.

Responses to this article can be read online at: http://www.ace-eco.org/issues/responses.php/1363

\section{Acknowledgments:}

We thank Nicole Barker, Marcel Darveau, and Steve Cumming for organizing the Conservation of Boreal Birds Symposium at the North American Congress for Conservation Biology meeting in Madison, Wisconsin in July 2016, and for soliciting this special feature paper. We also thank two anonymous reviewers, Steve Cumming, and Keith Hobson for helpful feedback on an earlier draft. This paper is a contribution of the Boreal Avian Modelling (BAM) Project, an international research collaboration on the ecology, management, and conservation of boreal birds. We acknowledge BAM's members, avian and biophysical data partners, and funding agencies (including Environment and Climate Change Canada), listed in full at http://www.borealbirds.calindex.php/ acknowledgements. D. Stralberg was also funded by the Wilburforce Foundation. Finally, we acknowledge the hundreds of skilled volunteers who contributed to the collection of Breeding Bird Survey data and other BAM data. 


\section{LITERATURE CITED}

Ackerly, D. D., S. R. Loarie, W. K. Cornwell, S. B. Weiss, H. Hamilton, R. Branciforte, and N. J. B. Kraft. 2010. The geography of climate change: implications for conservation biogeography. Diversity and Distributions 16:476-487. https://doi.org/10.1111/ j.1472-4642.2010.00654.x

Anctil, A., H. A. Johansen, and J. A. Tremblay. 2017. Écologie de nidification du moucherolle à côtés olive dans un paysage sous aménagement forestier de la forêt boréale de l'Est. Le Naturaliste canadien 141:53-60. http://dx.doi.org/10.7202/1039736ar

Anderson, M. G., and C. E. Ferree. 2010. Conserving the stage: climate change and the geophysical underpinnings of species diversity. PLOS ONE 5:e11554. https://doi.org/10.1371/journal. pone.0011554

Araújo, M. B., M. Cabeza, W. Thuiller, L. Hannah, and P. H. Williams. 2004. Would climate change drive species out of reserves? An assessment of existing reserve-selection methods. Global Change Biology 10:1618-1626. https://doi.org/10.1111/ j.1365-2486.2004.00828.x

Ashcroft, M. B. 2010. Identifying refugia from climate change. Journal of Biogeography 37:1407-1413. https://doi.org/10.1111/ j.1365-2699.2010.02300.x

Aubin, I., L. Boisvert-Marsh, H. Kebli, D. McKenney, J. Pedlar, K. Lawrence, E. H. Hogg, Y. Boulanger, S. Gauthier, and C. SteMarie. 2018. Tree vulnerability to climate change: improving exposure-based assessments using traits as indicators of sensitivity. Ecosphere 9:e2108. http://dx.doi.org/10.1002/ ecs 2.2108

Aubry, Y., A. Desrochers, and G. Seutin. 2011. Response of Bicknell's Thrush (Catharus bicknelli) to boreal silviculture and forest stand edges: a radio-tracking study. Canadian Journal of Zoology 89:474-482. http://dx.doi.org/10.1139/z11-011

Aubry, Y., A. Desrochers, and G. Seutin. 2016. Regional patterns of habitat use by a threatened forest bird, the Bicknell's Thrush (Catharus bicknelli), in Quebec. Canadian Journal of Zoology 94:301-309. http://dx.doi.org/10.1139/cjz-2015-0209

Badiou, P., R. Baldwin, M. Carlson, M. Darveau, P. Drapeau, K. Gaston, J. Jacobs, J. Kerr, S. Levin, M. Manseau, G. Orians, S. Pimm, H. Possingham, P. Raven, F. Reid, D. Roberts, T. Root, N. Roulet, J. Schaefer, D. Schindler, J. Strittholt, N. Turner, and J. Wells. 2013. Conserving the world's last great forest is possible: here's how. International Boreal Conservation Science Panel, Boreal Songbird Initiative, Seattle, Washington, USA. [online] URL: https://www.borealbirds.org/publications/conserving-worldslast-great-forest-possible-heres-how

Bagne, K. E., M. M. Friggens, and D. M. Finch. 2011. A system for assessing vulnerability of species ( $S A V S$ ) to climate change. General Technical Report RMRS-GTR-257. U.S. Forest Service, Rocky Mountain Research Station, Fort Collins, Colorado, USA. http://dx.doi.org/10.2737/RMRS-GTR-257

Ball, I. R., H. P. Possingham, and M. Watts. 2009. Marxan and relatives: software for spatial conservation prioritisation. Pages 185-195 in A. Moilanen, K. A. Wilson, and H. P. Possingham, editors. Spatial conservation prioritisation: quantitative methods and computational tools. Oxford University Press, Oxford, UK.
Baltzer, J. L., T. Veness, L. E. Chasmer, A. E. Sniderhan, and W. L. Quinton. 2014. Forests on thawing permafrost: fragmentation, edge effects, and net forest loss. Global Change Biology 20:824-834. http://dx.doi.org/10.1111/gcb.12349

Bay, R. A., R. J. Harrigan, V. L. Underwood, H. L. Gibbs, T. B. Smith, and K. Ruegg. 2018. Genomic signals of selection predict climate-driven population declines in a migratory bird. Science 359:83-86. http://dx.doi.org/10.1126/science.aan4380

Bayne, E., L. Leston, C. L. Mahon, P. Sólymos, C. Machtans, H. Lankau, J. R. Ball, S. L. Van Wilgenburg, S. G. Cumming, T. Fontaine, F. K. A. Schmiegelow, and S. J. Song. 2016. Boreal bird abundance estimates within different energy sector disturbances vary with point count radius. Condor 118:376-390. http://dx.doi. org/10.1650/CONDOR-15-126.1

Beever, E. A., J. O'Leary, C. Mengelt, J. M. West, S. Julius, N. Green, D. Magness, L. Petes, B. Stein, A. B. Nicotra, J. J. Hellmann, A. L. Robertson, M. D. Staudinger, A. A. Rosenberg, E. Babij, J. Brennan, G. W. Schuurman, and G. E. Hofmann. 2016. Improving conservation outcomes with a new paradigm for understanding species' fundamental and realized adaptive capacity. Conservation Letters 9:131-137. http://dx.doi.org/10.1111/ conl.12190

Beier, P., and B. Brost. 2010. Use of land facets to plan for climate change: conserving the arenas, not the actors. Conservation Biology 24:701-710. https://doi.org/10.1111/j.1523-1739.2009.01422. $\mathrm{x}$

Berteaux, D., S. de Blois, J.-F. Angers, J. Bonin, N. Casajus, M. Darveau, F. Fournier, M. M. Humphries, B. McGill, J. Larivée, T. Logan, P. Nantel, C. Périé, F. Poisson, D. Rodrigue, S. Rouleau, R. Siron, W. Thuiller, and L. Vescovi. 2010. The CC-Bio Project: studying the effects of climate change on Quebec biodiversity. Diversity 2:1181-1204. https://doi.org/10.3390/d2111181

Bethke, R. W., and T. D. Nudds. 1993. Variation in the diversity of ducks along a gradient of environmental variability. Oecologia 93:242-250. http://dx.doi.org/10.1007/BF00317677

BirdLife International. 2018. Catharus bicknelli. IUCN Global Species Programme Red List Unit, Cambridge, UK. [online] URL: http://dx.doi.org/10.2305/IUCN.UK.2018-2.RLTS. T22728467A132032920.en

Blancher, P. J., R. D. Phoenix, D. S. Badzinski, M. D. Cadman, T. L. Crewe, C. M. Downes, D. Fillman, C. M. Francis, J. Hughes, D. J. T. Hussell, D. Lepage, J. D. McCracken, D. K. McNicol, B. A. Pond, R. K. Ross, R. Russell, L. A. Venier, and R. C. Weeber. 2009. Population trend status of Ontario's forest birds. Forestry Chronicle 85:184-201. http://dx.doi.org/10.5558/tfc85184-2

Blois, J. L., P. L. Zarnetske, M. C. Fitzpatrick, and S. Finnegan. 2013. Climate change and the past, present, and future of biotic interactions. Science 341:499-504. http://dx.doi.org/10.1126/ science. 1237184

Bonnot, T. W., W. A. Cox, F. R. Thompson, and J. J. Millspaugh. 2018. Threat of climate change on a songbird population through its impacts on breeding. Nature Climate Change 8:718-722. http:// dx.doi.org/10.1038/s41558-018-0232-8

Both, C., S. Bouwhuis, C. M. Lessells, and M. E. Visser. 2006. Climate change and population declines in a long-distance 
migratory bird. Nature 441:81-83. http://dx.doi.org/10.1038/ nature04539

Both, C., C. A. M. Van Turnhout, R. G. Bijlsma, H. Siepel, A. J. Van Strien, and R. P. B. Foppen. 2009. Avian population consequences of climate change are most severe for long-distance migrants in seasonal habitats. Proceedings of the Royal Society B: Biological Sciences 277:1259-1266. https://doi.org/10.1098/ rspb.2009.1525

Both, C., and M. E. Visser. 2001. Adjustment to climate change is constrained by arrival date in a long-distance migrant bird. Nature 411:296-298. http://dx.doi.org/10.1038/35077063

Bottrill, M. C., L. N. Joseph, J. Carwardine, M. Bode, C. Cook, E. T. Game, H. Grantham, S. Kark, S. Linke, E. McDonaldMadden, R. L. Pressey, S. Walker, K. A. Wilson, and H. P. Possingham. 2008. Is conservation triage just smart decision making? Trends in Ecology \& Evolution 23:649-654. http://dx.doi. org/10.1016/j.tree.2008.07.007

Boulanger, Y., S. Gauthier, and P. J. Burton. 2014. A refinement of models projecting future Canadian fire regimes using homogeneous fire regime zones. Canadian Journal of Forest Research 44:365-376. http://dx.doi.org/10.1139/cjfr-2013-0372

Boulanger, Y., D. R. Gray, B. J. Cooke, and L. De Grandpré. 2016. Model-specification uncertainty in future forest pest outbreak. Global Change Biology 22:1595-1607. http://dx.doi.org/10.1111/ gcb. 13142

Boulanger, Y., A. R. Taylor, D. T. Price, D. Cyr, E. McGarrigle, W. Rammer, G. Sainte-Marie, A. Beaudoin, L. Guindon, and N. Mansuy. 2017. Climate change impacts on forest landscapes along the Canadian southern boreal forest transition zone. Landscape Ecology 32:1415-1431. http://dx.doi.org/10.1007/s10980-016-0421-7

Brandt, J. P., M. D. Flannigan, D. G. Maynard, I. D. Thompson, and W. J. A. Volney. 2013. An introduction to Canada's boreal zone: ecosystem processes, health, sustainability, and environmental issues. Environmental Reviews 21:207-226. http:// dx.doi.org/10.1139/er-2013-0040

Cadieux, P., Y. Boulanger, D. Cyr, A. R. Taylor, D. T. Price, and J. A. Tremblay. 2019. Spatially explicit climate change projections for the recovery planning of threatened species: the Bicknell's Thrush (Catharus Bicknelli) as a case study. Global Ecology and Conservation 17:e0530. http://dx.doi.org/10.1016/j.gecco.2019. e00530

Carroll, C., J. R. Dunk, and A. Moilanen. 2010. Optimizing resiliency of reserve networks to climate change: multispecies conservation planning in the Pacific Northwest, USA. Global Change Biology 16:891-904. https://doi.org/10.1111/

j.1365-2486.2009.01965.x

Carroll, C., S. A. Parks, S. Z. Dobrowski, and D. R. Roberts. 2018. Climatic, topographic, and anthropogenic factors determine connectivity between current and future climate analogs in North America. Global Change Biology 24:5318-5331. http://dx.doi. org/10.1111/gcb.14373

Carroll, C., D. R. Roberts, J. L. Michalak, J. J. Lawler, S. E. Nielsen, D. Stralberg, A. Hamann, B. H. McRae, and T. Wang. 2017. Scale-dependent complementarity of climatic velocity and environmental diversity for identifying priority areas for conservation under climate change. Global Change Biology 23:4508-4520. http://dx.doi.org/10.1111/gcb.13679

Case, M. J., and J. J. Lawler. 2016. Relative vulnerability to climate change of trees in western North America. Climatic Change 136:367-379. http://dx.doi.org/10.1007/s10584-016-1608-2

Committee on the Status of Endangered Wildlife in Canada (COSEWIC). 2009. Bicknell's Thrush (Catharus bicknelli): COSEWIC assessment and status report 2009. COSEWIC, Ottawa, Ontario, Canada. [online] URL: https://www.canada.ca/ en/environment-climate-change/services/species-risk-public-registry/ cosewic-assessments-status-reports/bicknells-thrush-2009.html

Connolly, V., G. Seutin, J.-P. L. Savard, and G. Rompré. 2002. Habitat use by the Bicknell's Thrush in the Estrie Region, Quebec. Wilson Bulletin 114:333-341. http://dx.doi.org/10.1676/0043-5643 (2002)114[0333:HUBTBT]2.0.CO;2

Cushman, S. A., D. McKenzie, D. L. Peterson, J. Littell, and K. S. McKelvey. 2007. Research agenda for integrated landscape modeling. U.S. Forest Service General Technical Report RMRS-194. Rocky Mountain Research Station, Fort Collins, Colorado, USA. [online] URL: https://www.fs.usda.gov/ treesearch/pubs/27437

D'Orangeville, L., L. Duchesne, D. Houle, D. Kneeshaw, B. Côté, and N. Pederson. 2016. Northeastern North America as a potential refugium for boreal forests in a warming climate. Science 352:1452-1455. http://dx.doi.org/10.1126/science.aaf4951

Dawson, T. P., S. T. Jackson, J. I. House, I. C. Prentice, and G. M. Mace. 2011. Beyond predictions: biodiversity conservation in a changing climate. Science 332:53-58. http://dx.doi.org/10.1126/ science. 1200303

De Cáceres, M., L. Brotons, N. Aquilué, and M.-J. Fortin. 2013. The combined effects of land-use legacies and novel fire regimes on bird distributions in the Mediterranean. Journal of Biogeography 40:1535-1547. http://dx.doi.org/10.1111/jbi.12111

DeLuca, W. V., and D. I. King. 2017. Montane birds shift downslope despite recent warming in the northern Appalachian Mountains. Journal of Ornithology 158:493-505. http://dx.doi. org/10.1007/s10336-016-1414-7

Desrochers, A., and B. Drolet. 2017. Le Programme de surveillance des oiseaux nicheurs de la Forêt Montmorency: une nouvelle source de tendances des populations d'oiseaux nicheurs pour la forêt boréale au Québec. Le Naturaliste canadien 141:61-74. https://doi.org/10.7202/1039737ar

Dobrowski, S. Z. 2011. A climatic basis for microrefugia: the influence of terrain on climate. Global Change Biology 17:1022-1035. https://doi.org/10.1111/j.1365-2486.2010.02263.x

Drapeau, P., A. Leduc, J.-F. Giroux, J.-P. L. Savard, Y. Bergeron, and W. L. Vickery. 2000. Landscape-scale disturbances and changes in bird communities of boreal mixed-wood forests. Ecological Monographs 70:423-444. http://dx.doi.org/10.1890/0012-9615 (2000)070[0423:LSDACI]2.0.CO;2

Drever, M. C., R. G. Clark, C. Derksen, S. M. Slattery, P. Toose, and T. D. Nudds. 2012. Population vulnerability to climate change 
linked to timing of breeding in boreal ducks. Global Change Biology 18:480-492. https://doi.org/10.1111/j.1365-2486.2011.02541. $\mathrm{x}$

Environment and Climate Change Canada. 2013. Bird conservation regions and strategies. Environment and Climate Change Canada, Gatineau, Québec, Canada. [online] URL: https://www.canada.ca/en/environment-climate-change/services/migratorybird-conservation/regions-strategies.html

Environment and Climate Change Canada. 2016. Recovery strategy for the Bicknell's Thrush (Catharus bicknelli) in Canada [Proposed]. Species at Risk Recovery Strategy Series, Environment and Climate Change Canada, Gatineau, Québec, Canada.

Environment and Climate Change Canada. 2017. North American Breeding Bird Survey - Canadian Trends web site, Data-version 2015. Environment and Climate Change Canada, Gatineau, Québec, Canada. [online] URL: https://wildlife-species.canada. ca/breeding-bird-survey-results

Erskine, A. J. 1977. Birds in boreal Canada: communities, densities, and adaptations. Canadian Wildlife Service Report 41. Canadian Wildlife Service, Ottawa, Ontario, Canada.

Faaborg, J., R. T. Holmes, A. D. Anders, K. L. Bildstein, K. M. Dugger, S. A. Gauthreaux, P. Heglund, K. A. Hobson, A. E. Jahn, D. H. Johnson, S. C. Latta, D. J. Levey, P. P. Marra, C. L. Merkord, E. Nol, S. I. Rothstein, T. W. Sherry, T. S. Sillett, F. R. Thompson, and N. Warnock. 2010. Conserving migratory land birds in the New World: Do we know enough? Ecological Applications 20:398-418. http://dx.doi.org/10.1890/09-0397.1

Fisichelli, N. A., L. E. Frelich, and P. B. Reich. 2014. Temperate tree expansion into adjacent boreal forest patches facilitated by warmer temperatures. Ecography 37:152-161. http://dx.doi. org/10.1111/j.1600-0587.2013.00197.x

Foden, B. E., and W. B. Young, editors. 2016. IUCN SSC guidelines for assessing species' vulnerability to climate change. International Union for Conservation of Nature, Gland, Switzerland.

Gardali, T., N. E. Seavy, R. T. DiGaudio, and L. A. Comrack. 2012. A climate change vulnerability assessment of California's at-risk birds. PLoS ONE 7:e29507. http://dx.doi.org/10.1371/ journal.pone.0029507

Gauthier, S., P. Bernier, P. J. Burton, J. Edwards, K. Isaac, N. Isabel, K. Jayen, H. Le Goff, and E. A. Nelson. 2014. Climate change vulnerability and adaptation in the managed Canadian boreal forest. Environmental Reviews 22:256-285. http://dx.doi. org/10.1139/er-2013-0064

Gauthier, S., P. Bernier, T. Kuuluvainen, A. Z. Shvidenko, and D. G. Schepaschenko. 2015. Boreal forest health and global change. Science 349:819-822. http://dx.doi.org/10.1126/science.aaa9092

Gibson, D. D., and J. J. Withrow. 2015. Inventory of the species and subspecies of Alaska birds, second edition. Western Birds 46:94-185.

Gillson, L., T. P. Dawson, S. Jack, and M. A. McGeoch. 2013. Accommodating climate change contingencies in conservation strategy. Trends in Ecology \& Evolution 28:135-142. http://dx.doi. org/10.1016/j.tree.2012.10.008
Gilroy, J. J., J. A. Gill, S. H. M. Butchart, V. R. Jones, and A. M. A. Franco. 2016. Migratory diversity predicts population declines in birds. Ecology Letters 19:308-317. http://dx.doi.org/10.1111/ ele. 12569

Gray, L. K., T. Gylander, M. Mbogga, P.-Y. Chen, and A. Hamann. 2011. Assisted migration to address climate change: recommendations for aspen reforestation in western Canada. Ecological Applications 21:1591-1603. http://dx.doi.org/10.1890/10-1054.1

Gray, L. K., and A. Hamann. 2011. Strategies for reforestation under uncertain future climates: guidelines for Alberta, Canada. PLoS ONE 6:e22977. http://dx.doi.org/10.1371/journal.pone.0022977

Greenberg, R., and S. M. Matsuoka. 2010. Special section: rangewide ecology of the declining Rusty Blackbird: mysteries of a species in decline. Condor 112:770-777. http://dx.doi. org/10.1525/cond.2010.100153

Gregory, R. D., S. G. Willis, F. Jiguet, P. Voříšek, A. Klvaňová, A. van Strien, B. Huntley, Y. Collingham, D. Couvet, and R. E. Green. 2009. An indicator of the impact of climate change on European bird populations. PLOS ONE 4:e4678. https://doi. org/10.1371/journal.pone.0004678

Griffith, B., J. M. Scott, J. W. Carpenter, and C. Reed. 1989. Translocation as a species conservation tool: status and strategy. Science 245:477-480. http://doi.org/10.1126/science.245.4917.477

Grinde, A. R., and G. J. Niemi. 2016. Influence of landscape, habitat, and species co-occurrence on occupancy dynamics of Canada Warblers. Condor 118:513-531. http://dx.doi.org/10.1650/ CONDOR-15-168.1

Groves, C. R., E. T. Game, M. G. Anderson, M. Cross, C. Enquist, Z. Ferdaña, E. Girvetz, A. Gondor, K. R. Hall, J. Higgins, R. Marshall, K. Popper, S. Schill, and S. L. Shafer. 2012. Incorporating climate change into systematic conservation planning. Biodiversity and Conservation 21:1651-1671. http://dx. doi.org/10.1007/s10531-012-0269-3

Halpin, P. N. 1997. Global climate change and natural-area protection: management responses and research directions. Ecological Applications 7:828-843. http://dx.doi.org/10.1890/1051-0761 (1997)007[0828:GCCANA]2.0.CO;2

Hamann, A., D. Roberts, Q. Barber, C. Carroll, and S. Nielsen. 2014. Velocity of climate change algorithms for guiding conservation and management. Global Change Biology 21:997-1004. https://doi.org/10.1111/gcb.12736

Hannah, L., L. Flint, A. D. Syphard, M. A. Moritz, L. B. Buckley, and I. M. McCullough. 2014. Fine-grain modeling of species' response to climate change: holdouts, stepping-stones, and microrefugia. Trends in Ecology \& Evolution 29:390-397. http:// dx.doi.org/10.1016/j.tree.2014.04.006

Hansen, L., J. Hoffman, C. Drews, and E. Mielbrecht. 2010. Designing climate-smart conservation: guidance and case studies. Conservation Biology 24:63-69. http://dx.doi.org/10.1111/ j.1523-1739.2009.01404.X

Heller, N. E., and E. S. Zavaleta. 2009. Biodiversity management in the face of climate change: a review of 22 years of recommendations. Biological Conservation 142:14-32. http://dx. doi.org/10.1016/j.biocon.2008.10.006 
Hobson, K. A., A. G. Wilson, S. L. Van Wilgenburg, and E. M. Bayne. 2013. An estimate of nest loss in Canada due to industrial forestry operations. Avian Conservation and Ecology 8(2):5. http:// dx.doi.org/10.5751/ace-00583-080205

Hodgson, J. A., C. D. Thomas, B. A. Wintle, and A. Moilanen. 2009. Climate change, connectivity and conservation decision making: back to basics. Journal of Applied Ecology 46:964-969. http://dx.doi.org/10.1111/j.1365-2664.2009.01695.x

Hoegh-Guldberg, O., L. Hughes, S. McIntyre, D. B. Lindenmayer, C. Parmesan, H. P. Possingham, and C. D. Thomas. 2008. Assisted colonization and rapid climate change. Science 321:345-346. http://dx.doi.org/10.1126/science.1157897

Hogg, E. H., and P. Y. Bernier. 2005. Climate change impacts on drought-prone forests in western Canada. Forestry Chronicle 81:675-682. http://dx.doi.org/10.5558/tfc81675-5

Hunt, A. R., E. M. Bayne, and S. Haché. 2017. Forestry and conspecifics influence Canada Warbler (Cardellina canadensis) habitat use and reproductive activity in boreal Alberta, Canada. Condor 119:832-847. http://dx.doi.org/10.1650/CONDOR-17-35.1

Jackson, S. T., and D. F. Sax. 2010. Balancing biodiversity in a changing environment: extinction debt, immigration credit and species turnover. Trends in Ecology \& Evolution 25:153-160. http:// dx.doi.org/10.1016/j.tree.2009.10.001

Johnson, D. H., and J. W. Grier. 1988. Determinants of breeding distributions of ducks. Wildlife Monographs 100:1-37.

Keith, D. A., H. R. Akçakaya, W. Thuiller, G. F. Midgley, R. G. Pearson, S. J. Phillips, H. M. Regan, M. B. Araújo, and T. G. Rebelo. 2008. Predicting extinction risks under climate change: coupling stochastic population models with dynamic bioclimatic habitat models. Biology Letters 4:560-563. https://doi. org/10.1098/rsbl.2008.0049

Keppel, G., K. P. Van Niel, G. W. Wardell-Johnson, C. J. Yates, M. Byrne, L. Mucina, A. G. T. Schut, S. D. Hopper, and S. E. Franklin. 2012. Refugia: identifying and understanding safe havens for biodiversity under climate change. Global Ecology and Biogeography 21:393-404. http://dx.doi.org/10.1111/ j.1466-8238.2011.00686.x

Krawchuk, M. A., S. L. Haire, J. Coop, M.-A. Parisien, E. Whitman, G. Chong, and C. Miller. 2016. Topographic and fire weather controls of fire refugia in forested ecosystems of northwestern North America. Ecosphere 7:e01632. http://dx.doi. org/10.1002/ecs2.1632

Kujala, H., A. Moilanen, M. B. Araújo, and M. Cabeza. 2013. Conservation planning with uncertain climate change projections. PLOS ONE 8:e53315. http://dx.doi.org/10.1371/ journal.pone.0053315

Lambert, J. D., and K. P. McFarland. 2004. Projecting effects of climate change on Bicknell's Thrush habitat in the northeastern United States. Greene County Soil and Water Conservation District. [online] URL: http://dspace.gcswcd.com/handle/123456789/120

Langham, G. M., J. G. Schuetz, T. Distler, C. U. Soykan, and C. Wilsey. 2015. Conservation status of North American birds in the face of future climate change. PLOS ONE 10:e135350. http://dx. doi.org/10.1371/journal.pone. 0135350
Lawler, J. J., D. D. Ackerly, C. M. Albano, M. G. Anderson, S. Z. Dobrowski, J. L. Gill, N. E. Heller, R. L. Pressey, E. W. Sanderson, and S. B. Weiss. 2015. The theory behind, and the challenges of, conserving nature's stage in a time of rapid change. Conservation Biology 29:618-629. http://dx.doi.org/10.1111/cobi.12505

Lawton, J. H. 1993. Range, population abundance and conservation. Trends in Ecology and Evolution 8:409-413. http:// dx.doi.org/10.1016/0169-5347(93)90043-O

Lee, P., J. D. Gysbers, and Z. Stanojevic. 2006. Canada's forest landscape fragments: a first approximation. Global Forest Watch Canada, Edmonton, Alberta, Canada.

Lemoine, N., H.-C. Schaefer, and K. Böhning-Gaese. 2007. Species richness of migratory birds is influenced by global climate change. Global Ecology and Biogeography 16:55-64. http://dx.doi. org/doi:10.1111/j.1466-8238.2006.00252.x

Lenoir, J., and J. C. Svenning. 2015. Climate-related range shifts - a global multidimensional synthesis and new research directions. Ecography 38:15-28. http://dx.doi.org/10.1111/ecog.00967

Leroux, S. J., F. K. A. Schmiegelow, R. B. Lessard, and S. G. Cumming. 2007. Minimum dynamic reserves: a framework for determining reserve size in ecosystems structured by large disturbances. Biological Conservation 138:464-473. https://doi. org/10.1016/j.biocon.2007.05.012

Loarie, S. R., P. B. Duffy, H. Hamilton, G. P. Asner, C. B. Field, and D. D. Ackerly. 2009. The velocity of climate change. Nature 462:1052-1055. http://dx.doi.org/10.1038/nature08649

Loyola, R. D., P. Lemes, J. C. Nabout, J. Trindade-Filho, M. D. Sagnori, R. Dobrovolski, and J. A. F. Diniz-Filho. 2013. A straightforward conceptual approach for evaluating spatial conservation priorities under climate change. Biodiversity \& Conservation 22:483-495. http://dx.doi.org/10.1007/s10531-012-0424$\mathrm{x}$

Machtans, C. S., K. J. Kardynal, and P. A. Smith. 2014. How well do regional or national Breeding Bird Survey data predict songbird population trends at an intact boreal site? Avian Conservation and Ecology 9(1):5. http://dx.doi.org/10.5751/ ace-00649-090105

Magness, D. R., A. L. Sesser, and T. Hammond. 2018. Using topographic geodiversity to connect conservation lands in the Central Yukon, Alaska. Landscape Ecology 33:547-556. http://dx. doi.org/10.1007/s10980-018-0617-0

Mahon, C. L., G. Holloway, P. Sólymos, S. G. Cumming, E. M. Bayne, F. K. A. Schmiegelow, and S. J. Song. 2016. Community structure and niche characteristics of upland and lowland western boreal birds at multiple spatial scales. Forest Ecology and Management 361:99-116. http://dx.doi.org/10.1016/j.foreco.2015.11.007

Marcot, B. G., M. T. Jorgenson, J. P. Lawler, C. M. Handel, and A. R. DeGange. 2015. Projected changes in wildlife habitats in Arctic natural areas of northwest Alaska. Climatic Change 130:145-154. http://dx.doi.org/10.1007/s10584-015-1354-x

Margules, C. R., and R. L. Pressey. 2000. Systematic conservation planning. Nature 405:243-253. http://dx.doi.org/10.1038/35012251 
Marra, P. P., E. B. Cohen, S. R. Loss, J. E. Rutter, and C. M. Tonra. 2015. A call for full annual cycle research in animal ecology. Biology Letters 11:20150552. https://doi.org/10.1098/rsbl.2015.0552

Marra, P. P., K. A. Hobson, and R. T. Holmes. 1998. Linking winter and summer events in a migratory bird by using stablecarbon isotopes. Science 282:1884-1886. http://doi.org/10.1126/ science.282.5395.1884

Mayor, S. J., R. P. Guralnick, M. W. Tingley, J. Otegui, J. C. Withey, S. C. Elmendorf, M. E. Andrew, S. Leyk, I. S. Pearse, and D. C. Schneider. 2017. Increasing phenological asynchrony between spring green-up and arrival of migratory birds. Scientific Reports 7:1902. http://dx.doi.org/10.1038/s41598-017-02045-Z

McClure, C. J. W., B. W. Rolek, K. McDonald, and G. E. Hill. 2012. Climate change and the decline of a once common bird. Ecology \& Evolution 2:370-378. https://doi.org/10.1002/ece3.95

McDonald-Madden, E., P. W. J. Baxter, and H. P. Possingham. 2008. Subpopulation triage: how to allocate conservation effort among populations. Conservation Biology 22:656-665. http://dx. doi.org/10.1111/j.1523-1739.2008.00918.x

McIntyre, S., G. W. Barrett, R. L. Kitching, and H. F. Recher. 1992. Species triage-seeing beyond wounded rhinos. Conservation Biology 6:604-606. http://dx.doi.org/10.1046/ j.1523-1739.1992.06040604.x

McLachlan, J. S., J. J. Hellmann, and M. W. Schwartz. 2007. A framework for debate of assisted migration in an era of climate change. Conservation Biology 21:297-302. https://doi.org/10.1111/ j.1523-1739.2007.00676.x

McLaughlin, B. C., D. D. Ackerly, P. Z. Klos, J. Natali, T. E. Dawson, and S. E. Thompson. 2017. Hydrologic refugia, plants, and climate change. Global Change Biology 23:2941-2961. http:// dx.doi.org/10.1111/gcb.13629

Meehl, G. A., C. Covey, T. Delworth, M. Latif, B. McAvaney, J. F. B. Mitchell, R. J. Stouffer, and K. E. Taylor. 2007. The WCRP CMIP3 multi-model dataset: a new era in climate change research. Bulletin of the American Meteorological Society 88:1383-1394. https://doi.org/10.1175/BAMS-88-9-1383

Michalak, J. L., J. J. Lawler, D. R. Roberts, and C. Carroll. 2018. Distribution and protection of climatic refugia in North America. Conservation Biology 32:1414-1425. http://dx.doi.org/doi:10.1111/ cobi. 13130

Millar, C. I., N. L. Stephenson, and S. L. Stephens. 2007. Climate change and forests of the future: managing in the face of uncertainty. Ecological Applications 17:2145-2151. https://doi. org/10.1890/06-1715.1

Moilanen, A. 2007. Landscape zonation, benefit functions and target-based planning: unifying reserve selection strategies. Biological Conservation 134:571-579. https://doi.org/10.1016/j. biocon.2006.09.008

Morelli, T. L., C. Daly, S. Z. Dobrowski, D. M. Dulen, J. L. Ebersole, S. T. Jackson, J. D. Lundquist, C. I. Millar, S. P. Maher, W. B. Monahan, K. R. Nydick, K. T. Redmond, S. C. Sawyer, S. Stock, and S. R. Beissinger. 2016. Managing climate change refugia for climate adaptation. PLoS ONE 11:e159909. http:// dx.doi.org/10.1371/journal.pone.0159909
Naujokaitis-Lewis, I. 2014. Influence of climatic and non-climatic factors on range dynamics and conservation priorities of longdistance migratory birds. Dissertation. University of Toronto, Toronto, Ontario, Canada.

Naujokaitis-Lewis, I. R., J. M. R. Curtis, L. Tischendorf, D. Badzinski, K. Lindsay, and M.-J. Fortin. 2013. Uncertainties in coupled species distribution-metapopulation dynamics models for risk assessments under climate change. Diversity and Distributions 19:541-554. http://dx.doi.org/10.1111/ddi.12063

Nielsen, S., E. DeLancey, K. Reinhardt, and M.-A. Parisien. 2016. Effects of lakes on wildfire activity in the boreal forests of Saskatchewan, Canada. Forests 7(11):265. https://doi.org/10.3390/ f7110265

Niemi, G., J. Hanowsk, P. Helle, R. Howe, M. Mönkkönen, L. Venier, and D. Welsh. 1998. Ecological sustainability of birds in boreal forests. Conservation Ecology 2(2):17. http://dx.doi. org/10.5751/ES-00079-020217

Nixon, A. E., R. J. Fisher, D. Stralberg, E. M. Bayne, and D. Farr. 2016. Projected responses of North American grassland songbirds to climate change and habitat availability at their northern range limits in Alberta, Canada. Avian Conservation and Ecology 11(2):2. http://dx.doi.org/10.5751/ACE-00866-110202

Norris, D. R., and C. M. Taylor. 2005. Predicting the consequences of carry-over effects for migratory populations. Biology Letters 2:148-151. http://dx.doi.org/10.1098/rsbl.2005.0397

Noss, R. F. 2001. Beyond Kyoto: forest management in a time of rapid climate change. Conservation Biology 15:578-590. http://dx. doi.org/10.1046/j.1523-1739.2001.015003578.x

Pacifici, M., W. B. Foden, P. Visconti, J. E. M. Watson, S. H. M. Butchart, K. M. Kovacs, B. R. Scheffers, D. G. Hole, T. G. Martin, H. R. Akçakaya, R. T. Corlett, B. Huntley, D. Bickford, J. A. Carr, A. A. Hoffmann, G. F. Midgley, P. Pearce-Kelly, R. G. Pearson, S. E. Williams, S. G. Willis, B. Young, and C. Rondinini. 2015. Assessing species vulnerability to climate change. Nature Climate Change 5:215-224. http://dx.doi.org/10.1038/nclimate2448

Pasher, J., E. Seed, and J. Duffe. 2013. Development of boreal ecosystem anthropogenic disturbance layers for Canada based on 2008 to 2010 Landsat imagery. Canadian Journal of Remote Sensing 39:42-58. http://dx.doi.org/10.5589/m13-007

Potapov, P., M. C. Hansen, L. Laestadius, S. Turubanova, A. Yaroshenko, C. Thies, W. Smith, I. Zhuravleva, A. Komarova, S. Minnemeyer, and E. Esipova. 2017. The last frontiers of wilderness: tracking loss of intact forest landscapes from 2000 to 2013. Science Advances 3:e1600821. http://doi.org/10.1126/ sciadv. 1600821

Powers, R. P., N. C. Coops, V. J. Tulloch, S. E. Gergel, T. A. Nelson, and M. A. Wulder. 2017. A conservation assessment of Canada's boreal forest incorporating alternate climate change scenarios. Remote Sensing in Ecology and Conservation 3:202-216. http://dx. doi.org/10.1002/rse2.34

Price, D. T., R. I. Alfaro, K. J. Brown, M. D. Flannigan, R. A. Fleming, E. H. Hogg, M. P. Girardin, T. Lakusta, M. Johnston, D. W. McKenney, J. H. Pedlar, T. Stratton, R. N. Sturrock, I. D. Thompson, J. A. Trofymow, and L. A. Venier. 2013. Anticipating 
the consequences of climate change for Canada's boreal forest ecosystems. Environmental Reviews 21:322-365. https://doi. org/10.1139/er-2013-0042

Ralston, J., W. V. DeLuca, R. E. Feldman, and D. I. King. 2017. Population trends influence species ability to track climate change. Global Change Biology 23:1390-1399. http://dx.doi. org/10.1111/gcb.13478

Ralston, J., and J. J. Kirchman. 2013. Predicted range shifts in North American boreal forest birds and the effect of climate change on genetic diversity in Blackpoll Warblers (Setophaga striata). Conservation Genetics 14:543-555. http://dx.doi. org/10.1007/s10592-012-0418-y

Rehfeldt, G. E., N. L. Crookston, C. Sáenz-Romero, and E. M. Campbell. 2012. North American vegetation model for land-use planning in a changing climate: a solution to large classification problems. Ecological Applications 22:119-141. http://dx.doi. org/10.1890/11-0495.1

Ricciardi, A., and D. Simberloff. 2009. Assisted colonization is not a viable conservation strategy. Trends in Ecology \& Evolution 24:248-253. http://dx.doi.org/10.1016/j.tree.2008.12.006

Rodenhouse, N. L., L. M. Christenson, D. Parry, and L. E. Green. 2009. Climate change effects on native fauna of northeastern forests. Canadian Journal of Forest Research 39:249-263. http:// dx.doi.org/10.1139/X08-160

Rodenhouse, N. L., S. N. Matthews, K. P. McFarland, J. D. Lambert, L. R. Iverson, A. Prasad, T. S. Sillett, and R. T. Holmes. 2008. Potential effects of climate change on birds of the Northeast. Mitigation and Adaptation Strategies for Global Change 13:517-540-540. http://dx.doi.org/10.1007/s11027-007-9126-1

Root, T. L., and S. H. Schneider. 2006. Conservation and climate change: the challenges ahead. Conservation Biology 20:706-708. https://doi.org/10.1111/j.1523-1739.2006.00465.x

Rose, N.-A., and P. J. Burton. 2009. Using bioclimatic envelopes to identify temporal corridors in support of conservation planning in a changing climate. Forest Ecology and Management 258S:S64-S74. https://doi.org/10.1016/j.foreco.2009.07.053

Rosenberg, K. V., J. A. Kennedy, R. Dettmers, R. P. Ford, D. Reynolds, J. D. Alexander, C. J. Beardmore, P. J. Blancher, R. E. Bogart, G. S. Butcher, A. F. Camfield, A. Couturier, D. W. Demarest, W. E. Easton, J. J. Giocomo, R. H. Keller, A. E. Mini, A. O. Panjabi, D. N. Pashley, T. D. Rich, J. M. Ruth, H. Stabins, J. Stanton, and T. Will. 2016. Partners in Flight Landbird Conservation Plan: 2016 Revision for Canada and Continental United States. Partners in Flight Science Committee. [online] URL: https://www.partnersinflight.org/what-we-do/science/plans/

Rowland, E. L., N. Fresco, D. Reid, and H. A. Cooke. 2016. Examining climate-biome ("cliome") shifts for Yukon and its protected areas. Global Ecology and Conservation 8:1-17. http:// dx.doi.org/10.1016/j.gecco.2016.07.006

Rupp, T. S., M. Olson, L. G. Adams, B. W. Dale, K. Joly, J. Henkelman, W. B. Collins, and A. M. Starfield. 2006. Simulating the influences of various fire regimes on caribou winter habitat. Ecological Applications 16:1730-1743. http://dx.doi.org/10.1890/1051-0761 (2006)016[1730:STIOVF]2.0.CO;2
Rupp, T. S., A. M. Starfield, and F. S. Chapin III. 2000. A framebased spatially explicit model of subarctic vegetation response to climatic change: comparison with a point model. Landscape Ecology 15:383-400. http://dx.doi.org/10.1023/a:1008168418778

Sæther, B.-E., V. Grøtan, S. Engen, T. Coulson, P. R. Grant, M. E. Visser, J. E. Brommer, B. R. Grant, L. Gustafsson, B. J. Hatchwell, K. Jerstad, P. Karell, H. Pietiäinen, A. Roulin, O. W. Røstad, and H. Weimerskirch. 2016. Demographic routes to variability and regulation in bird populations. Nature Communications 7:12001. http://dx.doi.org/10.1038/ncomms12001

Sandel, B., L. Arge, B. Dalsgaard, R. G. Davies, K. J. Gaston, W. J. Sutherland, and J.-C. Svenning. 2011. The influence of late quaternary climate-change velocity on species endemism. Science 334:660-664. http://dx.doi.org/10.1126/science.1210173

Scheffer, M., M. Hirota, M. Holmgren, E. H. Van Nes, and F. S. Chapin III. 2012. Thresholds for boreal biome transitions. Proceedings of the National Academy of Sciences 109:21384-21389. https://doi.org/10.1073/pnas.1219844110

Scheller, R. M., J. B. Domingo, B. R. Sturtevant, J. S. Williams, A. Rudy, E. J. Gustafson, and D. J. Mladenoff. 2007. Design, development, and application of LANDIS-II, a spatial landscape simulation model with flexible spatial and temporal resolution. Ecological Modelling 201:409-419. https://doi.org/10.1016/j. ecolmodel.2006.10.009

Scheller, R. M., and D. J. Mladenoff. 2004. A forest growth and biomass module for a landscape simulation model, LANDIS: design, validation, and application. Ecological Modelling 180:211-229. https://doi.org/10.1016/j.ecolmodel.2004.01.022

Schmiegelow, F. K. A., S. G. Cumming, K. A. Lisgo, S. J. Leroux, and M. A. Krawchuk. 2014. Catalyzing large landscape conservation in Canada's boreal systems: the BEACONs project experience. Pages 97-122 in J. N. Levitt, editor. Conservation catalysts. Lincoln Institute of Land Policy, Cambridge, Massachusetts, USA.

Schmiegelow, F. K. A., C. S. Machtans, and S. J. Hannon. 1997. Are boreal birds resilient to forest fragmentation? An experimental study of short-term community responses. Ecology 78:1914-1932. http://dx.doi.org/10.1890/0012-9658(1997)078[1914: ABBRTF]2.0.CO;2

Schmiegelow, F. K. A., and M. Mönkkönen. 2002. Habitat loss and fragmentation in dynamic landscapes: avian perspectives from the boreal forest. Ecological Applications 12:375-389.

Schneider, R. R., K. DeVito, N. Kettridge, and E. Bayne. 2016. Moving beyond bioclimatic envelope models: integrating upland forest and peatland processes to predict ecosystem transitions under climate change in the western Canadian boreal plain. Ecohydrology 9:899-908. http://dx.doi.org/10.1002/eco.1707

Selwood, K. E., J. R. Thomson, R. H. Clarke, M. A. McGeoch, and R. Mac Nally. 2015. Resistance and resilience of terrestrial birds in drying climates: do floodplains provide drought refugia? Global Ecology and Biogeography:838-848. http://dx.doi. org/10.1111/geb.12305

Slattery, S. M., J. I. Morrisette, G. G. Mack, and E. W. Butterworth. 2011. Waterfowl conservation planning: science 
needs and approaches. Pages 23-40 in J. V. Wells, editor. Boreal birds of North America: a hemispheric view of their conservation links and significance. Studies in Avian Biology 41. University of California Press, Berkeley, California, USA.

Small-Lorenz, S. L., L. A. Culp, T. B. Ryder, T. C. Will, and P. P. Marra. 2013. A blind spot in climate change vulnerability assessments. Nature Climate Change 3:91-93. http://dx.doi. org/10.1038/nclimate1810

Stralberg, D., E. M. Bayne, S. G. Cumming, P. Sólymos, S. J. Song, and F. K. A. Schmiegelow. 2015b. Conservation of future boreal forest bird communities considering lags in vegetation response to climate change: a modified refugia approach. Diversity and Distributions 21:1112-1128. http://dx.doi.org/10.1111/ddi.12356

Stralberg, D., A. Camfield, M. Carlson, C. Lauzon, A. Westwood, N. K. S. Barker, S. J. Song. and F. K. A. Schmiegelow. $2018 c$. Strategies for identifying priority areas for passerine conservation in Canada's boreal forest. Avian Conservation and Ecology 13 (2):12. https://doi.org/10.5751/ACE-01303-130212

Stralberg, D., C. Carroll, J. H. Pedlar, C. B. Wilsey, D. W. McKenney, and S. E. Nielsen. 2018a. Macrorefugia for North American trees and songbirds: climatic limiting factors and multiscale topographic influences. Global Ecology and Biogeography 27:690-703. http://dx.doi.org/10.1111/geb.12731

Stralberg, D., S. M. Matsuoka, A. Hamann, E. M. Bayne, P. Sólymos, F. K. A. Schmiegelow, X. Wang, S. G. Cumming, and S. J. Song. 2015a. Projecting boreal bird responses to climate change: the signal exceeds the noise. Ecological Applications 25:52-69. http://dx.doi.org/10.1890/13-2289.1

Stralberg, D., S. M. Matsuoka, C. M. Handel, F. K. A. Schmiegelow, A. Hamann, and E. M. Bayne. 2017. Biogeography of boreal passerine range dynamics: past, present, and future. Ecography 40:1050-1066. http://dx.doi.org/10.1111/ecog.02393

Stralberg, D., X. Wang, M.-A. Parisien, F.-N. Robinne, P. Sólymos, C. L. Mahon, S. E. Nielsen, and E. M. Bayne. $2018 b$. Wildfire-mediated vegetation change in boreal forests of Alberta, Canada. Ecosphere 9:e02156. http://dx.doi.org/10.1002/ecs2.2156

Strong, C., B. Zuckerberg, J. L. Betancourt, and W. D. Koenig. 2015. Climatic dipoles drive two principal modes of North American boreal bird irruption. Proceedings of the National Academy of Sciences 112:E2795-E2802. http://dx.doi.org/10.1073/ pnas. 1418414112

Theobald, D. M., D. Harrison-Atlas, W. B. Monahan, and C. M. Albano. 2015. Ecologically-relevant maps of landforms and physiographic diversity for climate adaptation planning. PLoS ONE 10:e0143619. http://dx.doi.org/10.1371/journal.pone.0143619

Thomas, G. H., R. B. Lanctot, and T. Székely. 2006. Can intrinsic factors explain population declines in North American breeding shorebirds? A comparative analysis. Animal Conservation 9:252-258. https://doi.org/10.1111/j.1469-1795.2006.00029.x

Thompson, C., C. A. Mendoza, and K. J. Devito. 2017. Potential influence of climate change on ecosystems within the Boreal Plains of Alberta. Hydrological Processes 31:2110-2124. http:// dx.doi.org/10.1002/hyp.11183
Townsend, J. M., K. P. McFarland, C. C. Rimmer, W. G. Ellison, and E. J. E. Goetz. 2015. Bicknell's Thrush (Catharus bicknelli), version 2.0. In P. G. Rodewald, editor. The birds of North America. Cornell Lab of Ornithology, Ithaca, New York, USA. https://doi. org/10.2173/bna.592

Tremblay, J. A., J. Ibarzabal, C. Dussault, and J.-P. L. Savard. 2009. Habitat requirements of breeding Black-backed Woodpeckers (Picoides arcticus) in managed, unburned boreal forest. Avian Conservation and Ecology 4(1):2. http://dx.doi. org/10.5751/ACE-00297-040102

Tremblay, J. A., J. Ibarzabal, and J.-P. L. Savard. 2010. Foraging ecology of Black-backed Woodpeckers (Picoides arcticus) in unburned eastern boreal forest stands. Canadian Journal of Forest Research 40:991-999. http://dx.doi.org/10.1139/X10-044

Tremblay, J. A., Y. Boulanger, D. Cyr, A. R. Taylor, D. T. Price, and M.-H. St-Laurent. 2018. Harvesting interacts with climate change to affect future habitat quality of a focal species in eastern Canada's boreal forest. PLoS ONE 13:e191645. http://dx.doi. org/10.1371/journal.pone.0191645

U.S. Environmental Protection Agency. 2009. A framework for categorizing the relative vulnerability of threatened and endangered species to climate change. National Center for Environmental Assessment, Washington, D.C., USA. [online] URL: https:// cfpub.epa.gov/ncea/risk/recordisplay.cfm?deid=203743

Van Wilgenburg, S. L., E. M. Beck, B. Obermayer, T. Joyce, and B. Weddle. 2015. Biased representation of disturbance rates in the roadside sampling frame in boreal forests: implications for monitoring design. Avian Conservation and Ecology 10(2):5. http://dx.doi.org/10.5751/ACE-00777-100205

Van Wilgenburg, S. L., K. A. Hobson, K. J. Kardynal, and E. M. Beck. 2018. Temporal changes in avian abundance in aspendominated boreal mixedwood forests of central Saskatchewan, Canada. Avian Conservation and Ecology 13(1):3. http://dx.doi. org/10.5751/ACE-01145-130103

Veloz, S. D., N. Nur, L. Salas, D. Jongsomjit, J. Wood, D. Stralberg, and G. Ballard. 2013. Modeling climate change impacts on tidal marsh birds: restoration and conservation planning in the face of uncertainty. Ecosphere 4:49. http://dx.doi.org/10.1890/ es12-00341.1

Virkkala, R., and A. Lehikoinen. 2014. Patterns of climateinduced density shifts of species: poleward shifts faster in northern boreal birds than in southern birds. Global Change Biology 20:2995-3003. http://dx.doi.org/10.1111/gcb.12573

Virkkala, R., A. Rajasärkkä, R. K. Heikkinen, S. Kuusela, N. Leikola, and J. Pöyry. 2018. Birds in boreal protected areas shift northwards in the warming climate but show different rates of population decline. Biological Conservation 226:271-279. http:// dx.doi.org/10.1016/j.biocon.2018.08.015

Vissault, S. 2016. Biogéographie et dynamique de la forêt tempérée nordique dans un contexte de changements climatiques. Université du Québec à Rimouski, Québec, Canada.

Waddington, J. M., P. J. Morris, N. Kettridge, G. Granath, D. K. Thompson, and P. A. Moore. 2015. Hydrological feedbacks in northern peatlands. Ecohydrology 8:113-127. http://dx.doi. org/10.1002/eco.1493 
Wade, A. A., B. K. Hand, R. P. Kovach, G. Luikart, D. C. Whited, and C. C. Muhlfeld. 2017. Accounting for adaptive capacity and uncertainty in assessments of species' climate-change vulnerability. Conservation Biology 31:136-149. http://dx.doi. org/10.1111/cobi.12764

Watson, J. E. M., T. Iwamura, and N. Butt. 2013. Mapping vulnerability and conservation adaptation strategies under climate change. Nature Climate Change 3:989-994. http://dx.doi. org/10.1038/nclimate2007

Wells, J., and P. Blancher. 2011. Global role for sustaining bird populations. in J. Wells, editor. Boreal Birds of North America: a hemispheric view of their conservation links and significance. Studies in Avian Biology 41. University of California Press, Berkeley, California, USA.

Williams, M. I., and R. K. Dumroese. 2013. Preparing for climate change: forestry and assisted migration. Journal of Forestry 111:287-297. http://dx.doi.org/10.5849/jof.13-016

Wilson, S., J. F. Saracco, R. Krikun, D. T. T. Flockhart, C. M. Godwin, and K. R. Foster. 2018. Drivers of demographic decline across the annual cycle of a threatened migratory bird. Scientific Reports 8:7316. http://dx.doi.org/10.1038/s41598-018-25633-Z

Young, B. E., E. Byers, G. Hammerson, A. Frances, L. Oliver, and A. Treher. 2016. Guidelines for using the NatureServe Climate Change Vulnerability Index. Release 3.02. NatureServe, Arlington, Virginia, USA. [online] URL: http://www.natureserve. org/conservation-tools/climate-change-vulnerability-index 
Appendix 1. Climate-projected distributional shifts for North American ecoregions

Data available at: http://doi.org/10.5281/zenodo.1407176 and https://adaptwest.databasin.org/pages/ecoregion-displacement-and-refugia

Climate model projections suggest major North American biome shifts in response to anthropogenic climate change (Rehfeldt et al. 2012). Such shifts could have profound influences on native flora and fauna, many of which would have to move long distances to track their climatic niches. To evaluate potential ecosystem changes at a somewhat finer scale, we projected the change in climate space for level III ecoregions (Commission for Environmental Cooperation 1997) as surrogates for multiple associated species and ecological communities. First, we developed a random forest model (Breiman 2001) to predict ecoregion class from bioclimatic variables (Table A1.1), using 1-km interpolated climate data for the 1969-1990 normal period (Hamann et al. 2013), available at http://adaptwest.databasin.org/pages/adaptwest-climatena.

$\mathrm{R}$ Code for this portion follows:

library (randomForest)

library(raster)

$\#$ \#co = project directory

setwd (eco)

datlcc <- read.csv("CECEcoregionSampleLCC.csv")

cececo <- read.csv ("CECecoregions.csv")

LCC <- CRS ("+proj=lcc +lat_1=49 +lat_2=77 +lat_ $\theta=0+10 n_{-} \theta=-95+x \_0=0+y \_0=0+$ ellps=GRS80 +units=m +no_defs")

\#cur = directory containing grids representing derived climate variables setwd(cur)

clim <- list.files(cur, pattern =".asc\$")

curclim<-stack(clim)

temp <- raster (clim[1])

ID <- as.data.frame(rasterToPoints(temp))

names(ID) [3] <- "ID4km"

ID\$ID <- row. names (ID)

IDR <- raster (ncols=ncol (temp), nrows=nrow(temp), $x m n=x m i n(t e m p), x m x=x m a x$ (te mp), ymn=ymin(temp), ymx=ymax(temp))

IDRR <- rasterize(as.matrix $(\operatorname{ID}[, 1: 2])$, IDR, as.numeric $(\operatorname{ID}[, 4]))$

curclim <- addLayer(curclim, IDRR)

setwd (eco)

sampleclim<-cbind(datlcc, extract(curclim, as .matrix(cbind(datlcc [, 3], datlcc [, 4 ]))) (

sc <- na.omit (sampleclim)

names(sc) $[\operatorname{ncol}(\mathrm{sc})]<-$ "IDgrid"

SC \$NA_L3CODE <- as.factor (as.character (sC\$NA_L3CODE))

lu <- as.data.frame(levels (sc\$NA_L3CODE))

lu\$level <- row. names $(l u)$ 


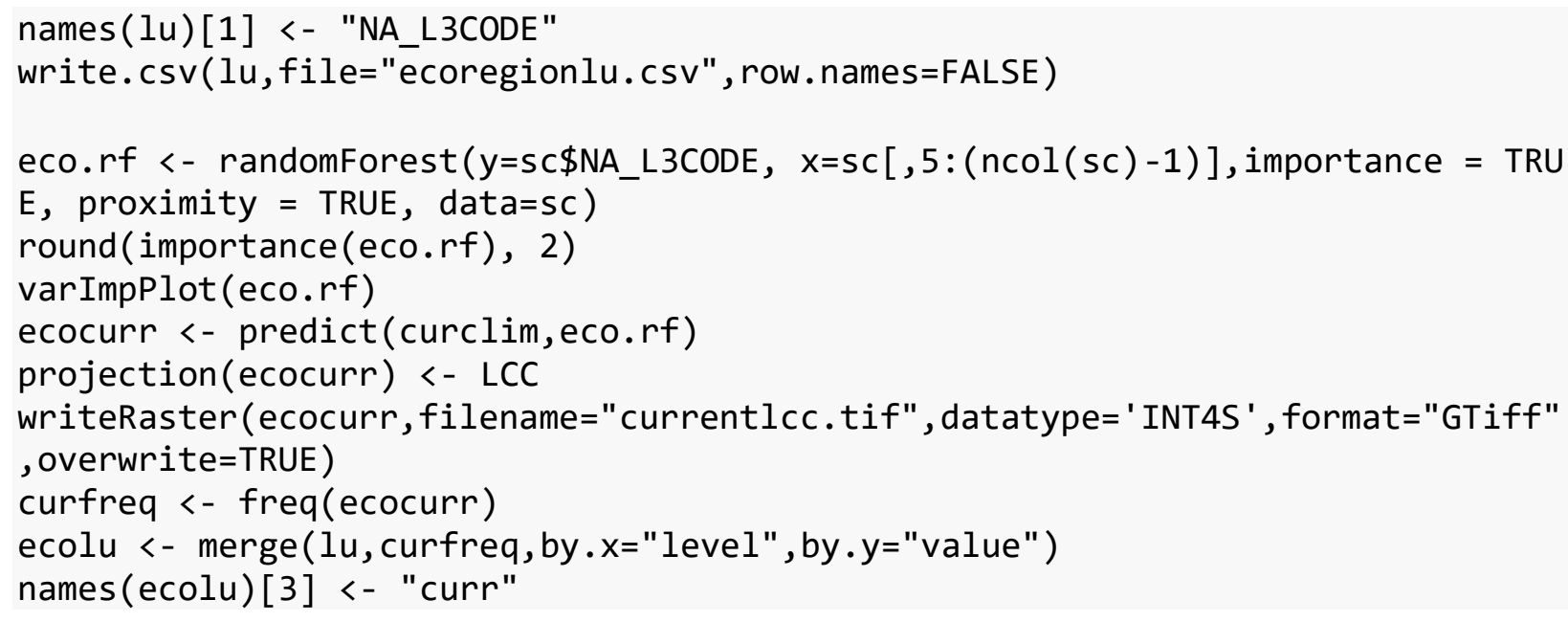

Table A1.1: Bioclimatic variables used as inputs to random forest models (from Hamann et al. 2013)

MAT: mean annual temperature $\left({ }^{\circ} \mathrm{C}\right)$

MWMT: mean temperature of the warmest month $\left({ }^{\circ} \mathrm{C}\right)$

MCMT: mean temperature of the coldest month $\left({ }^{\circ} \mathrm{C}\right)$

TD: difference between MCMT and MWMT, as a measure of continentality $\left({ }^{\circ} \mathrm{C}\right)$

MAP: mean annual precipitation ( $\mathrm{mm}$ )

MSP: mean summer (May to Sep) precipitation (mm)

AHM: annual heat moisture index, calculated as (MAT+10)/(MAP/1000)

SHM: summer heat moisture index, calculated as MWMT/(MSP/1000)

DD0: degree-days below $0^{\circ} \mathrm{C}$ (chilling degree days)

DD5: degree-days above $5^{\circ} \mathrm{C}$ (growing degree days)

DD18: degree-days below $18^{\circ} \mathrm{C}$

DD18: degree-days above $18^{\circ} \mathrm{C}$

NFFD: the number of frost-free days

bFFP: the julian date on which the frost-free period begins

eFFP: the julian date on which the frost-free period ends

FFP: frost-free period

PAS: precipitation as snow $(\mathrm{mm})$

EMT: extreme minimum temperature over 30 years

EXT: extreme maximum temperature over 30 years

Eref: Hargreave's reference evaporation

CMD: Hargreave's climatic moisture index

RH: mean annual relative humidity (\%)

Tavewt: winter (Dec to Feb) mean temperature $\left({ }^{\circ} \mathrm{C}\right)$

Tavesm: summer (Jun to Aug) mean temperature $\left({ }^{\circ} \mathrm{C}\right.$ )

PPTwt: winter (Dec to Feb) precipitation (mm)

PPTsm: summer (Jun to Aug) precipitation (mm) 
This model was then used to project ecoregions onto future mid-century (2041-2070) and end-ofcentury (2071-2100) climate conditions. Climate projections were based on 1-km downscaled climate anomalies (Wang et al. 2016) generated by an ensemble of 15 widely-used global climate models (GCM) from the Coupled Model Intercomparison Project, Phase 5 (CMIP5, Taylor et al. 2012), available at http://adaptwest.databasin.org. We used representative concentration pathway (RCP) 8.5, to represent the 21 st century conditions that are to be expected without dramatic reductions in greenhouse gas emissions or technological fixes (Fuss et al. 2014). We also evaluated RCP 4.5 to represent a future in which significant emissions reductions are achieved.

The following code generates projections for each representative and time period:

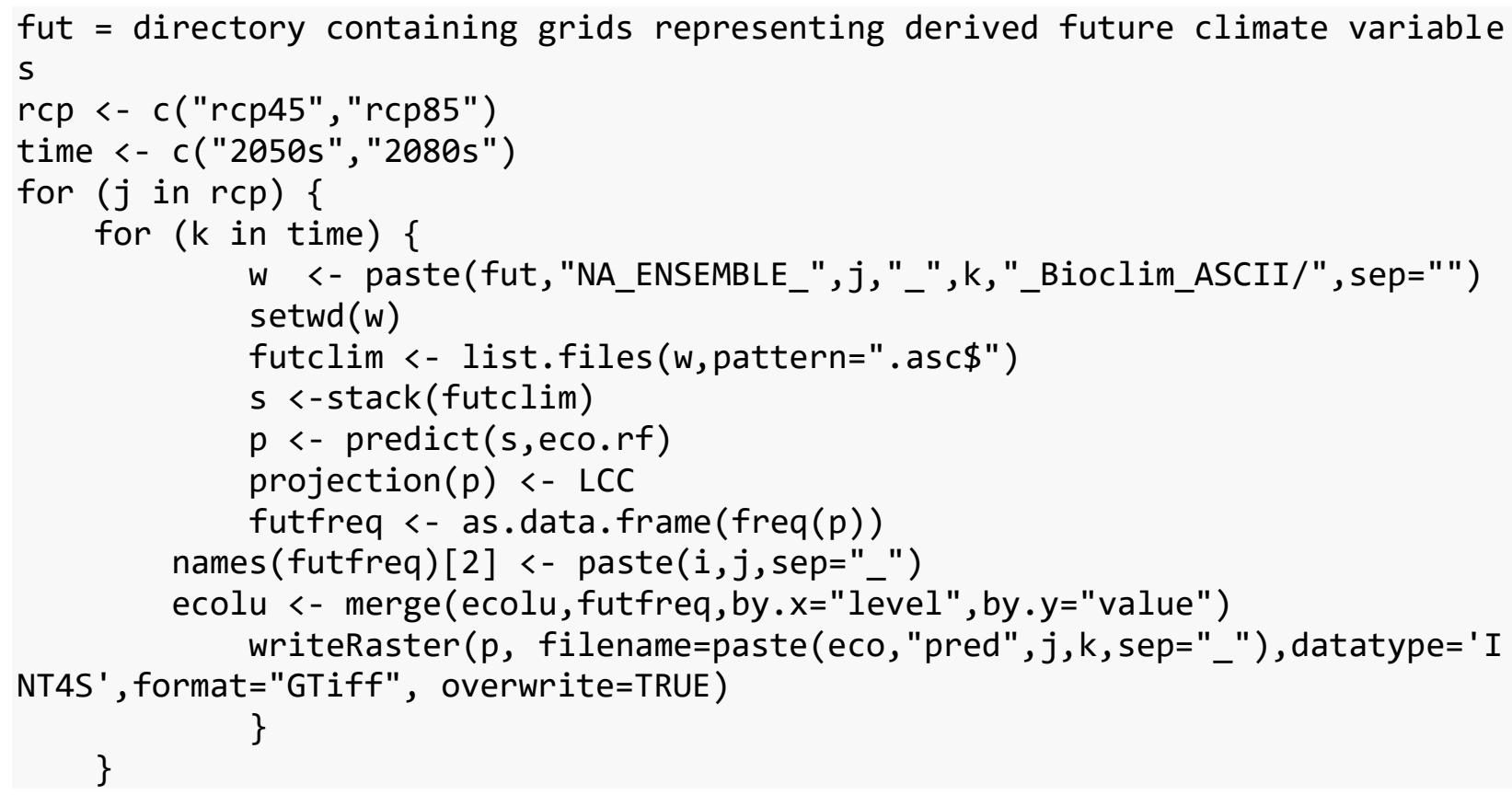


Results for RCP 4.5 and RCP 8.5 are shown in Figures A1.1 and A1.2, respectively:
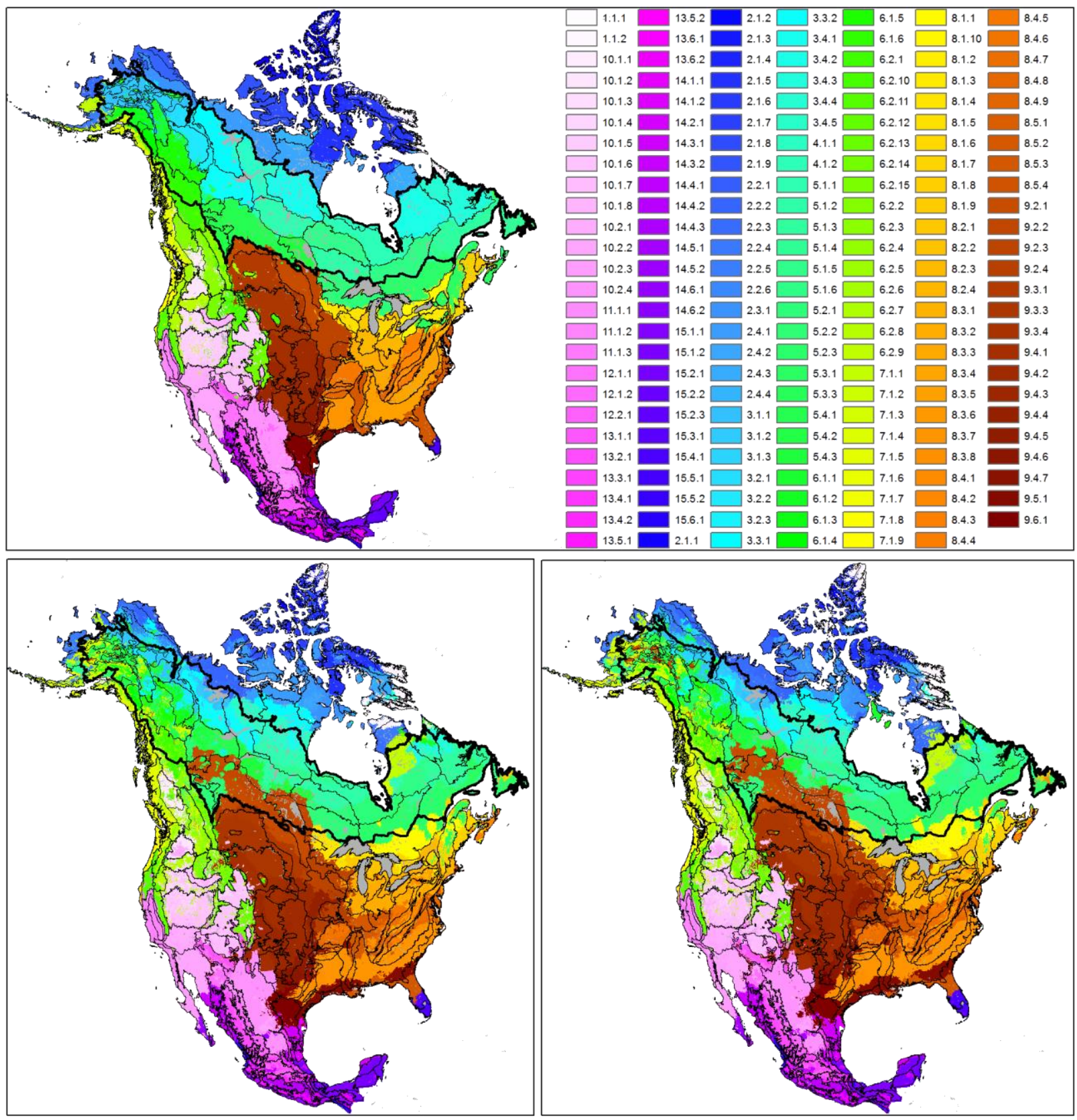

Figure A1.1. Model-predicted (a) baseline, (b) mid-century, and (c) end-of-century changes in North American ecoregions for RCP 4.5. Boreal, hemi-boreal, and western forested regions are shown in green and blue-green shades; arctic ecoregions are in blue shades; prairie/parkland ecoregions are in brown shades; and temperate forest ecoregions are in yellow and orange shades (see Table A1.1 for full list of ecoregions). Boreal ecoregions are also outlined in black. 

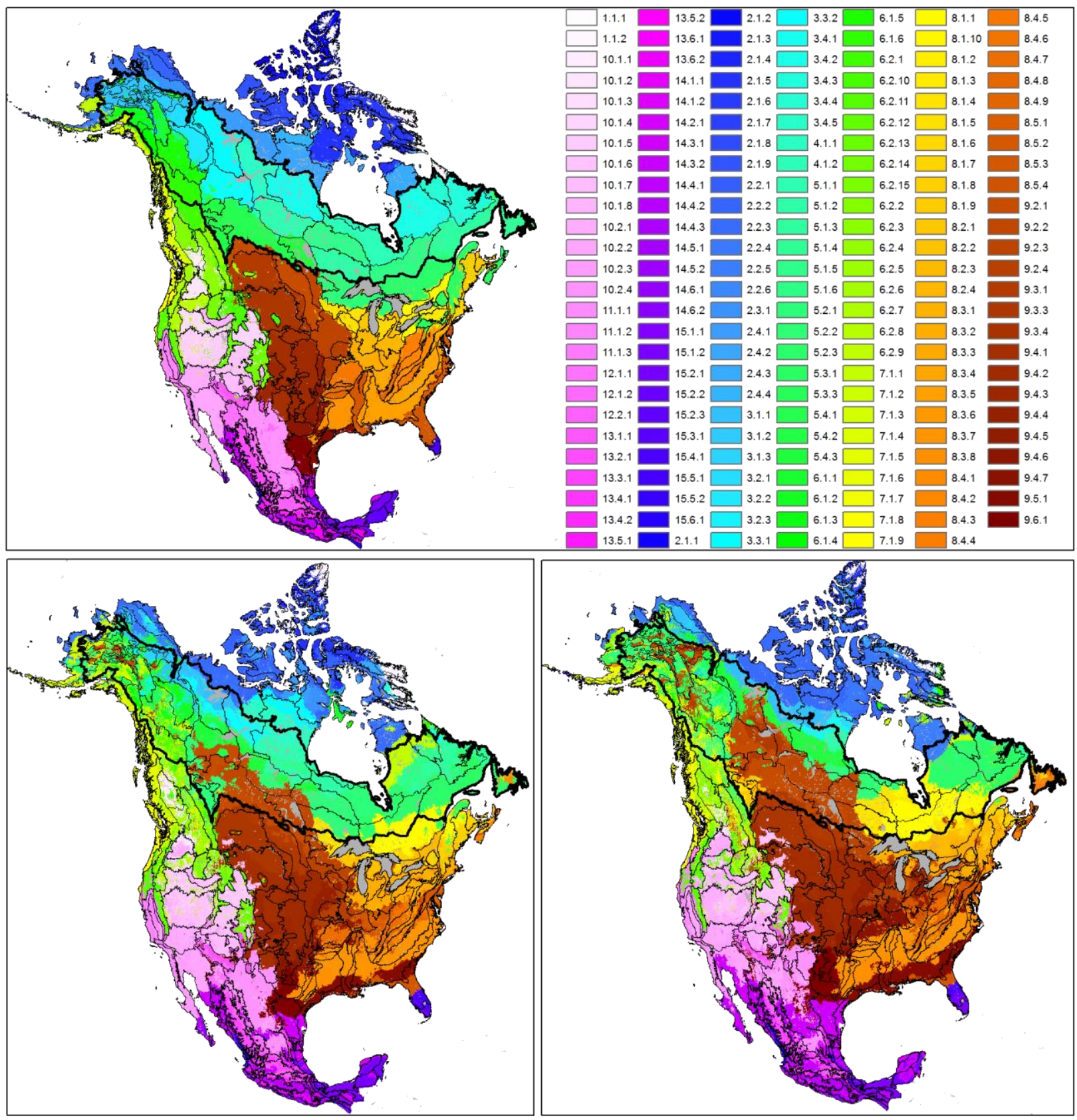

Figure A1.2. Model-predicted (a) baseline, (b) mid-century, and (c) end-of-century changes in North American ecoregions for RCP 8.5. Boreal, hemi-boreal, and western forested regions are shown in green and blue-green shades; arctic ecoregions are in blue shades; prairie/parkland ecoregions are in brown shades; and temperate forest ecoregions are in yellow and orange shades (see Table A1.1 for full list of ecoregions). Boreal ecoregions are also outlined in black. 
Next, we used the following code to calculate the change in area (16 km2 pixels) for each Level III ecoregion (Table A1.2):

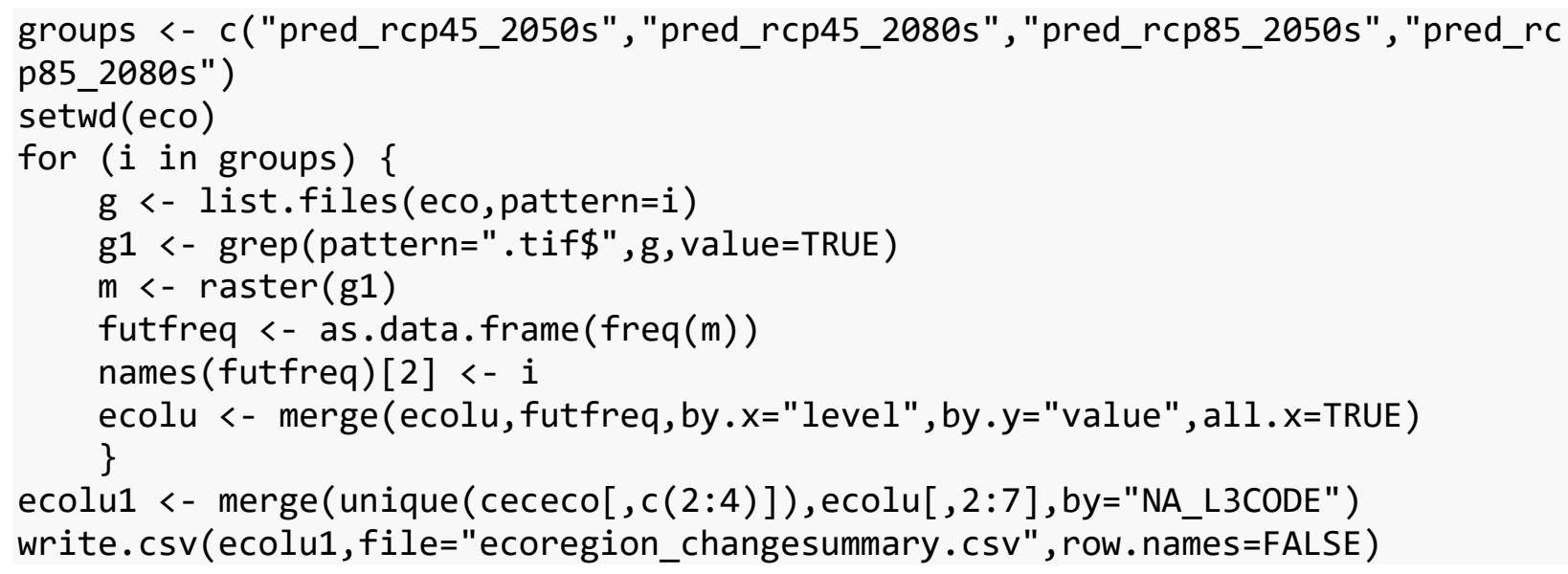

Table A1.2. Model-projected changes by ecoregion (sq km):

\begin{tabular}{|c|c|c|c|c|c|c|}
\hline NA_L3CODE & NA_L3NAME & curr & rcp45_2050s & rcp45_2080s & rcp85_2050s & rcp85_2080s \\
\hline 1.1 .1 & $\begin{array}{l}\text { Ellesmere and Devon } \\
\text { Islands Ice Caps }\end{array}$ & 100,895 & 34,322 & 12,388 & 5,563 & NA \\
\hline 1.1 .2 & $\begin{array}{l}\text { Baffin and Torngat } \\
\text { Mountains }\end{array}$ & 147,147 & 256,752 & 278,424 & 235,507 & 106,740 \\
\hline 10.1 .1 & $\begin{array}{l}\text { Thompson-Okanogan } \\
\text { Plateau }\end{array}$ & 79,481 & 128,181 & 102,991 & 93,853 & 17,523 \\
\hline 10.1 .2 & Columbia Plateau & 87,319 & 128,349 & 130,511 & 133,438 & 92,006 \\
\hline 10.1 .3 & $\begin{array}{l}\text { Northern Basin and } \\
\text { Range }\end{array}$ & 163,503 & 52,087 & 28,000 & 26,510 & 2,500 \\
\hline 10.1 .4 & Wyoming Basin & 142,375 & 20,672 & 10,308 & 8,748 & 317 \\
\hline 10.1.5 & Central Basin and Range & 248,329 & 178,117 & 161,763 & 171,074 & 44,943 \\
\hline 10.1.6 & Colorado Plateaus & 148,135 & 410,063 & 445,829 & 458,570 & 479,993 \\
\hline 10.1.7 & $\begin{array}{l}\text { Arizona/New Mexico } \\
\text { Plateau }\end{array}$ & 170,714 & 215,623 & 216,068 & 215,201 & 137,227 \\
\hline 10.1 .8 & Snake River Plain & 71,248 & 34,098 & 22,125 & 20,400 & 1,620 \\
\hline 10.2 .1 & Mojave Basin and Range & 145,279 & 178,168 & 214,764 & 239,676 & 559,531 \\
\hline 10.2.2 & Sonoran Desert & 249,917 & 313,014 & 308,390 & 333,780 & 477,826 \\
\hline 10.2 .3 & Baja Californian Desert & 125,247 & 108,494 & 133,306 & 143,065 & 130,262 \\
\hline 10.2.4 & Chihuahuan Desert & 560,769 & 634,266 & 615,488 & 614,688 & 512,968 \\
\hline 11.1.1 & $\begin{array}{l}\text { California Coastal Sage, } \\
\text { Chaparral, and Oak } \\
\text { Woodlands }\end{array}$ & 118,844 & 119,971 & 124,429 & 124,621 & 148,146 \\
\hline 11.1.2 & Central California Valley & 59,912 & 55,961 & 47,599 & 41,428 & 920 \\
\hline 11.1.3 & $\begin{array}{l}\text { Southern and Baja } \\
\text { California Pine-Oak } \\
\text { Mountains }\end{array}$ & 40,794 & 52,147 & 49,068 & 48,033 & 34,558 \\
\hline
\end{tabular}




\begin{tabular}{|c|c|c|c|c|c|c|}
\hline NA_L3CODE & NA_L3NAME & curr & rcp45_2050s & rcp45_2080s & rcp85_2050s & rcp85_2080s \\
\hline 12.1 .1 & Madrean Archipelago & 119,798 & 120,764 & 113,420 & 110,430 & 109,247 \\
\hline 12.1.2 & $\begin{array}{l}\text { Piedmonts and Plains } \\
\text { with Grasslands, Xeric } \\
\text { Shrub, and Oak and } \\
\text { Conifer Forests }\end{array}$ & 225,107 & 159,305 & 140,803 & 136,965 & 67,801 \\
\hline 12.2 .1 & $\begin{array}{l}\text { Hills and Interior Plains } \\
\text { with Xeric Shrub and } \\
\text { Mesquite Low Forest }\end{array}$ & 117,722 & 115,409 & 104,551 & 100,841 & 60,874 \\
\hline 13.1 .1 & $\begin{array}{l}\text { Arizona/New Mexico } \\
\text { Mountains }\end{array}$ & 119,795 & 121,932 & 125,652 & 120,830 & 138,375 \\
\hline 13.2 .1 & $\begin{array}{l}\text { Sierra Madre Occidental } \\
\text { with Conifer, Oak, and } \\
\text { Mixed Forests }\end{array}$ & 203,850 & 129,997 & 119,021 & 106,488 & 64,358 \\
\hline 13.3 .1 & $\begin{array}{l}\text { Sierra Madre Oriental } \\
\text { with Conifer, Oak, and } \\
\text { Mixed Forests }\end{array}$ & 99,879 & 112,527 & 125,093 & 125,837 & 102,492 \\
\hline 13.4 .1 & $\begin{array}{l}\text { Interior Plains and } \\
\text { Piedmonts with } \\
\text { Grasslands and Xeric } \\
\text { Shrub }\end{array}$ & 30,155 & 13,136 & 9,148 & 8,526 & 1,347 \\
\hline 13.4 .2 & $\begin{array}{l}\text { Hills and Sierras with } \\
\text { Conifer, Oak, and Mixed } \\
\text { Forests }\end{array}$ & 90,230 & 56,118 & 46,624 & 41,800 & 21,474 \\
\hline 13.5 .1 & $\begin{array}{l}\text { Sierras of Jalisco and } \\
\text { Michoacan with Conifer, } \\
\text { Oak, and Mixed Forests }\end{array}$ & 45,189 & 29,437 & 30,622 & 27,347 & 19,195 \\
\hline 13.5 .2 & $\begin{array}{l}\text { Sierras of Guerrero and } \\
\text { Oaxaca with Conifer, } \\
\text { Oak, and Mixed Forests }\end{array}$ & 93,219 & 56,589 & 51,279 & 46,021 & 21,458 \\
\hline 13.6 .1 & $\begin{array}{l}\text { Central American Sierra } \\
\text { Madre with Conifer, Oak, } \\
\text { and Mixed Forests }\end{array}$ & 24,543 & 10,157 & 8,224 & 8,785 & 2,653 \\
\hline 13.6 .2 & $\begin{array}{l}\text { Chiapas Highlands with } \\
\text { Conifer, Oak, and Mixed } \\
\text { Forest }\end{array}$ & 47,734 & 30,717 & 26,910 & 25,142 & 11,528 \\
\hline 14.1.1 & $\begin{array}{l}\text { Coastal Plain with Low } \\
\text { Tropical Deciduous } \\
\text { Forest }\end{array}$ & 45,021 & 67,157 & 58,930 & 52,306 & 26,294 \\
\hline 14.1 .2 & $\begin{array}{l}\text { Hills and Sierra with Low } \\
\text { Tropical Deciduous } \\
\text { Forest and Oak Forest }\end{array}$ & 32,934 & 27,023 & 22,562 & 21,273 & 9,515 \\
\hline 14.2 .1 & $\begin{array}{l}\text { Northwestern Yucatan } \\
\text { Plain with Low Tropical } \\
\text { Deciduous Forest }\end{array}$ & 21,348 & 31,181 & 43,435 & 42,619 & 120,368 \\
\hline 14.3 .1 & $\begin{array}{l}\text { Sinaloa Coastal Plain with } \\
\text { Low Thorn Tropical } \\
\text { Forest and Wetlands }\end{array}$ & 55,351 & 184,089 & 253,772 & 303,349 & 693,883 \\
\hline 14.3 .2 & $\begin{array}{l}\text { Sinaloa and Sonora Hills } \\
\text { and Canyons with Xeric }\end{array}$ & 116,252 & 161,186 & 188,683 & 190,719 & 386,533 \\
\hline
\end{tabular}




\begin{tabular}{|c|c|c|c|c|c|c|}
\hline NA_L3CODE & NA_L3NAME & curr & rcp45_2050s & rcp45_2080s & rcp85_2050s & rcp85_2080s \\
\hline & $\begin{array}{l}\text { Shrub and Low Tropical } \\
\text { Deciduous Forest }\end{array}$ & & & & & \\
\hline 14.4 .1 & $\begin{array}{l}\text { Balsas Depression with } \\
\text { Low Tropical Deciduous } \\
\text { Forest and Xerophytic } \\
\text { Shrub }\end{array}$ & 94,443 & 142,241 & 155,449 & 167,393 & 217,971 \\
\hline 14.4 .2 & $\begin{array}{l}\text { Chiapas Depression with } \\
\text { Low Deciduous and } \\
\text { Medium Semi-Deciduous } \\
\text { Tropical Forest }\end{array}$ & 27,227 & 13,295 & 11,191 & 10,296 & 9,580 \\
\hline 14.4 .3 & $\begin{array}{l}\text { Valleys and Depressions } \\
\text { with Xeric Shrub and } \\
\text { Low Tropical Deciduous } \\
\text { Forest }\end{array}$ & 27,146 & 38,202 & 36,891 & 37,294 & 35,815 \\
\hline 14.5 .1 & $\begin{array}{l}\text { Tehuantepec Canyon and } \\
\text { Plain with Low Tropical } \\
\text { Deciduous Forest and } \\
\text { Low Thorn Tropical } \\
\text { Forest }\end{array}$ & 19,737 & 41,575 & 43,559 & 41,086 & 52,429 \\
\hline 14.5 .2 & $\begin{array}{l}\text { South Pacific Hills and } \\
\text { Piedmonts with Low } \\
\text { Tropical Deciduous } \\
\text { Forest }\end{array}$ & 66,703 & 85,395 & 99,426 & 102,297 & 119,513 \\
\hline 14.6 .1 & $\begin{array}{l}\text { Los Cabos Plains and } \\
\text { Hills with Low Tropical } \\
\text { Deciduous Forest and } \\
\text { Xeric Shrub }\end{array}$ & 16,353 & 42,909 & 43,769 & 41,573 & 23,672 \\
\hline 14.6 .2 & $\begin{array}{l}\text { La Laguna Mountains } \\
\text { with Oak and Conifer } \\
\text { Forest }\end{array}$ & 2,570 & 1,344 & 1,185 & 1,126 & 501 \\
\hline 15.1.1 & $\begin{array}{l}\text { Gulf of Mexico Coastal } \\
\text { Plain with Wetlands and } \\
\text { High Tropical Rain Forest }\end{array}$ & 92,436 & 160,749 & 153,390 & 154,527 & 136,595 \\
\hline 15.1 .2 & $\begin{array}{l}\text { Hills with Medium and } \\
\text { High Evergreen Tropical } \\
\text { Forest }\end{array}$ & 106,764 & 75,092 & 81,041 & 90,784 & 119,204 \\
\hline 15.2.1 & $\begin{array}{l}\text { Plain with Low and } \\
\text { Medium Deciduous } \\
\text { Tropical Forest }\end{array}$ & 63,136 & 123,240 & 125,750 & 130,375 & 93,831 \\
\hline 15.2 .2 & $\begin{array}{l}\text { Plain with Medium and } \\
\text { High Semi-Evergreen } \\
\text { Tropical Forest }\end{array}$ & 46,630 & 34,045 & 29,748 & 22,123 & 2,786 \\
\hline 15.2 .3 & $\begin{array}{l}\text { Hills with High and } \\
\text { Medium Semi-Evergreen } \\
\text { Tropical Forest }\end{array}$ & 78,883 & 5,709 & 6,137 & 5,979 & 6,417 \\
\hline 15.3 .1 & $\begin{array}{l}\text { Los Tuxtlas Sierra with } \\
\text { High Evergreen Tropical } \\
\text { Forest }\end{array}$ & 10,762 & 2,087 & 1,633 & 1,416 & 13,724 \\
\hline 15.4 .1 & $\begin{array}{l}\text { Southern Florida Coastal } \\
\text { Plain }\end{array}$ & 38,967 & 74,884 & 83,614 & 78,635 & 40,314 \\
\hline
\end{tabular}




\begin{tabular}{|c|c|c|c|c|c|c|}
\hline NA_L3CODE & NA_L3NAME & curr & rcp45_2050s & rcp45_2080s & rcp85_2050s & rcp85_2080s \\
\hline 15.5 .1 & $\begin{array}{l}\text { Nayarit and Sinaloa Plain } \\
\text { with Low Thorn Tropical } \\
\text { Forest }\end{array}$ & 9,738 & 2,650 & 1,532 & 1,425 & 1,651 \\
\hline 15.5 .2 & $\begin{array}{l}\text { Jalisco and Nayarit Hills } \\
\text { and Plains with Medium } \\
\text { Semi-Evergreen Tropical } \\
\text { Forest }\end{array}$ & 20,266 & 42,203 & 49,771 & 52,308 & 75,866 \\
\hline 15.6 .1 & $\begin{array}{l}\text { Coastal Plain and Hills } \\
\text { with High and Medium- } \\
\text { High Evergreen Tropical } \\
\text { Forest and Wetlands }\end{array}$ & 20,201 & 25,035 & 18,554 & 17,797 & 7,691 \\
\hline 2.1 .1 & Sverdrup Islands Lowland & 62,199 & 75 & NA & NA & NA \\
\hline 2.1 .2 & $\begin{array}{l}\text { Ellesmere Mountains and } \\
\text { Eureka Hills }\end{array}$ & 152,595 & 20,260 & 8,298 & 4,690 & NA \\
\hline 2.1 .3 & Parry Islands Plateau & 84,303 & 6,226 & 581 & 303 & NA \\
\hline 2.1 .4 & $\begin{array}{l}\text { Lancaster and Borden } \\
\text { Peninsula Plateaus }\end{array}$ & 153,401 & 100,458 & 57,518 & 52,380 & 2 \\
\hline 2.1 .5 & Foxe Uplands & 359,792 & 172,936 & 212,147 & 159,876 & 76,162 \\
\hline 2.1 .6 & Baffin Uplands & 148,664 & 39,067 & 32,090 & 28,237 & 22,447 \\
\hline 2.1 .7 & $\begin{array}{l}\text { Gulf of Boothia and Foxe } \\
\text { Basin Plains }\end{array}$ & 147,691 & 94,997 & 44,196 & 30,062 & 4,356 \\
\hline 2.1 .8 & Victoria Island Lowlands & 173,942 & 17,900 & 1,278 & 105 & NA \\
\hline 2.1 .9 & $\begin{array}{l}\text { Banks Island and } \\
\text { Amundsen Gulf Lowlands }\end{array}$ & 160,336 & 239,188 & 224,215 & 194,489 & 15,065 \\
\hline 2.2 .1 & Arctic Coastal Plain & 58,756 & 95 & 2,266 & 5,255 & 22,959 \\
\hline 2.2 .2 & Arctic Foothills & 123,434 & 235,933 & 305,118 & 459,436 & 119,091 \\
\hline 2.2 .3 & Subarctic Coastal Plains & 100,808 & 229,447 & 323,128 & 388,110 & $1,281,925$ \\
\hline 2.2 .4 & Seward Peninsula & 59,337 & 156,920 & 256,979 & 281,469 & 286,106 \\
\hline 2.2 .5 & $\begin{array}{l}\text { Bristol Bay-Nushagak } \\
\text { Lowlands }\end{array}$ & 63,649 & 106,118 & 103,595 & 106,972 & 389,553 \\
\hline 2.2 .6 & Aleution Islands & 12,993 & 4,767 & 2,467 & 2,058 & 1,132 \\
\hline 2.3 .1 & $\begin{array}{l}\text { Brooks Range/Richardson } \\
\text { Mountains }\end{array}$ & 140,490 & 131,925 & 94,546 & 71,108 & NA \\
\hline 2.4 .1 & Amundsen Plains & 285,721 & 491,512 & 345,481 & 217,998 & 44,812 \\
\hline 2.4 .2 & Aberdeen Plains & 280,025 & 34,118 & 100 & NA & NA \\
\hline 2.4 .3 & $\begin{array}{l}\text { Central Ungava Peninsula } \\
\text { and Ottawa and Belcher } \\
\text { Islands }\end{array}$ & 168,795 & 136,014 & 90,049 & 83,728 & 57,559 \\
\hline 2.4 .4 & $\begin{array}{l}\text { Queen Maud Gulf and } \\
\text { Chantrey Inlet Lowlands }\end{array}$ & 112,616 & NA & NA & NA & NA \\
\hline 3.1 .1 & $\begin{array}{l}\text { Interior Forested } \\
\text { Lowlands and Uplands }\end{array}$ & 154,744 & 214,494 & 244,642 & 302,972 & 397,504 \\
\hline 3.1 .2 & Interior Bottomlands & 147,095 & 104,970 & 89,188 & 60,760 & 24,020 \\
\hline 3.1 .3 & Yukon Flats & 43,564 & 57,030 & 38,887 & 47,545 & 20,218 \\
\hline 3.2 .1 & Ogilvie Mountains & 78,032 & 84,458 & 80,561 & 67,101 & 40,699 \\
\hline 3.2 .2 & Mackenzie and Selwyn & 149,527 & 32,955 & 14,823 & 6,602 & NA \\
\hline
\end{tabular}




\begin{tabular}{|c|c|c|c|c|c|c|}
\hline NA_L3CODE & NA_L3NAME & curr & rcp45_2050s & rcp45_2080s & rcp85_2050s & rcp85_2080s \\
\hline & Mountains & & & & & \\
\hline 3.2 .3 & $\begin{array}{l}\text { Peel River and Nahanni } \\
\text { Plateaus }\end{array}$ & 101,694 & 26,898 & 15,237 & 8,576 & NA \\
\hline 3.3 .1 & Great Bear Plains & 294,795 & 199,901 & 184,944 & 169,822 & NA \\
\hline 3.3 .2 & $\begin{array}{l}\text { Hay and Slave River } \\
\text { Lowlands }\end{array}$ & 273,770 & 329,298 & 260,311 & 228,498 & 88,246 \\
\hline 3.4 .1 & $\begin{array}{l}\text { Kazan River and Selwyn } \\
\text { Lake Uplands }\end{array}$ & 344,325 & 49,210 & 26,918 & 6,432 & NA \\
\hline 3.4 .2 & $\begin{array}{l}\text { La Grande Hills and New } \\
\text { Quebec Central Plateau }\end{array}$ & 367,682 & 55,553 & 3,009 & 482 & NA \\
\hline 3.4 .3 & Smallwood Uplands & 260,456 & 72,043 & 45,379 & 31,847 & 8,018 \\
\hline 3.4 .4 & $\begin{array}{l}\text { Ungava Bay Basin and } \\
\text { George Plateau }\end{array}$ & 124,658 & 16,561 & 15,184 & 14,273 & 175 \\
\hline 3.4 .5 & $\begin{array}{l}\text { Coppermine River and } \\
\text { Tazin Lake Uplands }\end{array}$ & 247,484 & 278,724 & 261,461 & 289,089 & 3,376 \\
\hline 4.1 .1 & $\begin{array}{l}\text { Coastal Hudson Bay } \\
\text { Lowland }\end{array}$ & 79,752 & 39,794 & 39,597 & 27,964 & NA \\
\hline 4.1 .2 & $\begin{array}{l}\text { Hudson Bay and James } \\
\text { Bay Lowlands }\end{array}$ & 277,767 & 56,692 & 24,743 & 18,601 & 4,711 \\
\hline 5.1 .1 & $\begin{array}{l}\text { Athabasca Plain and } \\
\text { Churchill River Upland }\end{array}$ & 261,634 & 180,539 & 172,825 & 169,140 & 61,254 \\
\hline 5.1 .2 & $\begin{array}{l}\text { Lake Nipigon and Lac } \\
\text { Seul Upland }\end{array}$ & 217,842 & 383,191 & 334,585 & 292,786 & 77,691 \\
\hline 5.1 .3 & $\begin{array}{l}\text { Central Laurentians and } \\
\text { Mecatina Plateau }\end{array}$ & 302,052 & 319,010 & 262,655 & 245,088 & 61,726 \\
\hline 5.1 .4 & Newfoundland Island & 125,291 & 159,633 & 150,097 & 145,165 & 141,949 \\
\hline 5.1 .5 & $\begin{array}{l}\text { Hayes River Upland and } \\
\text { Big Trout Lake }\end{array}$ & 264,910 & 99,563 & 68,160 & 60,244 & 1,195 \\
\hline 5.1 .6 & $\begin{array}{l}\text { Abitibi Plains and Riviere } \\
\text { Rupert Plateau }\end{array}$ & 287,990 & 145,527 & 142,434 & 111,390 & 15,384 \\
\hline 5.2 .1 & $\begin{array}{l}\text { Northern Lakes and } \\
\text { Forests }\end{array}$ & 297,661 & 550,438 & 693,642 & 770,212 & 567,791 \\
\hline 5.2 .2 & $\begin{array}{l}\text { Northern Minnesota } \\
\text { Wetlands }\end{array}$ & 39,487 & NA & NA & NA & NA \\
\hline 5.2 .3 & $\begin{array}{l}\text { Algonquin/Southern } \\
\text { Laurentians }\end{array}$ & 350,698 & 443,628 & 423,668 & 436,081 & 460,129 \\
\hline 5.3 .1 & $\begin{array}{l}\text { Northern Appalachian and } \\
\text { Atlantic Maritime } \\
\text { Highlands }\end{array}$ & 213,235 & 297,005 & 324,996 & 338,882 & 484,216 \\
\hline 5.3 .3 & $\begin{array}{l}\text { North Central } \\
\text { Appalachians }\end{array}$ & 40,906 & 5,581 & 6,484 & 7,114 & 15,510 \\
\hline 5.4 .1 & $\begin{array}{l}\text { Mid-Boreal Uplands and } \\
\text { Peace-Wabaska Lowlands }\end{array}$ & 384,861 & 384,235 & 311,499 & 240,506 & 112,622 \\
\hline 5.4 .2 & $\begin{array}{l}\text { Clear Hills and Western } \\
\text { Alberta Upland }\end{array}$ & 147,911 & 76,236 & 63,250 & 52,958 & 8,624 \\
\hline 5.4 .3 & $\begin{array}{l}\text { Mid-Boreal Lowland and } \\
\text { Interlake Plain }\end{array}$ & 137,275 & 232,935 & 277,233 & 324,472 & 401,337 \\
\hline
\end{tabular}




\begin{tabular}{|c|c|c|c|c|c|c|}
\hline NA_L3CODE & NA_L3NAME & curr & rcp45_2050s & rcp45_2080s & rcp85_2050s & rcp85_2080s \\
\hline 6.1 .1 & $\begin{array}{l}\text { Interior Highlands and } \\
\text { Klondike Plateau }\end{array}$ & 125,183 & 86,212 & 115,739 & 128,553 & 19,129 \\
\hline 6.1 .2 & Alaska Range & 101,281 & 86,438 & 91,774 & 95,471 & 35,952 \\
\hline 6.1 .3 & Copper Plateau & 25,317 & 7,840 & 1,044 & 376 & 21 \\
\hline 6.1 .4 & $\begin{array}{l}\text { Wrangell and St. Elias } \\
\text { Mountains }\end{array}$ & 58,813 & 35,893 & 27,452 & 23,311 & 14,394 \\
\hline 6.1 .5 & Watson Highlands & 215,821 & 109,456 & 57,769 & 43,653 & 6,952 \\
\hline 6.1 .6 & $\begin{array}{l}\text { Yukon-Stikine } \\
\text { Highlands/Boreal } \\
\text { Mountains and Plateaus }\end{array}$ & 162,769 & 50,965 & 43,275 & 34,939 & 23,134 \\
\hline 6.2 .1 & $\begin{array}{l}\text { Skeena-Omineca-Central } \\
\text { Canadian Rocky } \\
\text { Mountains }\end{array}$ & 146,470 & 160,853 & 135,239 & 120,210 & 50,879 \\
\hline 6.2 .10 & Middle Rockies & 161,078 & 55,926 & 45,646 & 40,694 & 18,262 \\
\hline 6.2 .11 & Klamath Mountains & 59,290 & 100,615 & 113,637 & 116,533 & 190,016 \\
\hline 6.2 .12 & Sierra Nevada & 56,436 & 44,004 & 41,467 & 40,535 & 22,943 \\
\hline 6.2 .13 & $\begin{array}{l}\text { Wasatch and Uinta } \\
\text { Mountains }\end{array}$ & 95,639 & 85,060 & 84,545 & 82,247 & 40,683 \\
\hline 6.2 .14 & Southern Rockies & 146,075 & 79,895 & 64,838 & 51,395 & 25,539 \\
\hline 6.2 .15 & Idaho Batholith & 74,737 & 76,608 & 70,690 & 73,617 & 53,969 \\
\hline 6.2 .2 & $\begin{array}{l}\text { Chilcotin Ranges and } \\
\text { Fraser Plateau }\end{array}$ & 113,621 & 7,374 & 2,090 & 1,782 & 122 \\
\hline 6.2 .3 & $\begin{array}{l}\text { Columbia } \\
\text { Mountains/Northern } \\
\text { Rockies }\end{array}$ & 161,058 & 252,240 & 264,915 & 271,050 & 274,785 \\
\hline 6.2 .4 & Canadian Rockies & 106,010 & 53,214 & 33,347 & 23,701 & 3,133 \\
\hline 6.2 .5 & North Cascades & 41,160 & 35,151 & 31,590 & 30,225 & 19,980 \\
\hline 6.2 .6 & Cypress Upland & 22,463 & 925 & 2,326 & 3,179 & 3,527 \\
\hline 6.2 .7 & Cascades & 48,106 & 30,917 & 32,153 & 30,980 & 24,273 \\
\hline 6.2 .8 & $\begin{array}{l}\text { Eastern Cascades Slopes } \\
\text { and Foothills }\end{array}$ & 76,924 & 50,858 & 39,265 & 37,516 & 10,082 \\
\hline 6.2 .9 & Blue Mountains & 81,264 & 122,265 & 114,078 & 110,356 & 113,839 \\
\hline 7.1 .1 & $\begin{array}{l}\text { Ahklun and Kilbuck } \\
\text { Mountains }\end{array}$ & 62,628 & 210,151 & 224,034 & 200,959 & 32,945 \\
\hline 7.1 .2 & $\begin{array}{l}\text { Alaska Peninsula } \\
\text { Mountains }\end{array}$ & 54,947 & 28,924 & 27,208 & 26,629 & 22,337 \\
\hline 7.1 .3 & Cook Inlet & 31,714 & 258,308 & 325,196 & 360,731 & 204,427 \\
\hline 7.1 .4 & Pacific Coastal Mountains & 109,324 & 110,053 & 113,038 & 112,518 & 87,051 \\
\hline 7.1 .5 & $\begin{array}{l}\text { Coastal Western } \\
\text { Hemlock-Sitka Spruce } \\
\text { Forests }\end{array}$ & 96,025 & 167,783 & 176,032 & 178,428 & 163,666 \\
\hline 7.1 .6 & Pacific and Nass Ranges & 99,230 & 133,991 & 150,169 & 153,362 & 154,938 \\
\hline 7.1 .7 & $\begin{array}{l}\text { Strait of Georgia/Puget } \\
\text { Lowland }\end{array}$ & 48,048 & 37,542 & 41,816 & 44,456 & 80,267 \\
\hline 7.1.8 & Coast Range & 57,502 & 111,722 & 124,460 & 125,210 & 146,726 \\
\hline
\end{tabular}




\begin{tabular}{|c|c|c|c|c|c|c|}
\hline NA_L3CODE & NA_L3NAME & curr & rcp45_2050s & rcp45_2080s & rcp85_2050s & rcp85_2080s \\
\hline 7.1 .9 & Willamette Valley & 19,425 & 4,945 & 3,615 & 3,925 & 12,446 \\
\hline 8.1 .1 & $\begin{array}{l}\text { Eastern Great Lakes } \\
\text { Lowlands }\end{array}$ & 185,396 & 399,806 & 511,228 & 563,219 & 801,293 \\
\hline 8.1 .10 & Erie Drift Plain & 54,959 & 3,115 & 593 & 373 & 182 \\
\hline 8.1 .2 & Lake Erie Lowland & 71,512 & 71,944 & 50,905 & 53,404 & 21,297 \\
\hline 8.1 .3 & $\begin{array}{l}\text { Northern Allegheny } \\
\text { Plateau }\end{array}$ & 56,906 & 1,487 & 534 & 560 & 23,971 \\
\hline 8.1 .4 & $\begin{array}{l}\text { North Central Hardwood } \\
\text { Forests }\end{array}$ & 107,373 & 103,169 & 108,931 & 101,597 & 237,007 \\
\hline 8.1 .5 & Driftless Area & 56,904 & 27,122 & 6,541 & 9,722 & 56,230 \\
\hline 8.1 .6 & $\begin{array}{l}\text { Southern } \\
\text { Michigan/Northern } \\
\text { Indiana Drift Plains }\end{array}$ & 81,430 & 23,829 & 17,145 & 13,253 & 417 \\
\hline 8.1 .7 & $\begin{array}{l}\text { Northeastern Coastal } \\
\text { Zone }\end{array}$ & 61,604 & 230,818 & 254,436 & 245,976 & 200,520 \\
\hline 8.1 .8 & Acadian Plains and Hills & 111,308 & 40,773 & 46,764 & 37,862 & 28,274 \\
\hline 8.1 .9 & Maritime Lowlands & 46,701 & 13,691 & 12,593 & 8,969 & 8,838 \\
\hline 8.2 .1 & $\begin{array}{l}\text { Southeastern Wisconsin } \\
\text { Till Plains }\end{array}$ & 41,043 & 42,756 & 43,861 & 32,257 & 90,658 \\
\hline 8.2 .2 & Huron/Erie Lake Plains & 54,469 & 85,966 & 67,329 & 61,276 & 28,067 \\
\hline 8.2 .3 & Central Corn Belt Plains & 92,678 & 73,997 & 100,504 & 140,394 & 250,957 \\
\hline 8.2 .4 & Eastern Corn Belt Plains & 87,010 & 39,615 & 33,682 & 36,241 & 8,857 \\
\hline 8.3 .1 & Northern Piedmont & 42,573 & 170,005 & 167,343 & 153,662 & 53,715 \\
\hline 8.3 .2 & $\begin{array}{l}\text { Interior River Valleys and } \\
\text { Hills }\end{array}$ & 131,437 & 373,661 & 383,500 & 408,178 & 433,738 \\
\hline 8.3 .3 & Interior Plateau & 145,391 & 60,581 & 57,552 & 55,578 & 50,507 \\
\hline 8.3 .4 & Piedmont & 199,405 & 24,230 & 20,990 & 15,243 & 2,166 \\
\hline 8.3 .5 & Southeastern Plains & 304,687 & 9,091 & 6,755 & 7,501 & 3,549 \\
\hline 8.3 .6 & $\begin{array}{l}\text { Mississippi Valley Loess } \\
\text { Plains }\end{array}$ & 85,927 & 13,701 & 11,629 & 9,952 & 22,612 \\
\hline 8.3 .7 & South Central Plains & 178,978 & 701,415 & 692,767 & 704,770 & 611,455 \\
\hline 8.3 .8 & East Central Texas Plains & 62,055 & 166,974 & 215,681 & 249,240 & 433,078 \\
\hline 8.4 .1 & Ridge and Valley & 85,618 & 29,098 & 16,038 & 10,560 & 2,334 \\
\hline 8.4 .2 & Central Appalachians & 89,927 & 51,069 & 40,889 & 44,792 & 66,604 \\
\hline 8.4 .3 & $\begin{array}{l}\text { Western Allegheny } \\
\text { Plateau }\end{array}$ & 83,575 & 8,479 & 4,804 & 3,360 & 15 \\
\hline 8.4 .4 & Blue Ridge & 51,004 & 33,856 & 35,301 & 35,072 & 66,437 \\
\hline 8.4 .5 & Ozark Highlands & 109,761 & 76,718 & 42,713 & 26,546 & 1,981 \\
\hline 8.4 .6 & Boston Mountains & 24,203 & 60,902 & 63,537 & 39,483 & 5,440 \\
\hline 8.4 .7 & Arkansas Valley & 38,145 & 140,421 & 168,122 & 184,531 & 89,087 \\
\hline 8.4 .8 & Ouachita Mountains & 30,471 & 87,982 & 86,472 & 65,818 & 32,104 \\
\hline 8.4 .9 & $\begin{array}{l}\text { Southwestern } \\
\text { Appalachians }\end{array}$ & 61,141 & 14,531 & 10,304 & 8,422 & 5,821 \\
\hline 8.5 .1 & Middle Atlantic Coastal & 114,545 & 16,124 & 25,858 & 17,272 & 22,159 \\
\hline
\end{tabular}




\begin{tabular}{|c|c|c|c|c|c|c|}
\hline NA_L3CODE & NA_L3NAME & curr & rcp45_2050s & rcp45_2080s & rcp85_2050s & rcp85_2080s \\
\hline & Plain & & & & & \\
\hline 8.5 .2 & Mississippi Alluvial Plain & 149,150 & 337,261 & 334,998 & 319,597 & 370,833 \\
\hline 8.5 .3 & Southern Coastal Plain & 186,085 & 95,570 & 86,825 & 80,677 & 60,148 \\
\hline 8.5 .4 & $\begin{array}{l}\text { Atlantic Coastal Pine } \\
\text { Barrens }\end{array}$ & 20,263 & 22,794 & 35,426 & 36,084 & 99,628 \\
\hline 9.2 .1 & $\begin{array}{l}\text { Aspen Parkland/Northern } \\
\text { Glaciated Plains }\end{array}$ & 318,674 & 466,186 & 519,631 & 546,675 & 837,779 \\
\hline 9.2 .2 & $\begin{array}{l}\text { Lake Manitoba and Lake } \\
\text { Agassiz Plain }\end{array}$ & 106,437 & 403,991 & 440,897 & 460,192 & 452,954 \\
\hline 9.2 .3 & Western Corn Belt Plains & 218,212 & 262,681 & 224,934 & 223,667 & 209,025 \\
\hline 9.2 .4 & Central Irregular Plains & 134,204 & 204,341 & 223,959 & 238,121 & 321,836 \\
\hline 9.3 .1 & $\begin{array}{l}\text { Northwestern Glaciated } \\
\text { Plains }\end{array}$ & 366,518 & 251,564 & 231,664 & 245,870 & 563,860 \\
\hline 9.3 .3 & Northwestern Great Plains & 368,298 & 448,245 & 460,729 & 457,994 & 390,148 \\
\hline 9.3 .4 & Nebraska Sand Hills & 82,506 & 46 & 27 & 60 & 4,846 \\
\hline 9.4 .1 & High Plains & 292,621 & 434,924 & 488,715 & 495,241 & 467,915 \\
\hline 9.4 .2 & Central Great Plains & 272,514 & 356,382 & 397,340 & 404,906 & 632,890 \\
\hline 9.4 .3 & Southwestern Tablelands & 239,595 & 364,196 & 362,126 & 335,141 & 293,115 \\
\hline 9.4 .4 & Flint Hills & 48,028 & 113,851 & 146,532 & 151,212 & 154,204 \\
\hline 9.4 .5 & Cross Timbers & 108,973 & 104,547 & 117,198 & 141,406 & 379,103 \\
\hline 9.4 .6 & Edwards Plateau & 111,195 & 113,999 & 97,552 & 80,404 & 27,236 \\
\hline 9.4 .7 & Texas Blackland Prairies & 65,484 & 90,892 & 78,487 & 87,808 & 204,468 \\
\hline 9.5 .1 & $\begin{array}{l}\text { Western Gulf Coastal } \\
\text { Plain }\end{array}$ & 115,252 & 270,442 & 323,841 & 345,851 & 502,966 \\
\hline 9.6 .1 & $\begin{array}{l}\text { Southern Texas } \\
\text { Plains/Interior Plains and } \\
\text { Hills with Xerophytic } \\
\text { Shrub and Oak Forest }\end{array}$ & 192,562 & 253,019 & 291,794 & 296,432 & 391,367 \\
\hline
\end{tabular}

We also specifically summarized changes for boreal ecoregions $(4.1,5.4,5.1,3.4,3.3,3.2,3.1$, and 6.1) (Table A1.3):

Table A1.3. Model-projected changes by boreal ecoregion ( $\mathrm{sq} \mathrm{km})$ :

\begin{tabular}{llrrrrr} 
NA_L3CODE & NA_L3NAME & curr & rcp45_2050s & rcp45_2080s & rcp85_2050s & rcp85_2080s \\
\hline 3.1 .1 & Interior Forested & 154,744 & 214,494 & 244,642 & 302,972 & 397,504 \\
& Lowlands and Uplands & & & & & \\
3.1 .2 & Interior Bottomlands & 147,095 & 104,970 & 89,188 & 60,760 & 24,020 \\
3.1 .3 & Yukon Flats & 43,564 & 57,030 & 38,887 & 47,545 & 20,218 \\
3.2 .1 & Ogilvie Mountains & 78,032 & 84,458 & 80,561 & 67,101 & 40,699 \\
3.2 .2 & Mackenzie and Selwyn & 149,527 & 32,955 & 14,823 & 6,602 & NA \\
& Mountains & & & & & NA
\end{tabular}


Plateaus

\begin{tabular}{|c|c|c|c|c|c|c|}
\hline 3.3 .1 & Great Bear Plains & 294,795 & 199,901 & 184,944 & 169,822 & NA \\
\hline 3.3 .2 & $\begin{array}{l}\text { Hay and Slave River } \\
\text { Lowlands }\end{array}$ & 273,770 & 329,298 & 260,311 & 228,498 & 88,246 \\
\hline 3.4 .1 & $\begin{array}{l}\text { Kazan River and Selwyn } \\
\text { Lake Uplands }\end{array}$ & 344,325 & 49,210 & 26,918 & 6,432 & NA \\
\hline 3.4 .2 & $\begin{array}{l}\text { La Grande Hills and New } \\
\text { Quebec Central Plateau }\end{array}$ & 367,682 & 55,553 & 3,009 & 482 & NA \\
\hline 3.4 .3 & Smallwood Uplands & 260,456 & 72,043 & 45,379 & 31,847 & 8,018 \\
\hline 3.4 .4 & $\begin{array}{l}\text { Ungava Bay Basin and } \\
\text { George Plateau }\end{array}$ & 124,658 & 16,561 & 15,184 & 14,273 & 175 \\
\hline 3.4 .5 & $\begin{array}{l}\text { Coppermine River and } \\
\text { Tazin Lake Uplands }\end{array}$ & 247,484 & 278,724 & 261,461 & 289,089 & 3,376 \\
\hline 4.1 .1 & $\begin{array}{l}\text { Coastal Hudson Bay } \\
\text { Lowland }\end{array}$ & 79,752 & 39,794 & 39,597 & 27,964 & NA \\
\hline 4.1 .2 & $\begin{array}{l}\text { Hudson Bay and James } \\
\text { Bay Lowlands }\end{array}$ & 277,767 & 56,692 & 24,743 & 18,601 & 4,711 \\
\hline 5.1 .1 & $\begin{array}{l}\text { Athabasca Plain and } \\
\text { Churchill River Upland }\end{array}$ & 261,634 & 180,539 & 172,825 & 169,140 & 61,254 \\
\hline 5.1 .2 & $\begin{array}{l}\text { Lake Nipigon and Lac } \\
\text { Seul Upland }\end{array}$ & 217,842 & 383,191 & 334,585 & 292,786 & 77,691 \\
\hline 5.1 .3 & $\begin{array}{l}\text { Central Laurentians and } \\
\text { Mecatina Plateau }\end{array}$ & 302,052 & 319,010 & 262,655 & 245,088 & 61,726 \\
\hline 5.1 .4 & Newfoundland Island & 125,291 & 159,633 & 150,097 & 145,165 & 141,949 \\
\hline 5.1 .5 & $\begin{array}{l}\text { Hayes River Upland and } \\
\text { Big Trout Lake }\end{array}$ & 264,910 & 99,563 & 68,160 & 60,244 & 1,195 \\
\hline 5.1 .6 & $\begin{array}{l}\text { Abitibi Plains and Riviere } \\
\text { Rupert Plateau }\end{array}$ & 287,990 & 145,527 & 142,434 & 111,390 & 15,384 \\
\hline 5.4 .1 & $\begin{array}{l}\text { Mid-Boreal Uplands and } \\
\text { Peace-Wabaska Lowlands }\end{array}$ & 384,861 & 384,235 & 311,499 & 240,506 & 112,622 \\
\hline 5.4 .2 & $\begin{array}{l}\text { Clear Hills and Western } \\
\text { Alberta Upland }\end{array}$ & 147,911 & 76,236 & 63,250 & 52,958 & 8,624 \\
\hline 5.4 .3 & $\begin{array}{l}\text { Mid-Boreal Lowland and } \\
\text { Interlake Plain }\end{array}$ & 137,275 & 232,935 & 277,233 & 324,472 & 401,337 \\
\hline 6.1 .1 & $\begin{array}{l}\text { Interior Highlands and } \\
\text { Klondike Plateau }\end{array}$ & 125,183 & 86,212 & 115,739 & 128,553 & 19,129 \\
\hline 6.1 .2 & Alaska Range & 101,281 & 86,438 & 91,774 & 95,471 & 35,952 \\
\hline 6.1 .3 & Copper Plateau & 25,317 & 7,840 & 1,044 & 376 & 21 \\
\hline 6.1 .4 & $\begin{array}{l}\text { Wrangell and St. Elias } \\
\text { Mountains }\end{array}$ & 58,813 & 35,893 & 27,452 & 23,311 & 14,394 \\
\hline 6.1 .5 & Watson Highlands & 215,821 & 109,456 & 57,769 & 43,653 & 6,952 \\
\hline 6.1 .6 & $\begin{array}{l}\text { Yukon-Stikine } \\
\text { Highlands/Boreal } \\
\text { Mountains and Plateaus }\end{array}$ & 162,769 & 50,965 & 43,275 & 34,939 & 23,134 \\
\hline
\end{tabular}

This translates into 14\% and 42\% losses of boreal climate space by 2041-2070 and 2071-2100, respectively, based on RCP 8.5; or 9\% and $13 \%$ losses based on RCP 4.5 


\section{References}

Breiman, L. 2001. Random Forests. Machine Learning 45:5-32.

Commission for Environmental Cooperation. 1997. Ecological Regions of North America: Toward a Common Perspective, Montreal, Canada.

Fuss, S., J. G. Canadell, G. P. Peters, M. Tavoni, R. M. Andrew, P. Ciais, R. B. Jackson, C. D. Jones, F. Kraxner, N. Nakicenovic, C. Le Quere, M. R. Raupach, A. Sharifi, P. Smith, and Y. Yamagata. 2014. Betting on negative emissions. Nature Climate Change 4:850-853.

Hamann, A., T. Wang, D. L. Spittlehouse, and T. Q. Murdock. 2013. A comprehensive, highresolution database of historical and projected climate surfaces for western North America. Bulletin of the American Meteorological Society 94:1307-1309.

Rehfeldt, G. E., N. L. Crookston, C. Sáenz-Romero, and E. M. Campbell. 2012. North American vegetation model for land-use planning in a changing climate: a solution to large classification problems. Ecological Applications 22:119-141.

Taylor, K. E., R. J. Stouffer, and G. A. Meehl. 2012. An Overview of CMIP5 and the Experiment Design. Bulletin of the American Meteorological Society 93:485-498.

Wang, T., A. Hamann, D. Spittlehouse, and C. Carroll. 2016. Locally Downscaled and Spatially Customizable Climate Data for Historical and Future Periods for North America. PLoS ONE 11:e0156720. 
Appendix 2. Components of climate-change vulnerability for 54 boreal-breeding passerine species. Long-term trend values are based on Canada-wide BBS \% change for 2002-2015 (Environment and Climate Change Canada 2017). For all species but Bicknell's Thrush (BITH), projected future change values are based on mid-century (2041-2070) mean potential density estimates for the North American boreal region based on the A2 emission scenario and four global climate models (GCM) (Stralberg et al. 2015b). For BITH, the future projection is based on a model from Lambert and McFarland (2004) applied to RCP 4.5 GCM projections by Cadieux and Tremblay (unpublished).

\begin{tabular}{|c|c|c|c|c|c|c|}
\hline $\begin{array}{l}\text { Species } \\
\text { Code }\end{array}$ & Common Name & Genus & Species & Migratory Status & Trend & $\begin{array}{r}\text { Future } \\
\text { Change }\end{array}$ \\
\hline AMRE & American Redstart & Setophaga & ruticilla & Neotropical migrant & -0.071 & 0.76 \\
\hline BAWW & Black-and-white Warbler & Mniotilta & varia & Neotropical migrant & -0.226 & 0.71 \\
\hline BBWA & Bay-breasted Warbler & Dendroica & castanea & Neotropical migrant & -0.193 & -0.1 \\
\hline $\mathrm{BCCH}$ & Black-capped Chickadee & Poecile & atricapillus & Resident & 0.729 & 1.04 \\
\hline BHVI & Blue-headed Vireo & Vireo & solitarius & Short distance migrant & 3.68 & 0.3 \\
\hline BITH & Bicknell's Thrush & Catharus & bicknelli & Neotropical migrant & -5.23 & -0.44 \\
\hline BLBW & Blackburnian Warbler & Dendroica & fusca & Neotropical migrant & 0.671 & 1.32 \\
\hline BLJA & Blue Jay & Cyanocitta & cristata & Short distance migrant & 1.09 & 2.08 \\
\hline BLPW & Blackpoll Warbler & Dendroica & striata & Neotropical migrant & -4.23 & -0.44 \\
\hline $\mathrm{BOCH}$ & Boreal Chickadee & Poecile & hudsonicus & Resident & 0.261 & -0.02 \\
\hline BRCR & Brown Creeper & Certhia & americana & Short distance migrant & 0.867 & -0.05 \\
\hline BTNW & Black-throated Green Warbler & Dendroica & virens & Neotropical migrant & 0.284 & 0.84 \\
\hline CAWA & Canada Warbler & Wilsonia & canadensis & Neotropical migrant & -2.21 & 0.53 \\
\hline CEDW & Cedar Waxwing & Bombycilla & cedrorum & Short distance migrant & 0.452 & 0.55 \\
\hline CMWA & Cape May Warbler & Dendroica & tigrina & Neotropical migrant & 0.979 & -0.11 \\
\hline CONW & Connecticut Warbler & Oporornis & agilis & Neotropical migrant & -1.89 & -0.16 \\
\hline CORA & Common Raven & Corvus & $\operatorname{corax}$ & Resident & 2.54 & 0.03 \\
\hline CORE & Common Redpoll & Carduelis & flammea & Nomadic & 0.141 & -0.4 \\
\hline EVGR & Evening Grosbeak & Coccothraustes & vespertinus & Nomadic & -5.27 & 0.56 \\
\hline FOSP & Fox Sparrow & Passerella & iliaca & Short distance migrant & 0.852 & -0.45 \\
\hline GCKI & Golden-crowned Kinglet & Regulus & satrapa & Short distance migrant & -0.563 & 0.27 \\
\hline
\end{tabular}




\begin{tabular}{|c|c|c|c|c|c|c|}
\hline $\begin{array}{l}\text { Species } \\
\text { Code }\end{array}$ & Common Name & Genus & Species & Migratory Status & Trend & $\begin{array}{r}\text { Future } \\
\text { Change }\end{array}$ \\
\hline GCTH & Gray-cheeked Thrush & Catharus & minimus & Neotropical migrant & -2.65 & -0.5 \\
\hline GRAJ & Gray Jay & Perisoreus & canadensis & Resident & -0.422 & -0.25 \\
\hline HETH & Hermit Thrush & Catharus & guttatus & Short distance migrant & 0.823 & -0.07 \\
\hline LEFL & Least Flycatcher & Empidonax & minimus & Neotropical migrant & -1.58 & 0.37 \\
\hline MAWA & Magnolia Warbler & Dendroica & magnolia & Neotropical migrant & 1.13 & 0.25 \\
\hline MOWA & Mourning Warbler & Oporornis & philadelphia & Neotropical migrant & -1.23 & 1 \\
\hline NAWA & Nashville Warbler & Vermivora & ruficapilla & Neotropical migrant & 0.322 & 0.72 \\
\hline NOWA & Northern Waterthrush & Seiurus & noveboracensis & Neotropical migrant & 1.22 & -0.18 \\
\hline OCWA & Orange-crowned Warbler & Vermivora & celata & Short distance migrant & 0.722 & -0.19 \\
\hline OSFL & Olive-sided Flycatcher & Contopus & cooperi & Neotropical migrant & -2.63 & -0.1 \\
\hline OVEN & Ovenbird & Seiurus & aurocapillus & Neotropical migrant & -0.052 & 0.62 \\
\hline PAWA & Palm Warbler & Dendroica & palmarum & Short distance migrant & 4.88 & -0.52 \\
\hline PHVI & Philadelphia Vireo & Vireo & philadelphicus & Neotropical migrant & 2.46 & 0.23 \\
\hline PIGR & Pine Grosbeak & Pinicola & enucleator & Nomadic & -2.69 & -0.17 \\
\hline PISI & Pine Siskin & Carduelis & pinus & Nomadic & -2.62 & 0.27 \\
\hline PUFI & Purple Finch & Carpodacus & purpureus & Short distance migrant & -1.19 & 0.55 \\
\hline RBGR & Rose-breasted Grosbeak & Pheucticus & ludovicianus & Neotropical migrant & -0.885 & 0.91 \\
\hline RBNU & Red-breasted Nuthatch & Sitta & canadensis & Resident & 1.45 & 0.56 \\
\hline RCKI & Ruby-crowned Kinglet & Regulus & calendula & Short distance migrant & 0.551 & -0.17 \\
\hline REVI & Red-eyed Vireo & Vireo & olivaceus & Neotropical migrant & 0.832 & 0.96 \\
\hline RUBL & Rusty Blackbird & Euphagus & carolinus & Short distance migrant & -2.56 & -0.37 \\
\hline SWTH & Swainson's Thrush & Catharus & ustulatus & Neotropical migrant & -0.114 & 0.02 \\
\hline TEWA & Tennessee Warbler & Vermivora & peregrina & Neotropical migrant & 0.844 & -0.25 \\
\hline VATH & Varied Thrush & Ixoreus & naevius & Short distance migrant & -1.46 & 0.08 \\
\hline WETA & Western Tanager & Piranga & ludoviciana & Neotropical migrant & 1.45 & 0.06 \\
\hline WEWP & Western Wood-Pewee & Contopus & sordidulus & Neotropical migrant & -2 & 0.12 \\
\hline WIWA & Wilson's Warbler & Wilsonia & pusilla & Neotropical migrant & -0.486 & -0.14 \\
\hline WTSP & White-throated Sparrow & Zonotrichia & albicollis & Short distance migrant & -0.589 & 0.12 \\
\hline
\end{tabular}




\begin{tabular}{|c|c|c|c|c|c|c|}
\hline $\begin{array}{l}\text { Species } \\
\text { Code }\end{array}$ & Common Name & Genus & Species & Migratory Status & Trend & $\begin{array}{r}\text { Future } \\
\text { Change }\end{array}$ \\
\hline WWCR & White-winged Crossbill & Loxia & leucoptera & Nomadic & 1.79 & -0.29 \\
\hline YBFL & Yellow-bellied Flycatcher & Empidonax & flaviventris & Neotropical migrant & 3.21 & -0.1 \\
\hline
\end{tabular}


Appendix 3. Velocity-based macrorefugia for boreal passerine birds

Data available at: http://doi.org/10.5281/zenodo.1299880

Climate refugia - areas of species persistence under climate change - may vary in proximity to a species' current distribution, with major implications for their conservation value. Thus, the concept of climate velocity (Loarie et al. 2009) - the speed at which an organisms must migrate to keep pace with climate change - is useful to compare and evaluate refugia. Climate velocity metrics have been used to identify species and ecosystems that are most vulnerable to future climate change, as indicated by high climate velocity (Loarie et al. 2009, Burrows et al. 2011, Serra-Diaz et al. 2014). Using new methods, both forward and backward velocity can be calculated, providing complementary information about patio-temporal responses to climate change (Hamann et al. 2014, Carroll et al. 2015). In particular, backward velocity calculationsand the corresponding distance traveled to reach a given future suitable climate - can be used to identify areas of high potential refugium value for a given time period and species (Stralberg et al. 2018). Velocity-based refugia for a given species represent areas of future climatic suitability that are in close geographic proximity to currently occupied areas, i.e., where chances of rapid colonization (or persistence) in response to climate change is high.

Refugia layers were calculated for 53 forest-associated species (Table A3.1) based on spatial density models for baseline and projected future climates (Stralberg et al. 2015a, Stralberg et al. 2015b). Mean density estimates within 4-km grid cells were converted to binary estimates of suitable core habitat, defined as the grid cells where the model-predicted density exceeded the mean baseline (1961-1990) predicted density for that species within the study area (Stralberg et al. 2015a), defined here as Brandt's (2009) boreal region of North America. Core habitat predictions were then used to calculate backward biotic velocity (Carroll et al. 2015) for each species, based on four different CMIP3 (Meehl et al. 2007) global climate models (MPI ECHAM5, CCCMA CGCM3.1, GFDL CM2.1, and HadGEM1), two different time periods (2041-2070 and 2071-2100), and a high-end, business-as-usual emissions scenario (SRES A2, IPCC 2001 $)^{1}$. For each species / climate model / time period combination $i$, we calculated the distance $\left(d_{i j}\right)$ in $\mathrm{km}$ from each future distribution pixel $j$ to the nearest current distribution pixel. The assumption was that longer distances (larger backward velocity values) represented lower refugia potential, and the primary objective was to rank refugia potential by distance.

From these distance / time (velocity) layers, we applied the refugia metric described in Stralberg et al. (2018), which uses a non-linear distance decay function to down-weight larger distances, given the low probability of natural dispersal and colonization success. The decay function is based on a fat-tailed dispersal kernel, which accommodates rare long-distance tree dispersal events, and has been invoked to explain the rapid post-glacial recolonization of trees across

${ }^{1}$ CMIP3 model projections have not been shown to differ substantially in magnitude or spatial pattern from those of newer CMIP5 models (Knutti and Sedláček 2012). 
northern North America at the end of the Late Pleistocene age (Clark et al. 1998). Although birds can disperse much farther and faster due to their ability to fly, we assumed that bird dispersal would be limited by tree dispersal.

The standardized index of refugium potential, $R_{i j}$, is defined as the negative exponential portion of a fat-tailed dispersal kernel (Clark et al. 1998):

$$
R_{i j}=\exp \left(-\left|\frac{d_{i j}}{\alpha}\right|^{c}\right),
$$

where $c=0.5$ (Clark et al. 1998) and $\alpha=8.333$ (the value resulting in a mean dispersal distance of $50 \mathrm{~km}$ per century, based on the first moment of the dispersal kernel). The index has a value of 1 when $d_{i j}=0$ (i.e., for in situ refugia), rapidly declines to a value of 0.09 at $50 \mathrm{~km}$, and then slowly converges toward 0 .

For each time period, standardized refugia index values were averaged across the four GCMs to yield an ensemble index for each species. Pixels with no suitable niche space for a given GCM were converted to zero to down-weight their importance in subsequent ensemble calculations.

Two version of a multi-species index were generated: (1) an unweighted simple average across all 53 species, and (2) a version weighted by species' projected distributional responses to climate change, following methods in Stralberg et al. (2018). For the weighted multi-species refugia index, each species' ensemble refugia index was divided by the mean proportional change in total potential distribution area (future/present area) for that species (see Stralberg et al. 2015b) and then averaged across all species. For species with projected future decreases in suitable niche space, proportional change values were truncated at 0.5 , yielding a maximum weighted refugia value of 2 . For any given species, in both the weighted and unweighted versions, pixels with no suitable niche space during the baseline period or in the future under any of the four GCMs were omitted in the species averaging process so as to prevent the index from being driven primarily by species richness; zero values were assigned where suitable baseline niche space was not projected to be occupied in the future. $\mathrm{R}$ code is available on GitHub at https://github.com/dstralberg/Refugia/blob/master/StralbergEtAlGEB2018Macorefugia.Rmd.

The weighted refugia index for 53 boreal songbird species under for the 2041-2070 time period ranged from 0.032 (1st percentile) to 0.779 (99th percentile), with a median of 0.200 and an even distribution (Table A3.2). The highest weighted refugia values (99th percentile) were located in the mountains of British Columbia and along the Labrador coast; values in the 90th percentile were found throughout western mountains and in northern and eastern Quebec, and Newfoundland and Labrador (Figure A3.1a). In general, the lowest weighted refugia values (10th percentile) were found in western interior boreal regions. Weighted refugia values were lower for the 2071-2100 time period, ranging from 0.002 to 0.675 (Table A3.2) but followed similar spatial patterns (Figure A3.1b). Unweighted refugia index values ranged from 0.006 and 0.001 ( $1^{\text {st }}$ percentile) to 0.421 and 0.297 (99 ${ }^{\text {th }}$ percentile) for the 2041-2070 and 2071-2100 time 
periods, respectively (Table A3.2, Figure A3.2). The highest unweighted refugia values were found in central Ontario and Québec, and northern Newfoundland for the 2041-2070 period, but were concentrated mostly along the Labrador coast by the 2071-2100 period.

\section{References}

Brandt, J. P. 2009. The extent of the North American boreal zone. Environmental Reviews 17:101-161.

Burrows, M. T., D. S. Schoeman, L. B. Buckley, P. Moore, E. S. Poloczanska, K. M. Brander, C. Brown, J. F. Bruno, C. M. Duarte, B. S. Halpern, J. Holding, C. V. Kappel, W. Kiessling, M. I. O’Connor, J. M. Pandolfi, C. Parmesan, F. B. Schwing, W. J. Sydeman, and A. J. Richardson. 2011. The Pace of Shifting Climate in Marine and Terrestrial Ecosystems. Science 334:652-655.

Carroll, C., J. J. Lawler, D. R. Roberts, and A. Hamann. 2015. Biotic and climatic velocity identify contrasting areas of vulnerability to climate change. PLoS ONE 10:e0140486.

Clark, J. S., C. Fastie, G. Hurtt, S. T. Jackson, C. Johnson, G. A. King, M. Lewis, J. Lynch, S. Pacala, C. Prentice, E. W. Schupp, I. I. I. T. Webb, and P. Wyckoff. 1998. Reid's paradox of rapid plant migration dispersal theory and interpretation of paleoecological records. BioScience 48:13-24.

Hamann, A., D. Roberts, Q. Barber, C. Carroll, and S. Nielsen. 2014. Velocity of climate change algorithms for guiding conservation and management. Global Change Biology 21:9971004.

IPCC. 2001. Climate Change 2001. Third Assessment Report of the Intergovernmental Panel on Climate Change. Cambridge University Press, Cambridge.

Knutti, R. and J. Sedláček. 2012. Robustness and uncertainties in the new CMIP5 climate model projections. Nature Climate Change 3:369.

Loarie, S. R., P. B. Duffy, H. Hamilton, G. P. Asner, C. B. Field, and D. D. Ackerly. 2009. The velocity of climate change. Nature 462:1052-1055.

Meehl, G. A., C. Covey, T. Delworth, M. Latif, B. McAvaney, J. F. B. Mitchell, R. J. Stouffer, and K. E. Taylor. 2007. The WCRP CMIP3 multi-model dataset: a new era in climate change research. Bulletin of the American Meteorological Society 88:1383-1394.

Serra-Diaz, J. M., J. Franklin, M. Ninyerola, F. W. Davis, A. D. Syphard, H. M. Regan, and M. Ikegami. 2014. Bioclimatic velocity: the pace of species exposure to climate change. Diversity and Distributions 20:169-180.

Stralberg, D., E. M. Bayne, S. G. Cumming, P. Sólymos, S. J. Song, and F. K. A. Schmiegelow. 2015a. Conservation of future boreal forest bird communities considering lags in vegetation response to climate change: a modified refugia approach. Diversity and Distributions 21:1112-1128.

Stralberg, D., C. Carroll, J. H. Pedlar, C. B. Wilsey, D. W. McKenney, and S. E. Nielsen. 2018. Macrorefugia for North American trees and songbirds: Climatic limiting factors and multi-scale topographic influences. Global Ecology and Biogeography 27:690-703.

Stralberg, D., S. M. Matsuoka, A. Hamann, E. M. Bayne, P. Sólymos, F. K. A. Schmiegelow, X. Wang, S. G. Cumming, and S. J. Song. 2015b. Projecting boreal bird responses to climate change: the signal exceeds the noise. Ecological Applications 25:52-69. 
Table A3.1. 53 forest-associated species included in refugia index

\begin{tabular}{|c|c|}
\hline Code & Species common name (scientific name) \\
\hline AMRE & American Redstart (Setophaga ruticilla) \\
\hline BAWW & Black-and-white Warbler (Mniotilta varia) \\
\hline BBWA & Bay-breasted Warbler (Setophaga castanea) \\
\hline $\mathrm{BCCH}$ & Black-capped Chickadee (Poecile atricapillus) \\
\hline BHVI & Blue-headed Vireo (Vireo solitarius) \\
\hline BLWA & Blackburnian Warbler (Setophaga fusca) \\
\hline BLJA & Blue Jay (Cyanocitta cristata) \\
\hline BLPW & Blackpoll Warbler (Setophaga striata) \\
\hline $\mathrm{BOCH}$ & Boreal Chickadee (Poecile hudsonicus) \\
\hline BRCR & Brown Creeper (Certhia americana) \\
\hline BTNW & Black-throated Green Warbler (Setophaga virens) \\
\hline CAWA & Canada Warbler (Cardellina canadensis) \\
\hline CEDW & Cedar Waxwing (Bombycilla cedrorum) \\
\hline CMWA & Cape May Warbler (Setophaga tigrina) \\
\hline CONW & Connecticut Warbler (Oporornis agilis) \\
\hline CORA & Common Raven (Corvus corax) \\
\hline CORE & Common Redpoll (Acanthis flammea) \\
\hline DEJU & Dark-eyed Junco (Junco hyemalis) \\
\hline EVGR & Evening Grosbeak (Coccothraustes vespertinus) \\
\hline FOSP & Fox Sparrow (Passerella iliaca) \\
\hline GCKI & Golden-crowned Kinglet (Regulus satrapa) \\
\hline GCTH & Gray-cheeked Thrush (Catharus minimus) \\
\hline GRAJ & Gray Jay (Perisoreus canadensis) \\
\hline HETH & Hermit Thrush (Catharus guttatus) \\
\hline LEFL & Least Flycatcher (Empidonax minimus) \\
\hline MAWA & Magnolia Warbler (Setophaga magnolia) \\
\hline MOWA & Mourning Warbler (Geothlypis philadelphia) \\
\hline NAWA & Nashville Warbler (Oreothlypis ruficapilla) \\
\hline NOWA & Northern Waterthrush (Parkesia noveboracensis) \\
\hline OCWA & Orange-crowned Warbler (Oreothlypis celata) \\
\hline OSFL & Olive-sided Flycatcher (Contopus cooperi) \\
\hline OVEN & Ovenbird (Seiurus aurocapilla) \\
\hline PAWA & Palm Warbler (Setophaga palmarum) \\
\hline PHVI & Philadelphia Vireo (Vireo philadelphicus) \\
\hline PIGR & Pine Grosbeak (Pinicola enucleator) \\
\hline PISI & Pine Siskin (Spinus pinus) \\
\hline PUFI & Purple Finch (Carpodacus purpureus) \\
\hline RBGR & Rose-breasted Grosbeak (Pheucticus ludovicianus) \\
\hline
\end{tabular}




\begin{tabular}{ll}
\hline Code & Species common name (scientific name) \\
\hline RBNU & Red-breasted Nuthatch (Sitta canadensis) \\
RCKI & Ruby-crowned Kinglet (Regulus calendula) \\
REVI & Red-eyed Vireo (Vireo olivaceus) \\
RUBL & Rusty Blackbird (Euphagus carolinus) \\
SWTH & Swainson's Thrush (Catharus ustulatus) \\
TEWA & Tennessee Warbler (Oreothlypis peregrina) \\
VATH & Varied Thrush (Ixoreus naevius) \\
WETA & Western Tanager (Piranga ludoviciana) \\
WEWP & Western Wood-Pewee (Contopus sordidulus) \\
WIWA & Wilson's Warbler (Cardellina pusilla) \\
WIWR & Winter Wren (Troglodytes hiemalis) \\
WTSP & White-throated Sparrow (Zonotrichia albicollis) \\
WWCR & White-winged Crossbill (Loxia leucoptera) \\
YBFL & Yellow-bellied Flycatcher (Empidonax flaviventris) \\
YRWA & Yellow-rumped Warbler (Setophaga coronata) \\
\hline
\end{tabular}

Table A3.2. Percentile values of velocity-based multi-species refugia indices for 53 borealbreeding songbird species.

\begin{tabular}{lrrrrrrr}
\hline & $1 \%$ & $10 \%$ & $25 \%$ & $50 \%$ & $75 \%$ & $90 \%$ & $99 \%$ \\
\hline 2050s, weighted & 0.032 & 0.243 & 0.317 & 0.399 & 0.484 & 0.589 & 0.779 \\
2080s, weighted & 0.002 & 0.090 & 0.137 & 0.200 & 0.281 & 0.386 & 0.675 \\
2050s, unweighted & 0.006 & 0.108 & 0.159 & 0.218 & 0.292 & 0.358 & 0.421 \\
2080s, unweighted & 0.001 & 0.055 & 0.083 & 0.123 & 0.185 & 0.241 & 0.297 \\
\hline
\end{tabular}



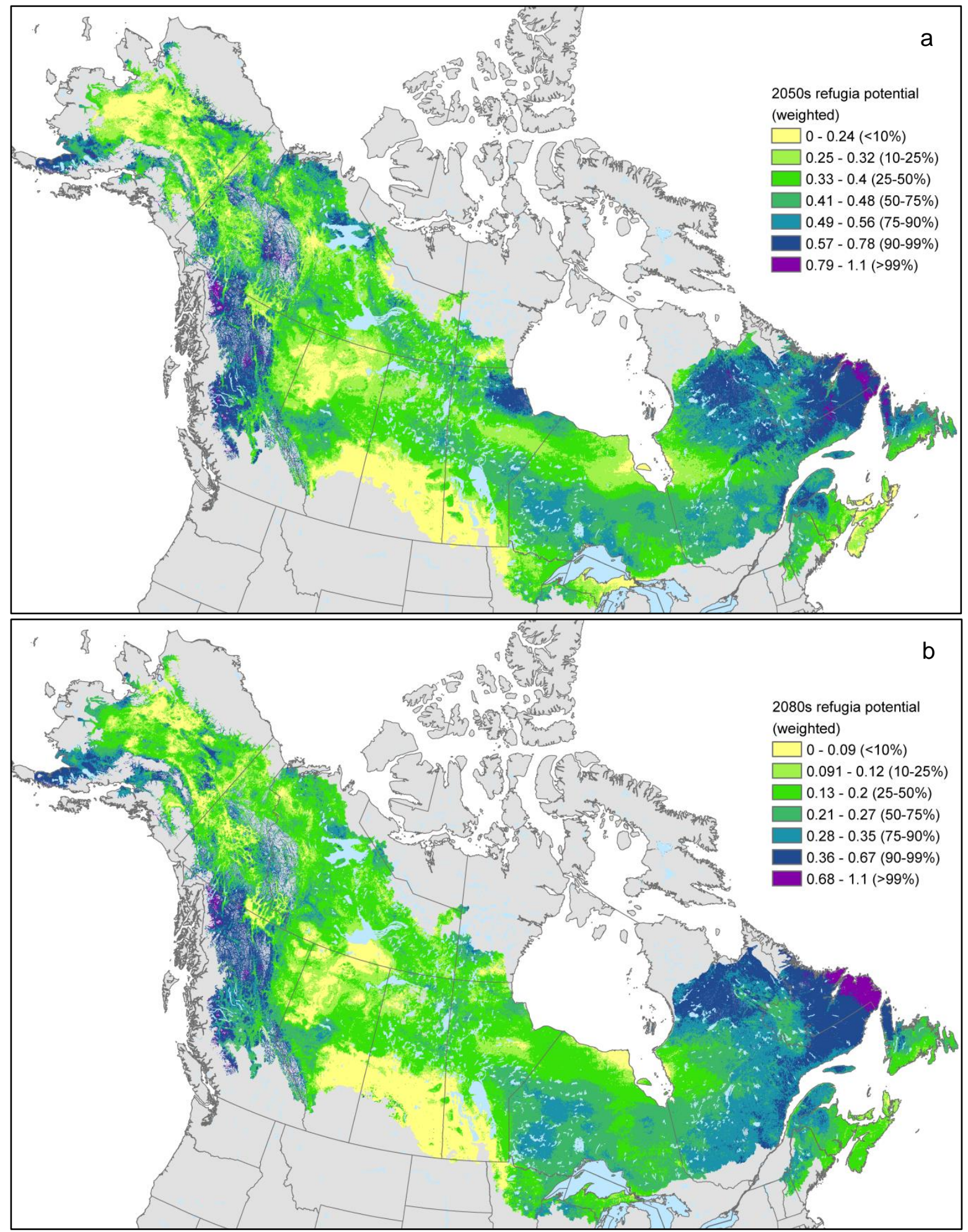

Figure A3.1. Multi-species refugia indices for (a) 2041-2070 and (b) 2071-2100, averaged across 53 forest-associated boreal-breeding species, weighted by species' projected distributional responses to climate change and mapped by percentiles. Areas covered in rock or snow/ice according to 30-m 2010 North American landcover data have been masked out. 


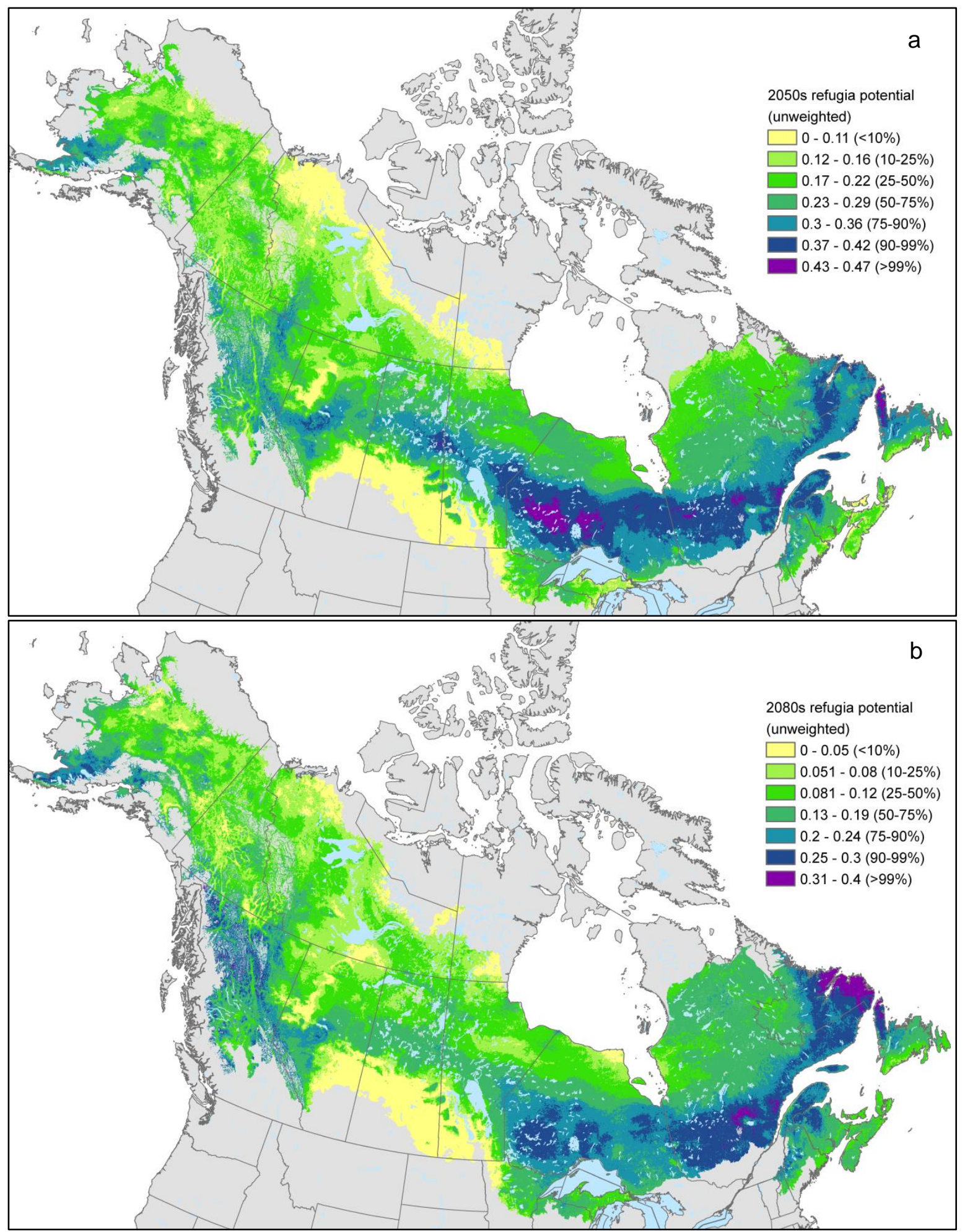

Figure A3.2. Multi-species refugia indices for (a) 2041-2070 and (b) 2071-2100, averaged across 53 forest-associated boreal-breeding species mapped by percentiles. Areas covered in rock or snow/ice according to 30-m 2010 North American landcover data have been masked out. 